\title{
A new classification of the Xanthoidea sensu lato (Crustacea: Decapoda: Brachyura) based on phylogenetic analysis and traditional systematics and evaluation of all fossil Xanthoidea sensu lato
}

\author{
Hiroaki Karasawa ${ }^{1}$, Carrie E. Schweitzer ${ }^{2}$ \\ ${ }^{1}$ Mizunami Fossil Museum, Yamanouchi, Akeyo, Mizunami, Gifu 509-6132, Japan, e-mail: GHA06103@nifty. \\ com; ${ }^{2}$ Department of Geology, Kent State University Stark Campus, 6000 Frank Ave. NW, North Canton, Ohio \\ 44720,USA, e-mail: cschweit@kent.edu
}

Key words: Crustacea, Decapoda, Brachyura, Xanthoidea, Portunidae, systematics, phylogeny

\begin{abstract}
A phylogenetic analysis was conducted including representatives from all recognized extant and extinct families of the Xanthoidea sensu lato, resulting in one new family, Hypothalassiidae. Four xanthoid families are elevated to superfamily status, resulting in Carpilioidea, Pilumnoidoidea, Eriphioidea, Progeryonoidea, and Goneplacoidea, and numerous subfamilies are elevated to family status. The Mathildellidae is moved from the Goneplacidae to the Portunoidea. Diagnoses for all superfamilies and families discussed herein are provided, embracing characters typically used by biologists as well as readily fossilized features of the dorsal carapace, sternum, abdomen, and chelipeds. All genera known from the fossil record at one time referred to the Xanthidae sensu lato, Xanthoidea sensu lato, or Goneplacidae sensu lato were evaluated as to their family level placement and as a result, the family-level placement of many of these genera has been changed herein. Balcacarcinus new substitute name, is provided herein for Bittneria Schweitzer and Karasawa, 2004.
\end{abstract}

\section{Contents}

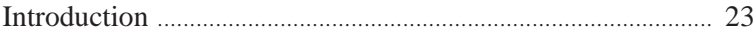

Phylogenetic analysis of the Xanthoidea sensu lato ............... 25

Material and methods …………………………………….... 25

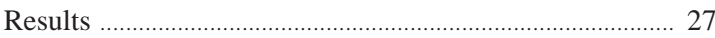

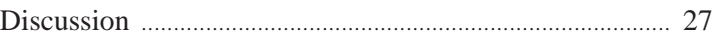

Systematic paleontology: superfamilies and families

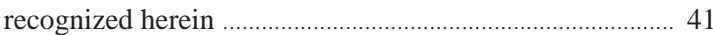

Superfamily Carpilioidea ........................................................... 42

Family Carpiliidae ........................................................... 42

Family Palaeoxanthopsidae ............................................... 43

Family Tumidocarcinidae ............................................... 44

Family Zanthopsidae .......................................................... 44

Superfamily Pilumnoidoidea .................................................... 45

Family Pilumnoididae …………………………………........ 45

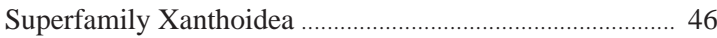

Family Domeciidae ......................................................... 46

Family Panopeidae .......................................................... 47

Genus Balcacarcinus ................................................ 47
Family Pilumnidae …................................................. 47

Family Pseudorhombilidae ……………………............. 49

Family Trapeziidae …....................................................... 49

Family Xanthidae ............................................................... 50

Superfamily Xanthoidea incertae sedis ........................... 50

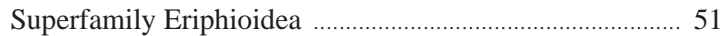

Family Platyxanthidae …………………………............. 52

Family Hypothalassiidae ................................................ 52

Family Pseudoziidae ....................................................... 53

Family Eriphiidae ……………………………............ 54

Family Oziidae …………………………………........... 54

Superfamily Progeryonoidea ……………………................. 54

Family Progeryonidae ...................................................... 54

Superfamily Goneplacoidea ................................................ 55

Family Carinocarcinoididae ......................................... 56

Family Chasmocarcinidae …........................................... 56

Family Euryplacidae ……………………………............... 57

Family Goneplacidae .................................................. 57

Family Hexapodidae ....................................................... 58

Family Trogloplacidae ................................................ 58

Superfamily Goneplacoidea incertae sedis ........................ 58

Superfamily Portunoidea ...................................................... 59

Family Carcineretidae ….................................................... 59

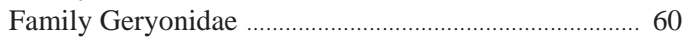

Family Mathildellidae …………………………............ 61

Family Portunidae ……………........................................ 61

The fossil record and diversity of

the Xanthoidea sensu lato ........................................................ 62

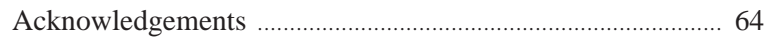

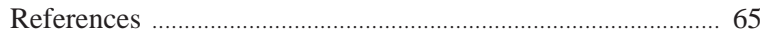

\section{Introduction}

The brachyuran superfamily Xanthoidea MacLeay, 1838, sensu lato is a large, diverse group in modern oceans, and it has a reasonably good fossil record. Beurlen (1930) first recognized the superfamily (as his subtribus) Xanthoidea containing seven families, Gecarcinidae MacLeay, 1838; Geryonidae Colosi, 
1923; Goneplacidae MacLeay, 1838; Grapsidae MacLeay, 1838; Pinnotheridae De Haan, 1833; Potamidae Ortmann, 1896; and Xanthidae MacLeay, 1838 sensu lato. In her classification of brachyurans, Guinot (1978) included eight families within the Xanthoidea: Carpiliidae Ortmann, 1893; Menippidae Ortmann, 1893; Platyxanthidae Guinot, 1977; Xanthidae; Panopeidae Ortmann, 1893; Pilumnidae Samouelle, 1819; Trapeziidae Miers, 1886; and Geryonidae. Manning and Holthuis (1981) first suggested that the Geryonidae had close affinities with the Portunidae, and subsequently, Bowman and Abele (1982) placed the Geryonidae within the Portunoidea and recognized four families within the Xanthoidea: Goneplacidae, Hexapodidae, Xanthidae, and Platyxanthidae.

Subsequently, work on the classification of the Xanthoidea has continued in earnest. Jamieson (1993) first suggested that the Xanthoidea was paraphyletic based upon spermatological evidence. Coelho and Coelho Filho (1993) considered the Xanthidae sensu lato to be polyphyletic based upon phenetic and cladistic analysis and divided it into four families: Carpiliidae; Xanthidae including the Menippinae, Platyxanthinae, Xanthinae, and Eucratopsinae; Eriphiidae; and Pilumnidae including the Trapeziinae and Pilumninae. The monophyly of the Xanthoidea was further questioned based upon additional cladistic analyses using adult morphology (Von Sternberg et al., 1999; Von Sternberg and Cumberlidge, 2001; Castro et al., 2004), foregut ossicles (Brösing, 2002), and molecular data (Schubart et al., 2000; Wetzer et al., 2003). Martin and Davis (2001) included as xanthoid families the Carpiliidae; Eumedonidae Dana, 1853; Goneplacidae; Hexapodidae Miers, 1886; Menippidae (= our Eriphiidae, see Davie [2002] and Schweitzer [2003a]); Panopeidae; Pilumnidae; Platyxanthidae; Pseudorhombilidae Alcock, 1900; Trapeziidae; and Xanthidae sensu stricto.

More recently, an additional five extant families have also been included within the Xanthoidea sensu lato: Domeciidae Ortmann, 1893; Pseudoziidae Alcock, 1898; Pilumnoididae Guinot and Macpherson, 1987; Tetraliidae Castro et al., 2004; and Trogloplacidae Guinot, 1986, (Castro et al., 2004; Davie, 2002; d'Udekem d'Acoz, 1999; Ng and Liao, 2002). Schweitzer (2003a, 2005a) recognized three extinct families: Palaeoxanthopsidae
Schweitzer, 2003a; Tumidocarcinidae Schweitzer, 2005a; and Zanthopsidae Vía, 1959.

Recent investigations have resulted in the description of new fossil and extant material, and numerous studies have revisited fossil and extant material. Thus, revisions to the systematics and classification of the currently known xanthoid families have been provided for the following families which include extant and extinct taxa: Carpiliidae, Palaeoxanthopsidae, Pseudoziidae, and Zanthopsidae (Schweitzer, 2003a); Eriphiidae, Platyxanthidae, and Tumidocarcinidae (Schweitzer, 2005a); Domeciidae and Trapeziidae (Castro et al., 2004; Schweitzer, 2005b); Goneplacidae (Karasawa and Kato, 2003a, b); Hexapodidae (Schweitzer and Feldmann, 2001); Pilumnidae (Schweitzer, 2000); and Panopeidae and Pseudorhombilidae (Schweitzer and Karasawa, 2004). These studies were performed using cladistic analysis based upon adult morphology or using proxy characters of the dorsal carapace.

Among the various families discussed above and assigned to the Xanthoidea sensu lato, the Eumedonidae has been considered to be one of the subfamilies within the Pilumnidae (Ng and Clark, 2000; Davie, 2002; Poore, 2004); we concur. We follow Schweitzer (2005b) in considering the Trapeziidae and Tetraliidae as a single family, and our analysis showing genera from each group as sisters supports her decision.

Števčić (2005) published a major revision of the brachyuran families including both fossil and extant forms, one the few such major works to do so. Among the Xanthoidea sensu lato, his revision includes numerous new subfamilies and tribes, nearly all for extant genera. He also raised some subfamilies to family status. Because our work has concentrated mainly on the fossil forms, the evaluation of each of the new subfamilies and tribes is beyond the scope of this revision, because most were erected for extant genera. Discussion of the new families and subfamilies erected for extinct taxa occur below in the appropriate systematic paleontology section. Further, such extensive splitting of the families into subfamilies and tribes, often only to embrace a single genus, seems needlessly reductionist. Such reductionism has the benefit of reflecting the variety within the Xanthoidea sensu lato, but it also can serve to obscure relationships among members of the group. In addition, we opt not to use the category 'tribe' as it seems 
arcane and is generally not used amongst the Brachyura in modern classification schemes.

The above discussion demonstrates that there has been considerable confusion over placement of taxa within the Xanthoidea, especially among those in the fossil record. The goal of the present study is to provide an adult morphology-based phylogenetic analysis of 37 taxa, including representatives of all currently-recognized families within the Xanthoidea, based upon 71 adult morphological characters. We also provide an updated list of the xanthoid genera known as fossils and document the diversity of the Xanthoidea through geological time.

\section{Phylogenetic analysis of the Xanthoidea sensu lato}

\section{Material and methods}

Thirty-seven extant and fossil taxa within the Xanthoidea sensu lato were examined. Schubart et al. (2000) showed by using partial 16S rRNA that the Eriphiidae is a sister to the Portunidae Rafinesque, 1815, and Cancridae Latreille, 1802. Von Sternberg and Cumberlidge (2001) suggested, based upon cladistic and phenetic analysis, that the Goneplacidae may be more closely related to the Portunidae than to any families of the Xanthoidea. Therefore, the analysis also includes a geryonid, Chaceon Manning and Holthuis, 1989, and seven portunid genera, including Bathynectes Stimpson, 1871; Benthochascon Alcock and Anderson, 1899; Carcinus Leach, 1814; Liocarcinus Stimpson, 1871; Necora Holthuis, 1987; Nectocarcinus A. Milne-Edwards, 1860; Raymanninus Ng, 2000; all traditionally arranged within the superfamily Portunoidea Rafinesque, 1815, as ingroup taxa to analyze the sister-group relationships of each xanthoid family.

The analyses were based upon the examination of material deposited in the Kanagawa Prefectural Museum of Natural History, Odawara, Japan; the Department of Geology, Kent State University, Kent, Ohio, U.S.A.; the Department of Marine and Environmental Sciences, The University of Ryukyus, Okinawa, Japan; the Mizunami Fossil Museum, Mizunami, Japan; the Natural History Museum and Institute, Chiba, Japan; Museu Geològic del Seminari de Barcelona (MGSB), Spain; and the Smithsonian
Institution, United States National Museum of Natural History (USNM), Washington D.C., U.S.A. The taxa examined are listed in Table 1 . If actual material was unavailable, the descriptive information for taxa was obtained from the literature. The familial and subfamilial arrangement of the genera conforms to Serène (1984), Davie (2002), Karasawa and Kato (2003a, b), Ng (1998, 2000), Ng et al. (2001), Schweitzer (2003a; 2005a, b), Schweitzer and Karasawa (2004), Karasawa and Schweitzer (2004), and Poore (2004), as well as our own observations.

The out-groups were chosen from representatives of the superfamily Cancroidea Latreille, 1802, within the heterotreme brachyurans. The Cancroidea has traditionally been regarded as a more primitive group than the Portunoidea (Balss, 1957; Guinot, 1978; Martin and Davis, 2001). Spears et al. (1992) showed that the Xanthoidea is the sister to the Cancridae and Leucosiidae Samouelle, 1819, based upon analysis of 18S rRNA. Schubart et al. (2000) indicated that the Eriphiidae (their 'Menippidae') is derived as the sister to the Cancridae and Portunidae, based upon analysis of 16S rDNA. Rice (1981) suggested that the Cancridae and Portunidae were derived from the Xanthidae sensu lato based upon zoeal evidence. Because most analyses have considered the Cancridae to be the less derived lineage, the cladogram was rooted against two genera within the Cancridae, Cancer Linnaeus, 1758, and Romaleon Gistel, 1848.

Seventy-one adult morphological characters were used in the analysis (Table 2). Those characters were mainly chosen based upon examination of previous works by Von Sternberg and Cumberlidge (2001) and Karasawa and Kato (2003a, b). The data matrix is provided in Table 3. Most characters are binary; only three have multistate character states. The missing data were scored as unknown. A presumed plesiomorphy was coded as character state '0,' and a presumed apomorphy was coded as '1.' The multiple character states $(0,1,2)$ do not indicate a transformation series. Several characters (i.e. frontal characters 2-6) may be linked as multistate characters; however, we avoided using the multistate transformation series as much as possible because we considered that each character is independent. Except for unusual preservation of Miosesarma described by Karasawa and Kato (2001), soft parts, i.e. gonopod 1, gonopod 2, are not preserved in fossil material; 
Table 1. Taxa included in the phylogenetic analysis. Classification follows that of Martin \& Davis (2001), Davie (2002), and Poore (2004), upon which the selection of taxa for our analysis was based.

Superfamily Cancroidea Latreille, 1802

Family Cancridae Latreille, 1802

Subfamily Cancrinae Latreille, 1802

Genus Cancer Linnaeus, 1758

Cancer pagurus Linnaeus, 1758

Genus Romaleon Gistel, 1848 Romaleon gibbosulus (De Haan, 1833)

Superfamily Xanthoidea MacLeay, 1838

Family Carpiliidae Ortmann, 1893

Genus Carpilius Leach in Desmarest, 1823

Carpilius maculatus (Linnaeus, 1758)

Carpilius convexus (Forskål, 1775)

Family Zanthopsidae Vía, 1959

Genus Harpactoxanthopsis Vía, 1959

Harpactoxanthopsis lutugini (Likharev, 1917)

Family Palaeoxanthopsidae Schweitzer, 2003a

Genus Lobulata Schweitzer et al., 2004 Lobulata lobulata (Feldmann et al., 1995)

Genus Paraverrucoides Schweitzer, 2003a Paraverrucoides alabamensis (Rathbun, 1935)

Genus Remia Schweitzer, 2003a Remia africana (Remy and Tessier, 1954)

Family Tumidocarcinidae Schweitzer, 2005a

Genus Pulalius Schweitzer et al., 2000 Pulalius dunhamorum Schweitzer et al., 2000

Genus Tumidocarcinus Glaessner, 1960 Tumidocarcinus giganteus Glaessner, 1960

Genus Xanthilites Bell, 1858 Xanthilites bowerbanki Bell, 1858

Family Pilumnoididae Guinot and Macpherson, 1987

Genus Pilumnoides H. Milne Edwards and Lucas, 1843

Pilumnoides perlatus (Poeppig, 1836)

Family Pilumnidae Samouelle, 1819

Subfamily Pilumninae Samouelle, 1819

Genus Pilumnus Leach, 1815 Pilumnus vespertilio (Fabricius, 1793)

Subfamily Halimedinae Alcock, 1898

Genus Halimede De Haan, 1833 Halimede ochtodes (Herbst, 1783)

Family Domeciidae Ortmann, 1893

Genus Domecia Eydoux and Souleyet, 1842 Domecia glabra Alcock, 1899

Family Trapeziidae Miers, 1886

Genus Trapezia Latreille, 1828 Trapezia cymodoce (Herbst, 1799)

Family Tetraliidae Castro et al., 2004

Genus Tetralia Dana, 1851b Tetralia glaberrima (Herbst, 1790)

Family Panopeidae Ortmann, 1893

Subfamily Panopeidae Ortmann, 1893

Genus Panopeus H. Milne Edwards, 1834

Panopeus herbstii H. Milne Edwards, 1834

Subfamily Eucratopsinae Stimpson, 1871
Genus Eucratopsis Smith, 1869 Eucratopsis crassimanus (Dana, 1851d)

Family Pseudorhombilidae Alcock, 1900

Genus Euphrosynoplax Guinot, 1969 Euphrosynoplax campechiensis Vázquez-Bader and Gracia, 1991

Family Xanthidae MacLeay, 1838

Subfamily Etisinae Ortmann, 1893

Genus Etisus H. Milne Edwards, 1834

Etisus dentatus (Herbst, 1785)

Subfamily Xanthinae MacLeay, 1838

Genus Leptodius A. Milne Edwards, 1863 Leptodius exaratus (H. Milne Edwards, 1834)

Family Platyxanthidae Guinot, 1977

Genus Platyxanthus A. Milne Edwards, 1863 Platyxanthus orbignyi (H. Milne Edwards and Lucas, 1843) Platyxanthus crenulatus A. Milne Edwards, 1879

Genus Homalaspis A. Milne Edwards, 1863 Homalaspis plana (H. Milne Edwards, 1834)

Family Pseudoziidae Alcock, 1898

Subfamily Pseudoziinae Alcock, 1898

Genus Pseudozius Dana, 1851a Pseudozius caystrus (Adams and White, 1852)

Family Eriphiidae MacLeay, 1838

Subfamily Dacryopilumninae Serène, 1984

Genus Dacryopilumnus Nobili, 1906 Dacryopilumnus rathbunae Balss, 1932

Subfamily Eriphiinae MacLeay, 1838

Genus Eriphia Latreille, 1817 Eriphia smithii MacLeay, 1838 Eriphia sebana (Shaw and Nodder, 1803)

Subfamily Menippinae Ortmann, 1893

Genus Hypothalassia Gistel, 1848 Hypothalassia armata (de Haan, 1833)

Genus Menippe De Haan, 1833 Menippe mercenaria (Say, 1818)

Genus Myomenippe Hilgendorf, 1879 Myomenippe hardwicki (Gray, 1831)

Subfamily Oziinae Dana, 1851a

Genus Epixanthus Heller, 1861 Epixanthus frontalis (H. Milne Edwards, 1834)

Genus Ozius H. Milne Edwards, 1834 Ozius guttatus H. Milne Edwards, 1834

Family Hexapodidae Miers, 1886

Genus Hexapinus Manning and Holthuis, 1981 Hexapinus sp.

Family Goneplacidae MacLeay, 1838

Subfamily Goneplacinae MacLeay, 1838

Genus Carcinoplax H. Milne Edwards, 1852 Carcinoplax indica Doflein, 1904 Carcinoplax longimanus (De Haan, 1833) Carcinoplax vestita (De Haan, 1835)

Genus Psopheticus Wood-Mason, 1892 Psopheticus hughi Rathbun, 1914 
Psopheticus stridulans Wood-Mason, 1892

Subfamily Carinocarcinoidinae Karasawa and Kato, 2003a Genus Carinocarcinoides Karasawa and Fudouji, 2000

Carinocarcinoides angustus (Karasawa, 1993)

Carinocarcinoides carinatus Karasawa and Fudouji, 2000

Subfamily Chasmocarcininae Serène, 1964

Genus Chasmocarcinus Rathbun, 1898

Chasmocarcinus typicus Rathbun, 1898

Chasmocarcinus chacei Felder and Rabalais, 1986

Subfamily Euryplacinae Stimpson, 1871

Genus Eucrate De Haan, 1835

Eucrate crenata De Haan, 1835

Genus Heteroplax Stimpson, 1858

Heteroplax nitida Miers, 1879

Subfamily Trogloplacinae Guinot, 1986

Genus Trogloplax Guinot, 1986

Trogloplax johliveti Guinot, 1986

Subfamily Mathildellinae Karasawa and Kato, 2003a

Genus Mathildella Guinot and Richer de Forges, 1981 Mathildella serrata (Sakai, 1974)

Incertae sedis

Genus Progeryon Bouvier, 1922

Progeryon guinotae Crosnier, 1976

Progeryon vaubani Guinot and Richer de Forges, 1981

Superfamily Portunoidea Rafinesque, 1815

Family Geryonidae Colosi, 1923

Genus Chaceon Manning and Holthuis, 1989

Chaceon granulatus (Sakai, 1978)

Chaceon peruvianus (d’Orbigny, 1842)

Chaceon quinquedens (Smith, 1879)

Family Portunidae Rafinesque, 1815

Subfamily Carcininae MacLeay, 1838

Genus Benthochascon Alcock and Anderson, 1899 Benthochascon hemingi Alcock and Anderson, 1899

Genus Carcinus Leach, 1814 Carcinus maenas (Linnaeus, 1758)

Genus Nectocarcinus A. Milne Edwards, 1860 Nectocarcinus tuberculosus A. Milne Edwards, 1860

Nectocarcinus bennettae Takeda and Miyake, 1969

Subfamily Polybiinae Ortmann, 1893

Genus Bathynectes Stimpson, 1871 Bathynectes maravigna (Prestandrea, 1839)

Genus Liocarcinus Stimpson, 1871 Liocarcinus corrugatus (Pennant, 1777)

Genus Necora Holthuis, 1987

Necora puber (Linnaeus, 1767)

Incertae sedis

Genus Raymanninus Ng, 2000

Raymanninus schmitti (Rathbun, 1931) therefore, the rate of missing data within examined fossil taxa is 20 to 30 per cent.

The phylogenetic analysis used PAUP* 4.0b10 (Swofford, 1999), utilizing a data matrix originating in MacClade 4.06 for OS X (Maddison and Maddison, 2003). Heuristic search analyses were performed with the following options in effect: addition sequence, 100 replications with random input order; one tree held at each step during stepwise addition; tree-bisection-reconnection (TBR) branch stepping performed; MulTrees option activated; steepest descent option not in effect; branches having maximum length zero collapsed to yield polytomies; topological constraints not enforced; tree unrooted; multistate taxa interpreted as polymorphism; character state optimization; and accelerated transformation (ACCTRAN). All characters were unordered, unscaled and equally weighted. Relative stability of clades was assessed using decay analyses (Bremer, 1994). The Bremer support was obtained using constraint trees generated in MacClade 4.06 (Maddison and Maddison, 2003) and analyzed using PAUP*.

\section{Results}

The analysis yielded two most-parsimonious trees, 239 steps long with a consistency index (CI) of 0.4017 , a retention index (RI) of 0.7534 , and a rescaled consistency index (RC) of 0.3026. A strict consensus tree of the two most-parsimonious trees is given in Figure 1. The only difference in topology of the two trees is the relative position of Progeryon. In tree one, Progeryon is the earliest-derived taxon within the 'Goneplacidae' + Hexapodidae clade, and in tree two, it is the sister to the Goneplacidae + Hexapodidae + Portunoidea clade. The relationships among the major groups, indicating Bremer support and unambiguous character state changes, are given in Figure 2.

\section{Discussion}

The monophyly of the in-group taxa, with Bremer support of 5, is well supported by five synapomorphies: the front with a median notch (2-0), the front without a median tooth (4-0), antennules folding transversely or obliquely (12-1), a distinct suture 
Table 2. Characters and their states used in the phylogenetic analysis.

1. Carapace proportion: much wider than long (0), slightly wider than long or longer than wide ( $\mathrm{L} / \mathrm{W}<0.85)(1)$

2. Front with median notch: present (0), absent (1)

3. Frontal margin: with lobes or teeth (0), nearly straight (1)

4. Median tooth on frontal margin: absent (0), present (1)

5. Front protruded anteriorly: strong (0), weak (1)

6. Notch between frontal margin and supraorbital angle: distinct (0), indistinct (1)

7. Upper orbital fissures: present (0), absent (1)

8. Anterolateral teeth: present (0), absent (1)

9. Junction between anterolateral and posterolateral margins: well marked (0), not marked (1)

10. Orbital hiatus: open (0), completely closed (1)

11. Carapace posterior carina: distinct (0), indistinct (1)

12. Antennules folding: vertically (0), obliquely or transversely (1)

13. Basal article of antenna reaching front: present (0), absent (1)

14. Antenna situated between frontal margin and supraorbital angle: present (0), absent (1)

15. Buccal frame: rectangular (0), tapered anteriorly (1)

16. Endostomial ridges: present (0), absent (1)

17. Ischium length of maxilliped 3: longer than merus:(0), shorter than merus (1)

18. Merus of maxilliped 3: subquadrate (0), suboval (1)

19. Mesial lobe ('portunid lobe') of endopod of maxilliped 1: absent (0), present (1)

20. Propodus and dactylus of endopod of maxilliped 2: separate (0), fused (1)

21. Telson of male abdomen about as long as wide (0), much longer than wide (1)

22. Male abdominal somites 4-6 much narrower than somite 3: absent (0), present (1)

23. Male abdominal somite 3 much wider than somite 4 , abdomen triangular: absent (0), present (1)

24. Male abdominal somite 3 much narrower than thoracic sternite 7: absent (0), present (1)

25. Male abdominal somites 3 and 4: distinct (0), fused (1)

26. Male abdominal somites 4 and 5: distinct (0), fused (1)

27. Male abdominal somites 3 and 4: free (0), immovable (1)

28. Male abdominal somites 4 and 5: free (0), immovable (1)

29. Sternum width: narrow (0), wide (1)

30. Sulcus delimiting sternites 3 and 4 (male): deep, well marked

31. Sulcus delimiting sternites 4 and 5 (male): complete (0), interrupted medially (1)

32. Sulcus delimiting sternites 5 and 6 (male): complete (0), interrupted medially (1)

33. Sulcus delimiting sternites 4 and 5 (female): complete (0), interrupted medially (1)

34. Sulcus delimiting sternites 5 and 6 (female): complete (0), interrupted medially (1)

35. Sulcus delimiting sternites 6 and 7: complete (0), interrupted medially (1)

36. Sulcus delimiting sternites 7 and 8: complete (0), interrupted medially (1)
37. Median groove on male sternite 3: present (0), absent (1)

38. Male sternal sutures 4-8: nearly parallel (0), not parallel (1)

39. Median sulcus on male sternite 4: present (0), absent (1)

40. Male thoracic sternites 5 with deep, median groove: absent (0), present (1)

41. Groove on male sternite 4 near lateral margin: absent (0), present (1)

42. Anterior end of male sterno-abdominal cavity: posterior on sternite 4 (0), anterior on sternite 4 (1)

43. Male sternite 8 with supplementary plate: absent (0), present (1)

44. Male sternite 8 visible ventrally: indistinct (0), distinct (1)

45. Male sternite 8 visible posteriorly: indistinct (0), distinct (1)

46. Posterolateral prolongation of male episternite 7: not marked (0), well developed (1)

47.Penial groove on male sternite 8: absent (0), present (1)

48. Fingers of pereiopod 1 dark in color: present (0), absent (1)

49. Occlusal surface of dactylus of major cheliped with molar basal tooth: absent (0), present (1)

50. Fingers of pereiopod 1 with spoon-shaped apex: absent (0), present (1)

51. Suture between merus and basis of pereiopods 1: distinct (0), indistinct (1)

52. Propodus length of pereiopods 2-4: shorter or as long as merus (0), longer than merus (1)

53. Cross section of propodi of pereiopods 2-5: cylindrical (0), laterally compressed (1)

54. Dactyli of pereiopods 2-5 with corneous tip: present (0), absent (1)

55. Dactylus of pereiopod 5: styliform (0), spatulate (1)

56. Pereiopod 5 with paddle-like dactylus: absent (0), present (1)

57.Pereiopod 5 with foliaceous propodus: absent (0), present (1)

58. Pereiopod 5: present (0), absenct (1)

59. Ambulatory dactylopropodal lock: absent (0), present (1)

60. Gonopod 1: stout (0), slender (1)

61. Gonopod 1: straight (0), slightly sinuous or curved (1), sinuous or curved (2)

62. Gonopod 1 base: slightly sinuous or straight (0), strongly curved and inflated (1)

63. Gonopod 1 with hook-shaped apex: absent (0), present (1)

64. Gonopod 1 with truncated apex: absent (0), present (1)

65. Tip of gonopod 1 : simple (0), with long hairs, spines or lobes (1)

66. Gonopod 1 with tip bearing complex lobes: absent (0), present (1)

67. Gonopod 2: long (0), short (1), very short (2)

68. Gonopod 2 shape: elongate or short but not sigmoid (0), sigmoid (1)

69. Flagellum of gonopod 2: long (0), short (1)

70. Gonopod 2 with wing-like flagellum: absent (0), present (1)

71. Tip of gonopod 2: simple (0), bifid (1) 
between male abdominal somites 4 and 5 (26-0), and the presence of a median sulcus on male thoracic sternite 4 (39-0). Transversely or obliquely folding antennules is unique.

The Xanthoidea sensu lato is shown to be paraphyletic, consisting of seven major clades, A-G. The basic family-level classification currently in use is largely supported, although some subfamilies are herein elevated to family level and the Xanthoidea sensu lato is separated into several superfamilies (Table 4). Besides the relative position of the Mathildellinae (Clade G), each Clade A-F is construed as being of superfamily status. The results are partly consistent with the topology of Von Sternberg and Cumberlidge (2001), and in-group relationships are more fully resolved than in their analysis.

The analysis suggests that Clade A (Carpiliidae + Zanthopsidae + Tumidocarcinidae + Palaeoxanthopsidae) is the sister-group to the rest of the paraphyletic Xanthoidea. This clade, with a Bremer support of 2, is united by six synapomorphies: the absence of upper orbital fissures (7-19), the absence of a posterior carapace carina (11-1), the antenna situated out of the supraorbital angle (14-1), an occlusal surface of the dactylus of the major cheliped with a molar basal tooth (49-1), cylindrical propodi of pereiopods 2-5 (53-0), and the absence of corneous tips of pereiopods 2-4 (54-1). The analysis strongly supports recognition of the Carpiliidae as a basal lineage within the Xanthoidea as suggested by Coelho and Coelho Filho (1993), Von Sternberg et al. (1999), Von Sternberg and Cumberlidge (2001), and Wetzer et al. (2003). Števčić (2005) had placed the Carpiliidae within the Eriphioidea and the Zanthopsidae and Palaeoxanthopsidae within the Xanthoidea sensu stricto, positions not supported by our analysis. The good fossil record of all four families within Clade A, one of which extends into the Cretaceous (Palaeoxanthopsidae), one of which extends into the Paleocene (Zanthopsidae), and the remainder of which extend into the Eocene, supports the basal position of this clade. Guinot (1978) and Von Sternberg and Cumberlidge (2001) suggested a sister-group relationship between the Carpiliidae and Eriphiidae; however, the analysis rejects a Carpiliidae + Eriphiidae relationship, as Coelho and Coelho Filho (1993), Von Sternberg et al. (1999), and Wetzer et al. (2003) each suggested. The Carpiliidae is basal within Clade A, followed by the Zanthopsidae, and the most derived
Palaeoxanthopsidae + Tumidocarcinidae. Within the Carpiliidae sternal sutures 4/5-7/8 of both sexes are complete, and these characters were regarded as plesiomorphic (Guinot, 1978; Števčić, 1995, 1998, 2005; Von Sternberg et al., 1999; Karasawa and Kato, 2003a). The Zanthopsidae + Palaeoxanthopsidae + Tumidocarcinidae clade lacks these plesiomorphic characters and has an incomplete sternal suture 4/5 of both sexes (characters 31 and 33).

The Pilumnoididae (Clade B) is the sister-group to the remainder of the in-group taxa. The Pilumnoididae (Clade B) and the Clades C-G + Portunoidea share three synapomorphies: the presence of a distinct suture between male abdominal somites 3 and 4 (250 ) and movable male abdominal somites 3-5 (27-0, 28-0). Guinot and Macpherson (1987) erected a new subfamily Pilumnoidinae for Pilumnoides and suggested that there is a close relationship between the Pilumnoidinae and Carpiliidae based upon thoracic sternum and cheliped characters. D’Udekem d'Acoz (1999) raised the Pilumnoidinae to full family status, whereas Davie (2002) included the Pilumnoidinae within the Goneplacidae. Most recently, Karasawa and Kato (2003b) supported the recognition of the Pilumnoididae, and suggested that the family was the sister to the Carpiliidae. However, the present analysis does not support a Carpiliidae + Pilumnoididae relationship. Števčić (2005) placed the Pilumnoididae within the Eriphioidea, which our analysis does not support. The Pilumnoididae (Clade B) lacks synapomorphies of Clade $\mathrm{A}$ and is derived as the sister to the remaining xanthoid (Clades C-G) + Portunoidea. Therefore, the analysis suggests that the Pilumnoididae warrants its own superfamily, diagnosed below.

Clade C (Xanthoidea sensu stricto) is weakly supported by only one synapomorphy (slender gonopod 1: 60-1). Clade $C$ is a sister-group to a larger clade including the Clades D-G + Portunoidea, and both Clade $\mathrm{C}$ and this larger clade are unambiguously united by six characters: medially interrupted sternal sutures 4/5 and 5/6 of both sexes (31-1, 32-1, 33-1, 34-1), the presence of a medial line on male thoracic sternite 3 (37-1), and the absence of transverse sternal sutures 4/5-7/8 (38-1). Clade C contains the Pilumnidae, Domeciidae, Trapeziidae, Tetraliinae (which we consider as part of Trapeziidae), Panopeidae, Pseudorhombilidae, and Xanthidae sensu stricto. The Pilumnidae is the sister to the remainder of Clade $\mathrm{C}$, which is supported by its Cretaceous fossil record. The 
Pilumnidae is supported by five synapomorphies, the absence of a median sulcus on male thoracic sternite 4 (39-1), the anterior end of the male sterno-abdominal cavity reaching to the anterior of thoracic sternite (42-1), a well-developed posterolateral prolongation of male episternite 7 (46-1), the presence of a hookshaped apex of gonopod 1 (63-1), and the presence of a sigmoid gonopod 2 (68-1).

The analysis supports the Domeciidae and Trape-
ziidae/Tetraliidae relationship suggested by Castro et al. (2004). Many previous works (Von Sternberg et al., 1999; Brösing, 2002; Castro et al., 2004) indicated that the Trapeziidae sensu lato is a rather advanced lineage within the polyphyletic Xanthoidea and is more closely related to 'higher' heterotremes and thoracotremes than to other xanthoids. Števčić (2005) placed the trapeziids, domeciids, and their relatives in a unique superfamily. However, our

Table 3. Input data matrix of 71 characters and 45 taxa. Missing character states are shown by “?”.

\begin{tabular}{|c|c|c|c|c|c|c|c|c|c|c|c|c|c|c|c|c|c|c|c|c|c|c|c|c|c|c|c|c|c|c|c|c|}
\hline \multirow{2}{*}{$\begin{array}{l}\text { Character } \\
\text { Taxa }\end{array}$} & \multirow{2}{*}{\multicolumn{2}{|c|}{12}} & \multirow[t]{2}{*}{3} & \multirow{2}{*}{\multicolumn{2}{|c|}{45}} & \multirow{2}{*}{\multicolumn{2}{|c|}{$\begin{array}{ll}6 & 7 \\
\end{array}$}} & & & & & & & \multirow{2}{*}{\multicolumn{4}{|c|}{51617}} & \multicolumn{3}{|c|}{181920} & 21 & & & & & & & & & & & \\
\hline & & & & & & & & & & & & & & & & & & & & & & & & & & & & & & & & \\
\hline Cancer & 0 & 1 & 0 & 1 & 0 & 0 & 0 & 0 & 0 & 0 & 0 & 0 & 0 & 0 & 0 & 0 & 0 & 0 & 0 & 0 & 0 & 0 & 0 & 0 & 1 & 1 & 1 & 1 & 0 & 1 & 0 & 0 \\
\hline Romaleon & 0 & 1 & 0 & 1 & 0 & 0 & 0 & 0 & 0 & 0 & 0 & 0 & 0 & 0 & 0 & 0 & 0 & 0 & 0 & 0 & 1 & 0 & 0 & 0 & 1 & 1 & 1 & 1 & 0 & 1 & 0 & 0 \\
\hline Palaeoxanthopsidae & 0 & 0 & 0 & 0 & 0 & 0 & $0+1$ & 0 & 0 & 0 & 0 & 1 & 0 & 1 & 0 & 0 & 0 & 0 & ? & ? & 0 & 0 & 0 & 0 & 0 & 0 & 0 & 0 & 0 & 0 & 1 & ? \\
\hline Tumidocarcinidae & $0+1$ & 0 & 0 & 0 & 0 & 0 & 1 & 0 & 0 & 0 & 1 & 1 & 0 & 0 & 0 & 0 & 0 & 0 & $?$ & ? & 0 & 0 & 0 & 0 & 0 & 0 & 0 & 0 & 0 & 0 & 1 & 1 \\
\hline Harpactoxanthopsis & & 0 & 0 & 0 & 0 & 0 & 1 & 0 & 0 & 0 & 1 & 1 & 0 & 1 & 0 & 0 & 0 & 0 & ? & ? & 0 & 0 & 0 & 0 & 1 & 1 & 1 & 1 & 0 & 0 & 1 & 0 \\
\hline Carpilius & 0 & $0+1$ & 0 & 0 & 0 & 1 & 1 & 0 & 0 & 0 & 1 & 1 & 0 & 1 & 1 & 0 & 0 & 0 & 0 & 0 & 0 & 0 & 0 & 0 & 1 & 0 & 1 & 1 & 0 & 2 & 0 & 0 \\
\hline Pilumnoides & $0+1$ & 0 & 0 & 0 & 0 & 0 & 0 & 0 & 0 & 0 & 0 & 1 & 1 & 0 & 0 & 0 & 0 & 0 & 0 & 0 & 0 & 0 & 0 & 0 & 0 & 0 & 0 & 0 & 0 & 1 & 0 & 0 \\
\hline Leptodius & 0 & 0 & 0 & 0 & 0 & 0 & 0 & 0 & 0 & 0 & 0 & 1 & 0 & 0 & 0 & 1 & 0 & 0 & 0 & 0 & 0 & 0 & 0 & 0 & 1 & 1 & 1 & 1 & 0 & 1 & 1 & 1 \\
\hline Etisus & 0 & 0 & 0 & 0 & 0 & 0 & 0 & 0 & 0 & 0 & 0 & 1 & 0 & 0 & 1 & 1 & 0 & 0 & 0 & 0 & 0 & 0 & 0 & 0 & 1 & 1 & 1 & 1 & 0 & 1 & 1 & 1 \\
\hline Panopeus & 0 & 0 & 0 & 0 & 0 & 0 & 0 & 0 & 0 & 0 & 0 & 1 & 0 & 0 & 0 & 0 & 0 & 0 & 0 & 0 & 0 & 0 & 0 & 0 & 1 & 1 & 1 & 1 & 0 & 1 & 1 & 1 \\
\hline Eucratopsis & 0 & 0 & 0 & 0 & 0 & 0 & 0 & 0 & 0 & 0 & 0 & 1 & 0 & 0 & 0 & 0 & 0 & 0 & 0 & 0 & 0 & 0 & 0 & 0 & 1 & 1 & 1 & 1 & 0 & 1 & 1 & 1 \\
\hline Euphrosynoplax & 0 & 0 & 0 & 0 & 0 & 0 & 0 & 0 & 0 & 0 & 0 & 1 & 0 & 0 & 0 & 0 & 0 & 0 & 0 & 0 & 0 & 0 & 0 & 0 & 1 & 1 & 1 & 1 & 0 & 1 & 1 & 1 \\
\hline Don & 0 & 0 & 0 & 0 & 0 & 0 & 1 & 0 & 0 & 0 & 1 & 1 & 1 & 0 & 0 & 0 & 0 & 0 & 0 & 1 & 0 & 0 & 0 & 0 & 0 & 0 & 1 & 1 & 0 & 2 & 1 & 1 \\
\hline Trapezia & 1 & 0 & 0 & 0 & 0 & 0 & 1 & 0 & 1 & 0 & 1 & 1 & 0 & 0 & 0 & 0 & 0 & 0 & 0 & 0 & 0 & 0 & 0 & 0 & 1 & 1 & 1 & 1 & 0 & 2 & 1 & 1 \\
\hline Tetralia & 1 & 1 & 1 & 0 & 0 & 1 & 1 & 1 & 1 & 0 & 1 & 1 & 0 & 0 & 0 & 0 & 0 & 0 & 0 & 0 & 0 & 0 & 0 & 0 & 0 & 0 & 1 & 1 & 0 & 2 & 1 & 1 \\
\hline Halimede & 0 & 0 & 0 & 0 & 0 & 0 & 0 & 0 & 0 & 0 & 0 & 1 & 0 & 0 & 0 & 0 & 0 & 0 & 0 & 0 & 1 & 0 & 0 & 0 & 0 & 0 & 0 & 0 & 0 & 1 & 1 & 1 \\
\hline Pilumnus & 0 & 0 & 0 & 0 & 0 & 0 & 0 & 0 & 0 & 0 & 0 & 1 & 0 & 0 & 0 & 0 & 0 & 0 & 0 & 0 & 0 & 0 & 0 & 0 & 0 & 0 & 0 & 0 & 0 & 1 & 1 & 1 \\
\hline Plat & 0 & 0 & 0 & 0 & 0 & 0 & 0 & 0 & 0 & 0 & 0 & 1 & 1 & 0 & 1 & 1 & 0 & 0 & 0 & 0 & 0 & 0 & 0 & 0 & 0 & 0 & 0 & 0 & 0 & $1+2$ & 1 & 1 \\
\hline Homalaspis & 0 & 0 & 0 & 0 & 0 & 1 & 0 & 0 & 0 & 0 & 0 & 1 & 0 & 0 & 1 & 1 & 0 & 0 & 0 & 0 & 0 & 0 & 0 & 0 & 0 & 0 & 0 & 0 & 0 & 2 & 1 & 1 \\
\hline Pseudozius & 0 & 0 & 0 & 0 & 1 & 0 & 1 & 0 & 0 & 0 & 0 & 1 & 1 & 0 & 1 & 0 & 0 & 0 & 0 & 0 & 0 & 0 & 0 & 0 & 0 & 0 & 0 & 0 & 0 & 2 & 1 & 1 \\
\hline Eriphia & 0 & 0 & 0 & 0 & 1 & 0 & 1 & 0 & 0 & 1 & 0 & 1 & 1 & 0 & 1 & 0 & 0 & 0 & 0 & 0 & 0 & 0 & 0 & 0 & 0 & 0 & 0 & 0 & 0 & 1 & 1 & 1 \\
\hline Ozius & 0 & 0 & 0 & 0 & 1 & 0 & 1 & 0 & 0 & 0 & 0 & 1 & 0 & 0 & 1 & 0 & 0 & 0 & 0 & 0 & 0 & 0 & 0 & 0 & 0 & 0 & 0 & 0 & 0 & 2 & 1 & 1 \\
\hline Epixanthus & 0 & 0 & 0 & 0 & 1 & 0 & 1 & 0 & 0 & 0 & 0 & 1 & 0 & 0 & 1 & 0 & 0 & 0 & 0 & 0 & 0 & 0 & 0 & 0 & 0 & 0 & 0 & 0 & 0 & 2 & 1 & 1 \\
\hline thalassia & 1 & 0 & 0 & 0 & 0 & 0 & 0 & 0 & 0 & 0 & 0 & 1 & 1 & 0 & 1 & 0 & 0 & 0 & 0 & 0 & 0 & 0 & 0 & 0 & 0 & 0 & 0 & 0 & 0 & 2 & 1 & 1 \\
\hline Menippe & 0 & 0 & 0 & 0 & 1 & 0 & 1 & 0 & 0 & 0 & 0 & 1 & 1 & 0 & 1 & 0 & 0 & 0 & 0 & 0 & 0 & 0 & 0 & 0 & 0 & 0 & 0 & 0 & 0 & 2 & 1 & 1 \\
\hline Myomenippe & 0 & 0 & 0 & 0 & 1 & 0 & 1 & 0 & 0 & 0 & 0 & 1 & 1 & 0 & 1 & 0 & 0 & 0 & 0 & 0 & 0 & 0 & 0 & 0 & 0 & 0 & 0 & 0 & 0 & 2 & 1 & 1 \\
\hline Dacryopilumnus & 0 & 1 & 1 & 0 & 1 & 0 & 1 & 1 & 1 & 1 & 0 & 1 & 1 & 0 & 1 & 0 & 0 & 0 & 0 & 0 & 0 & 0 & 0 & 0 & 0 & 0 & 0 & 0 & 0 & 2 & 1 & 1 \\
\hline Progeryon & 1 & 0 & $0+1$ & 0 & 0 & 0 & $0+1$ & 0 & 0 & 0 & 0 & 1 & 1 & 0 & 0 & 0 & 0 & 0 & 0 & 0 & 0 & 0 & 1 & 0 & 0 & 0 & 0 & 0 & 1 & 0 & 1 & 1 \\
\hline ldella & 0 & 0 & 1 & 0 & 0 & 0 & 0 & 0 & 0 & 0 & 0 & 1 & 1 & 0 & 0 & 0 & 0 & 0 & 0 & 0 & 0 & 0 & 1 & 0 & 0 & 0 & 1 & 1 & 1 & 2 & 1 & 1 \\
\hline Eucrate & 0 & 0 & 1 & 0 & 1 & 0 & 0 & 0 & 0 & 0 & 0 & 1 & 0 & 0 & 0 & 0 & 0 & 0 & 0 & 0 & 1 & 1 & 1 & 0 & 0 & 0 & 0 & 0 & 1 & 2 & 1 & 1 \\
\hline Heteroplax & 0 & 0 & 1 & 0 & 1 & 0 & 0 & 0 & 0 & 0 & 0 & 1 & 0 & 0 & 0 & 0 & 0 & 0 & 0 & 0 & 1 & 1 & 1 & 0 & 0 & 0 & 0 & 0 & 1 & 2 & 1 & 1 \\
\hline Carcinoplax & 0 & 1 & 1 & 0 & 1 & 1 & 1 & 0 & 0 & 0 & 0 & 1 & 1 & 1 & 0 & 0 & 0 & 0 & 0 & 0 & 0 & 0 & 1 & 0 & 0 & 0 & 0 & 0 & 1 & 2 & 1 & 1 \\
\hline Psopheticus & 0 & 1 & 1 & 0 & 1 & 1 & 1 & 0 & 0 & 0 & 0 & 1 & 1 & 1 & 0 & 0 & 0 & 0 & 0 & 0 & 0 & 0 & 1 & 0 & 0 & 0 & 0 & 0 & 1 & 2 & 1 & 1 \\
\hline Carinocarcinoides & 0 & 1 & 1 & 0 & 1 & 1 & 1 & 0 & 0 & 0 & 0 & 1 & 1 & 1 & 0 & 0 & 0 & 0 & $?$ & ? & 0 & 0 & 1 & 0 & 1 & 1 & 1 & 1 & 1 & 2 & 1 & 1 \\
\hline Chasmocarcinus & 0 & 0 & 1 & 0 & 1 & 1 & 1 & 1 & 1 & 0 & 1 & 1 & 1 & 1 & 0 & 1 & 1 & 1 & 0 & 0 & 0 & 0 & 1 & 1 & 1 & 1 & 1 & 1 & 1 & 2 & 1 & 1 \\
\hline Trogloplax & 0 & 0 & 1 & 0 & 1 & 1 & 1 & 1 & 1 & 0 & 1 & 1 & 1 & 1 & 0 & ? & 1 & 0 & 0 & $?$ & 0 & 0 & 1 & 1 & 1 & 1 & 1 & 1 & 1 & 2 & 1 & $I$ \\
\hline Hexapinus & 0 & 0 & 1 & 0 & 1 & 1 & 1 & 1 & 1 & 0 & 1 & 1 & 1 & 1 & 1 & 1 & 0 & 1 & 0 & 0 & 0 & 0 & 0 & 1 & 1 & 1 & 1 & 1 & 1 & 2 & 1 & 1 \\
\hline Chaceon & $0+1$ & 0 & 0 & 0 & 0 & 0 & $0+1$ & 0 & 0 & 0 & 0 & 1 & 0 & 1 & 0 & 0 & 0 & 0 & 0 & 0 & 0 & 0 & 1 & 0 & 0 & 0 & 1 & 1 & 1 & 1 & 1 & 1 \\
\hline Raymanninus & 0 & 0 & 0 & 0 & 0 & 0 & 0 & 0 & 0 & 0 & 0 & 1 & 0 & 1 & 0 & 0 & 0 & 0 & 0 & 0 & 0 & 0 & 1 & 0 & 0 & 0 & 1 & 1 & 1 & 1 & 1 & 1 \\
\hline Carcinus & 0 & 1 & 0 & 1 & 0 & 0 & 0 & 0 & 0 & 0 & 0 & 1 & 0 & 0 & 0 & $0+1$ & 0 & 0 & 0 & 0 & 0 & 0 & 1 & 0 & 1 & 1 & 1 & 1 & 0 & 1 & 1 & 1 \\
\hline Nectocarcinus & 1 & 0 & 0 & 0 & 0 & 0 & 0 & 0 & 0 & 0 & 0 & 1 & 1 & 0 & 0 & 0 & 0 & 0 & 0 & 0 & 0 & 0 & 1 & 0 & 0 & 0 & 1 & 1 & 0 & 1 & 1 & 1 \\
\hline Benthochascon & 1 & 1 & 0 & 1 & 0 & 0 & 0 & 0 & 0 & 0 & 0 & 1 & 1 & 0 & 0 & 0 & 0 & 0 & 1 & 0 & 0 & 0 & 1 & 0 & 0 & 0 & 1 & 1 & 0 & 1 & 1 & 1 \\
\hline Bathynectes & 0 & 0 & 0 & 0 & 0 & 0 & 0 & 0 & 0 & 0 & 0 & 1 & 0 & 0 & 0 & 0 & 0 & 0 & 1 & 0 & 0 & 0 & 1 & 0 & 0 & 0 & 1 & 1 & 1 & 1 & 1 & 1 \\
\hline Necora & 0 & 0 & 0 & 0 & 0 & 0 & 0 & 0 & 0 & 0 & 0 & 1 & 0 & 0 & 0 & 0 & 0 & 0 & 1 & 0 & 0 & 0 & 1 & 0 & 1 & 1 & 1 & 1 & 1 & 1 & 1 & 1 \\
\hline Liocarcinus & 1 & 1 & 0 & 1 & 0 & 0 & 0 & 0 & 0 & 0 & 0 & 1 & 0 & 0 & 0 & 0 & 0 & 0 & 1 & 0 & 0 & 0 & 1 & 0 & 1 & 1 & 1 & 1 & 0 & 1 & 1 & 1 \\
\hline
\end{tabular}


analysis does not support these contentions. The domeciid + trapeziid + tetraliine clade is derived as the sister to the panopeid + pseudorhombilid + xanthid clade (Jamieson, 1993; Schubart et al., 2000; Von Sternberg and Cumberlidge, 2001).

The Eucratopsinae, previously assigned to the Goneplacidae, was moved to the Panopeidae (Guinot, 1978; Martin and Abele, 1986; Schweitzer and Karasawa, 2004; Števčić, 2005), whereas Williams
(1984) and Sakai (2004) retained the subfamily within the Goneplacidae. Hendrickx (1998) treated the Pseudorhombilinae, formerly included in the Goneplacidae, as a distinct family. Sakai (2004) synonymised the subfamily with the goneplacid Carcinoplacinae. In the present analysis, both the Eucratopsinae and Pseudorhombilinae are excluded from the Goneplacidae and are placed within the Xanthoidea sensu stricto (Clade C), and we concur

$\begin{array}{llllllllllllllllllllllllllllllllllllllll}0 & 0 & 0 & 0 & 0 & 0 & 1 & 0 & 0 & 1 & 0 & 0 & 0 & 0 & 0 & 0 & 0 & 0 & 0 & 0 & 1 & 0 & 0 & 0 & 0 & 0 & 0 & 0 & 0 & 0 & 0 & 0 & 0 & 0 & 0 & 0 & 1 & 0 & 0\end{array}$

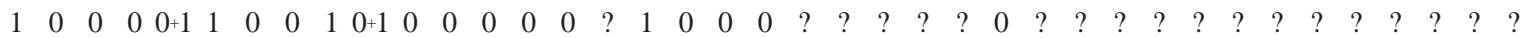

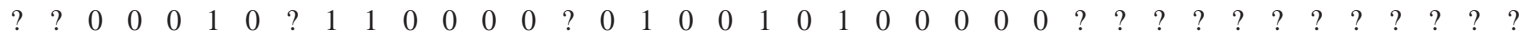

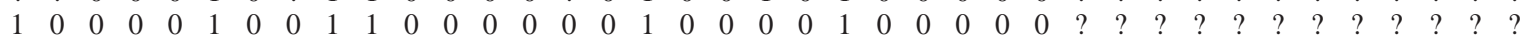
$\begin{array}{lllllllllllllllllllllllllllllllllllllllll}0 & 0 & 0 & 0 & 1 & 0 & 0 & 0 & 0 & 0 & 0 & 0 & 0 & 0 & 0 & 0 & 1 & 0 & 1 & 0 & 0 & 1 & 0 & 0 & 0 & 0 & 0 & 0 & 1 & 0 & 0 & 0 & 0 & 0 & 0 & 0 & 0 & 1 & 0\end{array}$

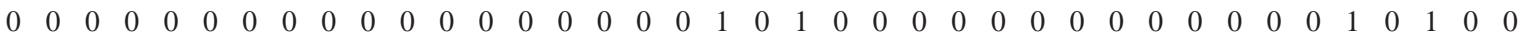
$\begin{array}{lllllllllllllllllllllllllllllllllllllllll}1 & 1 & 0 & 0 & 1 & 1 & 0 & 0 & 0 & 0 & 0 & 0 & 0 & 0 & 0 & 0 & 0 & 1 & 0 & 0 & 1 & 0 & 0 & 0 & 0 & 0 & 0 & 1 & 1 & 0 & 0 & 0 & 1 & 0 & 1 & 0 & 1 & 0 & 0\end{array}$

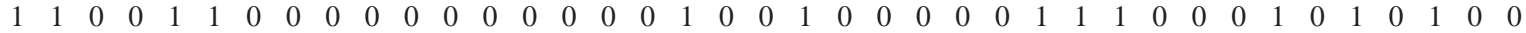

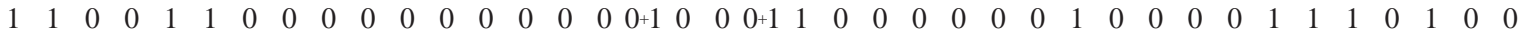

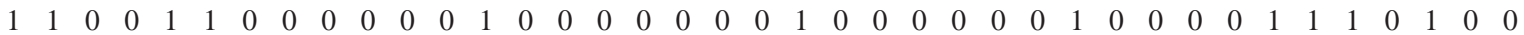

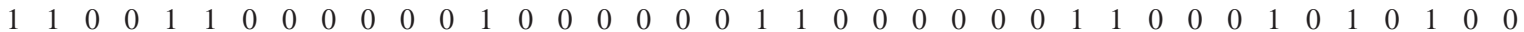
$\begin{array}{llllllllllllllllllllllllllllllllllllllll}1 & 1 & 0 & 0 & 1 & 1 & 0 & 0 & 0 & 0 & 0 & 0 & 0 & 0 & 0 & 0 & 0 & 0 & 0 & 0 & 1 & 0 & 0 & 0 & 0 & 0 & 1 & 1 & 0 & 0 & 0 & 0 & 0 & 0 & 1 & 0 & 1 & 0 & 0\end{array}$

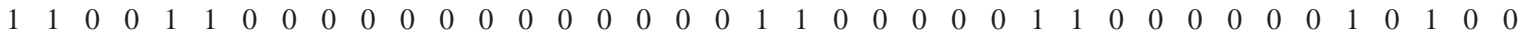
$\begin{array}{llllllllllllllllllllllllllllllllllllllllll}1 & 1 & 0 & 0 & 1 & 1 & 0 & 0 & 0 & 0 & 0 & 0 & 0 & 0 & 0 & 0 & 0 & 0 & 0 & 1 & 1 & 0 & 0 & 0 & 0 & 0 & 1 & 1 & 0 & 0 & 0 & 0 & 0 & 0 & 1 & 0 & 1 & 0 & 0\end{array}$ $\begin{array}{lllllllllllllllllllllllllllllllllllllllll}1 & 1 & 0 & 0 & 1 & 1 & 1 & 0 & 1 & 1 & 0 & 0 & 0 & 1 & 0 & 0 & 0 & 0 & 0 & 0 & 1 & 0 & 0 & 0 & 0 & 0 & 0 & 1 & 0 & 0 & 1 & 0 & 1 & 0 & 2 & 1 & 1 & 0 & 0\end{array}$

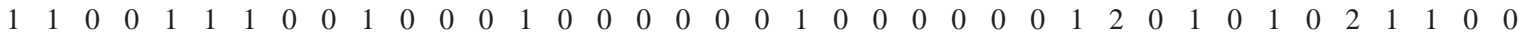

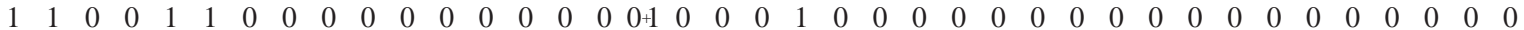
$\begin{array}{llllllllllllllllllllllllllllllllllllllll}1 & 1 & 0 & 0 & 1 & 1 & 0 & 0 & 0 & 0 & 0 & 0 & 0 & 0 & 0 & 0 & 0 & 0 & 0 & 0 & 1 & 0 & 0 & 0 & 0 & 0 & 0 & 0 & 0 & 0 & 0 & 0 & 0 & 0 & 0 & 0 & 0 & 0 & 0\end{array}$ $\begin{array}{lllllllllllllllllllllllllllllllllllllllll}1 & 1 & 0 & 0 & 1 & 1 & 0 & 0 & 0 & 0 & 0 & 0 & 0 & 0 & 0 & 0 & 1 & 0 & 0 & 0 & 1 & 0 & 0 & 0 & 0 & 0 & 0 & 1 & 0 & 0 & 0 & 0 & 0 & 0 & 1 & 0 & 1 & 0 & 0\end{array}$

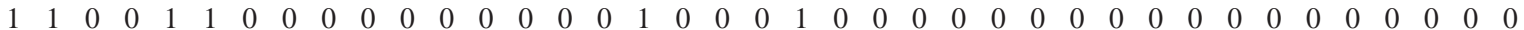
$\begin{array}{llllllllllllllllllllllllllllllllllllllll}1 & 1 & 0 & 0 & 1 & 1 & 0 & 0 & 0 & 0 & 0 & 0 & 0 & 0 & 0 & 0 & 1 & 0 & 0 & 0 & 1 & 0 & 0 & 0 & 0 & 0 & 0 & 0 & 0 & 0 & 0 & 0 & 0 & 0 & 0 & 0 & 0 & 1 & 0\end{array}$ $\begin{array}{lllllllllllllllllllllllllllllllllllllllll}1 & 1 & 0 & 0 & 1 & 1 & 0 & 0 & 0 & 0 & 0 & 0 & 0 & 0 & 0 & 0 & 1 & 0 & 0 & 0 & 1 & 0 & 0 & 0 & 0 & 0 & 0 & 0 & 0 & 0 & 0 & 0 & 0 & 0 & 0 & 0 & 0 & 1 & 0\end{array}$ $\begin{array}{llllllllllllllllllllllllllllllllllllllll}1 & 1 & 0 & 0 & 1 & 1 & 0 & 0 & 0 & 0 & 0 & 0 & 0 & 0 & 0 & 0 & 1 & 0 & 0 & 0 & 1 & 0 & 0 & 0 & 0 & 0 & 0 & 0 & 0 & 0 & 0 & 0 & 0 & 0 & 0 & 0 & 0 & 0 & 0\end{array}$ $\begin{array}{llllllllllllllllllllllllllllllllllllllll}0 & 0 & 0 & 0 & 1 & 1 & 0 & 1 & 0 & 0 & 0 & 0 & 0 & 0 & 0 & 0 & 1 & 0 & 0 & 0 & 1 & 0 & 0 & 0 & 0 & 0 & 0 & 0 & 0 & 0 & 0 & 0 & 0 & 0 & 0 & 0 & 0 & 1 & 0\end{array}$

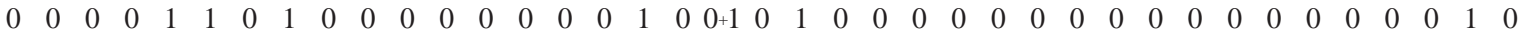
$\begin{array}{llllllllllllllllllllllllllllllllllllllll}0 & 0 & 0 & 0 & 1 & 1 & 0 & 0 & 0 & 0 & 0 & 0 & 0 & 0 & 0 & 0 & 0 & 0 & 1 & 0 & 1 & 0 & 0 & 0 & 0 & 0 & 0 & 0 & 0 & 0 & 0 & 0 & 0 & 0 & 0 & 0 & 0 & 1 & 0\end{array}$ $\begin{array}{llllllllllllllllllllllllllllllllllllllllllllllllll}1 & 1 & 1 & 1 & 1 & 1 & 0 & 0 & 0 & 0 & 0 & 0 & 0 & 0 & 0 & 0 & 1 & 0 & 0 & 1 & 1 & 0 & 0 & 0 & 0 & 0 & 0 & 0 & 0 & 0 & 0 & 0 & 0 & 0 & 0 & 0 & 0 & 0 & 0\end{array}$ $\begin{array}{llllllllllllllllllllllllllllllllllllllll}1 & 1 & 1 & 0 & 1 & 1 & 1 & 0 & 0 & 0 & 0 & 0 & 0 & 0 & 0 & 0 & 0 & 0 & 0 & 1 & 1 & 0 & 1 & 0 & 0 & 0 & 0 & 0 & 2 & 1 & 0 & 0 & 0 & 0 & 0 & 0 & 0 & 0 & 0\end{array}$ $\begin{array}{lllllllllllllllllllllllllllllllllllllllll}1 & 1 & 1 & 1 & 1 & 1 & 1 & 0 & 0 & 1 & 0 & 0 & 0 & 1 & 0 & 1 & 0 & 0 & 0 & 1 & 1 & 1 & 0 & 0 & 0 & 0 & 0 & 1 & 1 & 0 & 0 & 0 & 0 & 0 & 2 & 0 & 1 & 0 & 0\end{array}$ $\begin{array}{lllllllllllllllllllllllllllllllllllllllll}1 & 1 & 1 & 1 & 1 & 1 & 1 & 0 & 0 & 1 & 0 & 0 & 1 & 1 & 0 & 1 & 0 & 0 & 0 & 1 & 1 & 1 & 0 & 0 & 0 & 0 & 0 & 1 & 1 & 0 & 0 & 0 & 0 & 0 & 2 & 0 & 1 & 0 & 0\end{array}$

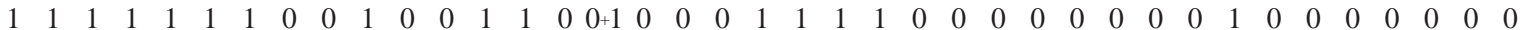
$\begin{array}{lllllllllllllllllllllllllllllllllllllllll}1 & 1 & 1 & 1 & 1 & 1 & 1 & 0 & 0 & 1 & 0 & 0 & 1 & 1 & 0 & 1 & 0 & 0 & 0 & 1 & 1 & 1 & 0 & 0 & 0 & 0 & 0 & 0 & 0 & 0 & 0 & 1 & 0 & 0 & 0 & 0 & 0 & 0 & 0\end{array}$

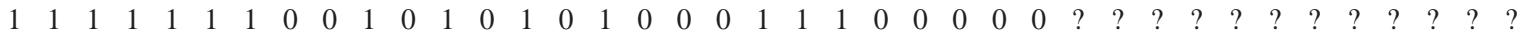

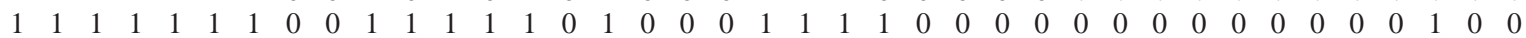
$\begin{array}{lllllllllllllllllllllllllllllllllllllll}1 & 1 & 1 & 1 & 1 & 1 & 1 & 0 & 0 & 1 & 1 & 1 & 1 & 1 & 0 & 1 & 0 & 0 & 0 & 1 & 1 & 1 & 0 & 0 & 0 & 0 & 0 & 0 & 0 & 0 & 0 & 0 & 0 & 0 & 0 & 0 & 0 & 0 & 0\end{array}$ $\begin{array}{lllllllllllllllllllllllllllllllllllllllll}1 & 1 & 1 & 1 & 1 & 1 & 1 & 0 & 0 & 1 & 0 & 0 & 0 & 1 & 0 & 1 & 0 & 0 & 0 & 0 & 1 & 0 & 0 & 0 & 0 & 1 & 0 & 0 & 0 & 0 & 0 & 0 & 0 & 0 & 1 & 0 & 1 & 0 & 0\end{array}$

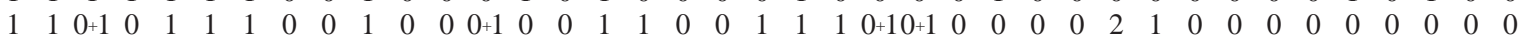
$\begin{array}{llllllllllllllllllllllllllllllllllllllll}1 & 1 & 1 & 1 & 1 & 1 & 1 & 0 & 0 & 1 & 0 & 1 & 0 & 1 & 1 & 1 & 1 & 0 & 0 & 1 & 1 & 1 & 1 & 0 & 0 & 0 & 0 & 0 & 2 & 1 & 0 & 0 & 0 & 0 & 0 & 0 & 0 & 0 & 0\end{array}$ $\begin{array}{llllllllllllllllllllllllllllllllllllllll}1 & 1 & 1 & 0 & 1 & 1 & 1 & 0 & 0 & 1 & 0 & 1 & 0 & 1 & 1 & 1 & 0 & 0 & 0 & 1 & 1 & 1 & 1 & 0 & 0 & 0 & 0 & 0 & 2 & 1 & 0 & 0 & 0 & 0 & 1 & 0 & 1 & 0 & 1\end{array}$ $\begin{array}{llllllllllllllllllllllllllllllllllllllll}1 & 1 & 0 & 0 & 1 & 1 & 1 & 0 & 0 & 1 & 0 & 1 & 0 & 1 & 1 & 1 & 0 & 0 & 0 & 1 & 1 & 1 & 1 & 1 & 1 & 0 & 0 & 0 & 1+2 & 1 & 0 & 0 & 0 & 0 & 0 & 0 & 0 & 0 & 0\end{array}$ $\begin{array}{lllllllllllllllllllllllllllllllllllllll}1 & 1 & 1 & 1 & 1 & 1 & 1 & 0 & 0 & 1 & 0 & 1 & 0 & 1 & 1 & 1 & 1 & 0 & 0 & 1 & 1 & 1 & 1 & 1 & 1 & 0 & 0 & 0 & 2 & 1 & 0 & 0 & 0 & 0 & 0 & 0 & 0 & 0 & 0\end{array}$ $\begin{array}{llllllllllllllllllllllllllllllllllllllll}1 & 1 & 1 & 1 & 1 & 1 & 1 & 0 & 0 & 1 & 0 & 1 & 0 & 1 & 1 & 1 & 1 & 0 & 0 & 1 & 1 & 1 & 1 & 1 & 1 & 0 & 0 & 0 & 2 & 1 & 0 & 0 & 0 & 0 & 0 & 0 & 1 & 0 & 1\end{array}$ $\begin{array}{llllllllllllllllllllllllllllllllllllllllllll}1 & 1 & 1 & 1 & 1 & 1 & 1 & 0 & 0 & 1 & 0 & 1 & 0 & 1 & 1 & 1 & 1 & 0 & 0 & 1 & 1 & 1 & 1 & 1 & 1 & 0 & 0 & 0 & 2 & 1 & 0 & 0 & 0 & 0 & 1 & 0 & 1 & 0 & 1\end{array}$ $\begin{array}{lllllllllllllllllllllllllllllllllllllllll}1 & 1 & 1 & 1 & 1 & 1 & 1 & 0 & 0 & 1 & 0 & 1 & 0 & 1 & 1 & 1 & 0 & 0 & 0 & 1 & 1 & 1 & 1 & 1 & 1 & 0 & 0 & 0 & 2 & 1 & 0 & 0 & 0 & 0 & 1 & 0 & 1 & 0 & 1\end{array}$ 
with Hendrickx (1998) and Števčić (2005) in considering the Pseudorhombilidae as a family. We follow Schweitzer and Karasawa (2004) in placing the Eucratopsinae in the Panopeidae.

Hendrickx (1998) previously had noted that the relationship between the Pseudorhombilidae and Panopeidae was difficult to establish. A sister-group relationship between the Panopeidae and Xanthidae has been suggested by previous studies (Coelho and Coelho Filho, 1993; Von Sternberg et al., 1999), and our analysis supports this finding, suggesting the monophyly of the Panopeidae, containing the Eucratopsinae and Panopeinae and with the Panopeidae as a basal clade, followed by the more derived Pseudorhombilidae + Xanthidae sensu stricto clade.

Clade D (Platyxanthidae + Hypothalassiidae + Eriphiidae + Oziidae + Pseudoziidae) stands as the sister to Clades E-F (Goneplacidae + Hexapodidae) + Portunoidea. Clade D is weakly supported by only one character, an anteriorly tapered buccal frame (15-1). Two synapomorphies, an indistinct sternal suture 3/4 (30-2) and a long gonopod 2 (69-0), unite Clade D and the larger clade including Clades E-F + Portunoidea. Guinot (1978) had previously suggested that there was a close relationship between the Platyxanthidae and Eriphiidae, and Karasawa and Kato (2003a, b) had suggested that the Eriphiidae was the sister to the Pseudoziidae. Schweitzer (2005a) mentioned that the Carpiliidae, Zanthopsidae, Eriphiidae, Platyxanthidae, and Tumidocarcinidae comprise a natural group and might warrant their own superfamily. The analysis supports a Platyxanthidae + Eriphiidae + Pseudoziidae relationship, but the relationship of these three families together with the Carpiliidae and Zanthopsidae is not supported. Števčić (2005) erected the superfamily Pseudozioidea for the Pseudoziidae and Flindersoplacidae Števčić, 2005, but our analysis does not support its superfamily status.

Hypothalassia is the sister-group of an unresolved polytomy consisting of the Pseudoziidae, Eriphiidae, and Oziidae. Hypothalassia lacks two synapomorphies, a weakly protruded front (5-1) and the absence of the upper orbital fissures (7-1), of the clade (Pseudoziidae + remaining members of Eriphiidae); therefore, it cannot be placed within the previously recognized eriphiid subfamilies. As a result, a new family is herein erected for Hypothalassia.

In the present analysis, the sister-group relation- ship of the clade (Pseudoziidae + Eriphiidae + (Oziinae + Dacryopilumninae + Menippinae)) is unresolved; however, the Eriphiidae lack a synapomorphy (a long, filamentous gonopod 2: 70-1) of the monophyletic clade (Oziinae + Dacryopilumninae + Menippinae). The analysis suggests that the Eriphiidae containing the sole genus Eriphia be treated as a distinct family, which Coelho and Coelho Filho (1993), Guinot et al. (2002), and Ng and Clark (pers. comm. in Davie, 2002) have already suggested.

The monophyly of the clade (Oziinae + Dacryopilumninae + Menippinae) is supported by only one synapomorphy (70-1); even so, the Oziidae Dana, 1851a, i.e. Guinot et al. (2002), is considered to be a valid taxon and three subfamilies, Oziinae, Dacryopilumninae, and Menippinae, are here placed within it. The Oziinae is the sister to the Dacryopilumninae and Menippinae, and the Dacryopilumninae is derived as the sister to the Menippinae sensu stricto. The Dacryopilumninae is characterized by seven characters: the absence of a median notch on the frontal margin (2-1), the absence of frontal teeth (3-1), the absence of anterolateral teeth (8-1, 9-1), a completely closed orbital hiatus (10-1), the absence of a large molar tooth on the occlusal surface of the major cheliped (49-0), and the presence of the cheliped merus fused to the basis-ischium (51-1). The Menippinae is defined by one unique synapomorphy, a deep medial hollow on male thoracic sternite 5 (40-1). Ng et al. (2001) and Davie (2002) did not consider the Menippinae to be synonymous with the Oziinae, with which we concur. We also note that within the Eriphioidea, sternal sutures as well as features of the carapace, antennae, orbits, and gonopod 2 (Ng et al., 2001; Davie, 2002) are supported as useful phylogenetic characters. In the Hypothalassiidae, the Eriphiidae, and the Oziinae of the Oziidae, sternal sutures $4 / 5$ and $5 / 6$ of both sexes are incomplete, whereas in the Dacryopilumninae and Menippinae of the Oziidae, sutures 4/5 and 5/6 of females

Fig. 1. Strict consensus tree of two most-parsimonious trees of 45 taxa. Length $=239$, Consistency index $=0.4017$, Retention index $=0.7534$, Rescaled consistency index $=0.3026$. Bremer support of each clade is indicated. Genera, subfamilies, families, and superfamilies listed at right follow the classification largely in the sense of Martin and Davis (2001), Davie (2002), and Poore (2004), reflecting the classification used to generate our list of included taxa. 


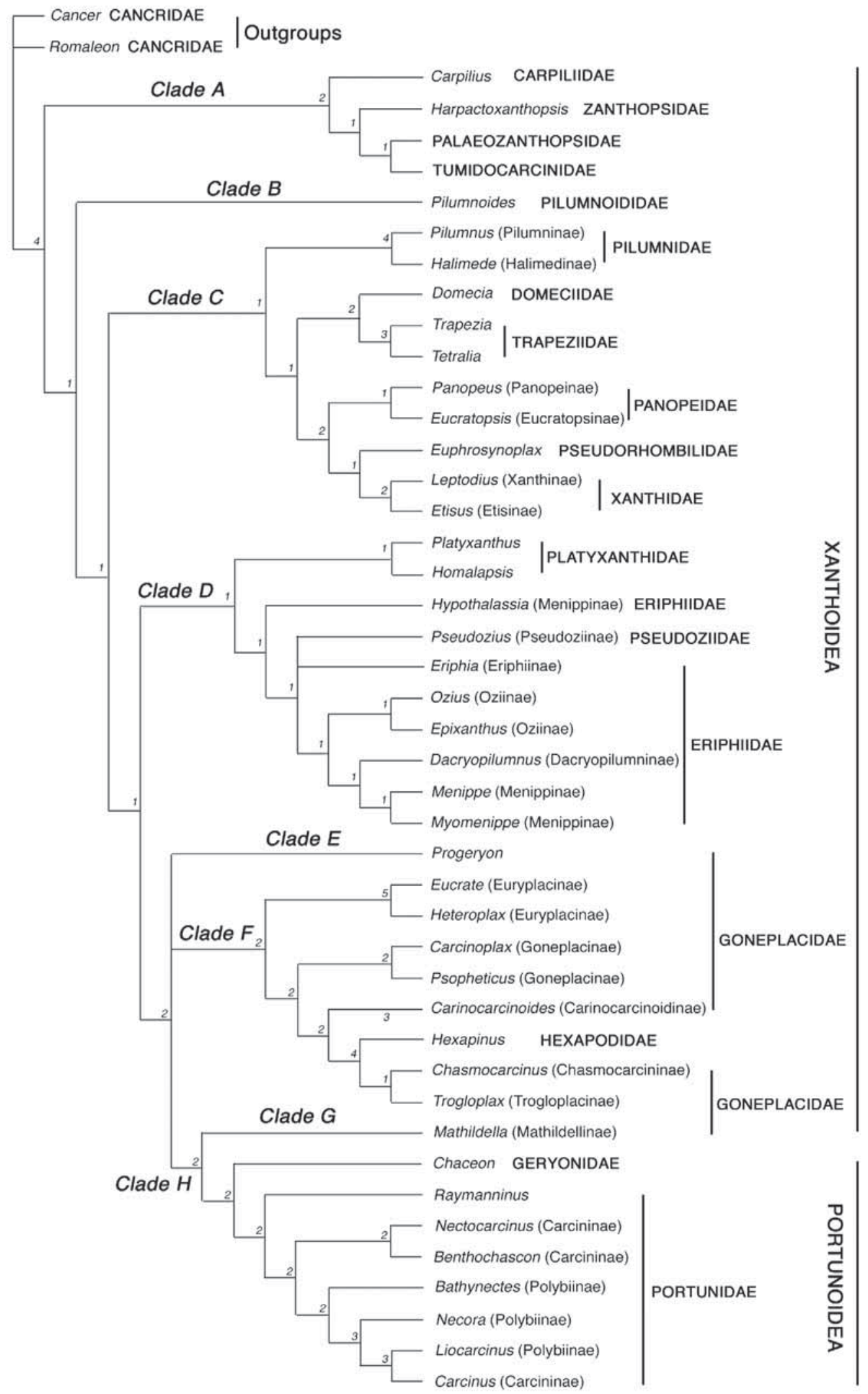




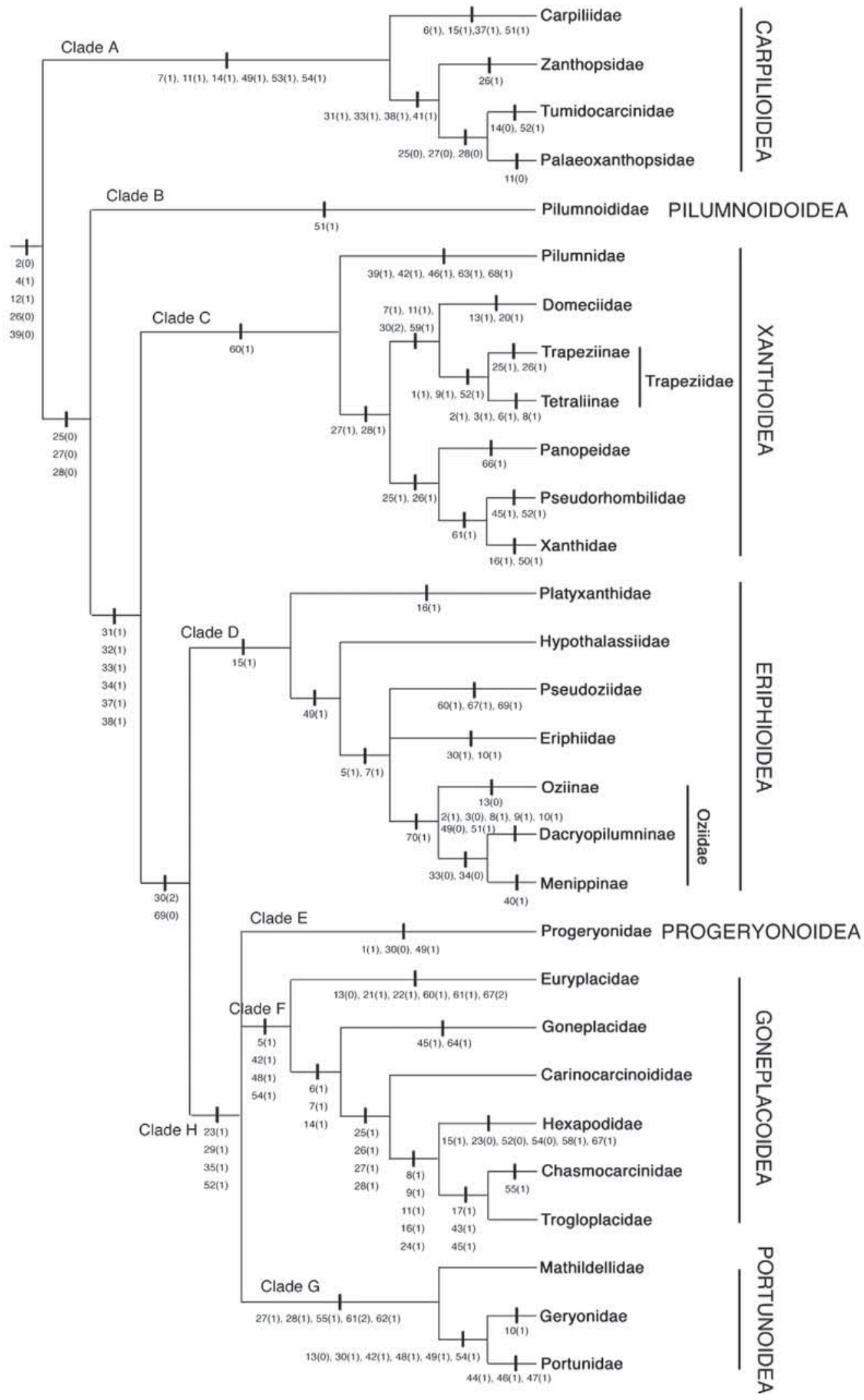


are complete and in males are incomplete.

Clade H (Progeryonoidea + Goneplacoidea + Portunoidea), with Bremer support of 2, is unambiguously united by four synapomorphies: a broadly triangular male abdomen (23-1), a wide thoracic sternum (29-1), a medially interrupted sulcus delimiting thoracic sternites 6 and 7 (35-1), and relatively long propodi of pereiopods 2-5 (52-1). The sistergroup relationships within Clade $\mathrm{H}$ cannot be resolved as it is a polytomy. Karasawa and Kato (2003a, b) considered that the Goneplacidae was monophyletic based upon cladistic analysis; however, the present analysis suggests that the Goneplacidae sensu Karasawa and Kato is paraphyletic. The Portunoidea clade, with Bremer support of 2, is well defined by five synapomorphies: fused, immovable male abdominal somites 3-5 (27-1, 28-1); a spatulate dactylus of pereiopods 5 (55-1); strongly curved gonopods 1 (61-2); and the presence of a strongly curved, inflated base of gonopods 1 (62-1). The Mathildellidae, which had been considered by Karasawa and Kato (2003a) to be a goneplacid, is derived earliest within the clade, followed by the Geryonidae and Portunidae.

In previous work, the systematic placement of Progeryon has been variable. Bouvier (1922) originally placed Progeryon together with Geryon Krøyer, 1837, within his Galenidae. Balss (1957) and Guinot (1970 [1971]) assigned the genus to the Geryonidae; however, Manning and Holthuis (1981) questioned their opinions. Manning and Holthuis (1989) later suggested that Progeryon and Paragalene Kossmann, 1878, previously assigned to the Geryonidae, might well belong to a new family. Poupin (1996) and D’Udekem d'Acoz (1999) included Progeryon within the Xanthoidea, but did not place it into a family. Ng and Guinot (1999) suggested that Progeryon is a member of the goneplacid Carcinoplacinae. Most recently, Poupin (2003) included Progeryon within the Goneplacidae, but Karasawa and Kato (2003b) showed that Progeryon cannot be assigned to the Goneplacinae sensu Karasawa and Kato (2003a) (=

Fig. 2. Strict consensus tree of two most-parsimonious trees of 43 taxa within the Xanthoidea sensu lato and Portunoidea. Length $=239$, Consistency index $=0.4017$, Retention index $=0.7534$, Rescaled consistency index $=0.3026$. Unambiguous Character state changes are given. Families and superfamilies at right reflect the new classification scheme proposed herein.
Carcinoplacinae) and did not place it within any goneplacid subfamily. Števčić (2005) placed the genus within a tribe of the Geryonidae. The present analysis suggests that Progeryon warrants its own superfamily and family because the genus lacks the synapomorphies of Clade F (Goneplacidae + Hexapodidae) and the Portunoidea.

Clade F contains five subfamilies of the Goneplacidae, as well as the Hexapodidae, and, with Bremer support of 2, is well defined by five synapomorphies: a weakly protruded front (5-1), the anterior end of the male sterno-abdominal cavity reaching to the anterior thoracic sternite 4 (42-1), a well-developed posterolateral prolongation of male thoracic episternite 7 (46-1), the absence of dark-colored cheliped fingers (48-1), and the absence of corneous tips of the dactyli of pereiopods 2-5 (54-1). Within the clade, the Chasmocarcininae and Trogloplacinae are sister taxa nested as the most derived clade, preceded by the Hexapodidae, Carinocarcinoidinae, Goneplacinae, and the most basal Euryplacinae.

The monophyly of the Euryplacinae, with Bremer support of 4, is well supported by six synapomorphies: the presence of the basal article of the antenna reaching the front (13-0), the possession of a long telson (21-1), distinctly narrow male abdominal somites 4-6 (22-1), a slender, slightly curved gonopod 1 (60-1, 61-1), and a very short gonopod 2 (672 ). The Goneplacinae, with a Bremer support of 2, share two synapomorphies, thoracic sternite 8 visible posteriorly (45-1) and the possession of a truncated apex of gonopod 1 (64-1). The Carinocarcinoidinae + Hexapodidae + Chasmocarcininae + Trogloplacinae clade, with Bremer support of 3 , is well united by four characters: the possession of completely fused, immovable male thoracic sternites 3-5 (25-1, 26-1, 27-1, 28-1). The Hexapodidae is derived as the sister to the Chasmocarcininae and Trogloplacinae and is united by six characters: an anteriorly tapered buccal frame (15-1), a relatively narrow male abdomen (23-0), short propodi of pereiopods 2-4 (52-0), possession of dactyli of pereiopods 2-4 with corneous tip (54-0), reduction of pereiopod 5 (58-1), and a short gonopod 2 (67-1), of which one is unique (581). The Hexapodidae + Chasmocarcininae + Trogloplacinae clade, with Bremer support of 4, is well supported by five synapomorphies: the absence of anterolateral spines (8-1), anterolateral and posterolateral margins not differentiated (9-1), absence of a 
carapace posterior carina (11-1), absence of endostomial ridges (16-1), and a narrow male abdominal somite 3 (24-1). A sister-group relationship of chasmocarcinines and trogloplacines is also well supported by three synapomorphies: the ischium of maxilliped 3 about equal to the merus (17-1), the presence of a supplementary plate on male thoracic sternite 8 (43-1), and male thoracic sternite 8 visible ventrally (45-1). The Carinocarcinoidinae + Hexapodidae + Chasmocarcininae + Trogloplacinae and Hexapodidae + Chasmocarcininae + Trogloplacinae clades each have high decay values and are well supported by unambiguous synapomorphies.

The Euryplacinae and Goneplacinae, basal within Clade F, lack the synapomorphies of the clade Carinocarcinoidinae + Hexapodidae + Chasmocarcininae + Trogloplacinae. Therefore, the Hexapodidae is not reduced to subfamily status within the Goneplacidae, but instead, the five recognized goneplacid subfamilies (Euryplacinae, Goneplacinae, Carinocarcinoidinae, Chasmocarcininae, Trogloplacinae) are elevated to full family status. Karasawa and Kato (2003a) had previously synonymised the Carcinoplacinae with the Goneplacinae, because in their phylogenetic analysis, the Carcinoplacinae cannot be clearly separated from the Goneplacinae.

Von Sternberg and Cumberlidge (2001) excluded the Goneplacidae from the Xanthoidea because the Goneplacidae was derived as the sister to the Portunoidea based upon their cladistic analysis, but they did not assign the family to any superfamily. Schweitzer (2005a) suggested that the Goneplacidae might warrant its own superfamily. The present analysis strongly supports the monophyly of the Euryplacidae, Goneplacidae, Carinocarcinoididae, Hexapodidae, Chasmocarcinidae, and Trogloplacidae by five synapomorphies; thus, these six families are placed within the superfamily Goneplacoidea.

The clade Portunoidea, with Bremer support of 2 , is a monophyletic group defined by four synapomorphies: immovable male abdominal somites 3-5 (27-1, 28-1), a spatulate dactylus of pereiopod 5 (55-1), a strongly curved gonopod 1 (61-2), and an inflated, strongly hooked base of gonopod 1 (62-1). Karasawa and Kato (2003a) erected a new subfamily Mathildellinae within the Goneplacidae and suggested that the subfamily formed the most basal clade within the family. However, in the current analysis, the Mathildellinae is the basal-most lineage within the Portunoidea clade and lacks synapomorphies of the Goneplacoidea. Therefore, the Mathildellinae should be given full family status, and the Mathildellidae is here placed within the Portunoidea. The Mathildellidae is derived as the sister to the Geryonidae and Portunidae.

A sister-group relationship of the Geryonidae and Portunidae, with Bremer support of 2, is well supported by six synapomorphies: the basal article of the antenna reaching the front (13-0), a shallow sternal groove 3/4 (30-1), a male sterno-abdominal cavity reaching the anterior thoracic sternite 4 (42-1), chelipeds lacking dark-colored fingers (48-1), the occlusal surface of the dactylus of the major cheliped with a molar tooth (49-1), and dactyli of pereiopods 2-4 without corneous tip (54-1).

The clade Portunidae is defined by three synapomorphies: male thoracic sternite 8 visible ventrally (44-1), a well developed posterolateral prolongation of episternite 7 (46-1), and the presence of a penial groove of male thoracic sternite (47-1). The presence of a penial groove of male thoracic sternite 8 (Rodriquez, 1992) is a unique synapomorphy. $\mathrm{Ng}$ (2000) erected a new monotypic genus, Raymanninus, for Benthochascon schmitti Rathbun, 1931, and noted that there is a close relationship between Raymanninus and the geryonid genera based upon characters of the carapace, sternum, abdomen, and gonopods. Raymanninus (Portunidae incertae sedis; Ng, 2000) is the earliest-derived taxon within the portunid clade. The analysis suggests that both the Carcininae and Polybiinae are polyphyletic, as Von Sternberg and Cumberlidge (2001) and Schubart and Reuschel (2005) have already indicated; therefore, the systematics of both of these subfamilies needs to be reevaluated.

A family of hydrothermal vent crabs, Bythograeidae Williams, 1980, was originally placed within its own superfamily Bythograeoidea, and suggested to be closely related to the Xanthidae sensu lato, Goneplacidae, and Portunidae (Williams, 1980). Guinot (1988) and Guinot et al. (2002) suggested that the Bythograeidae had close affinities with the marine Eriphiidae, Oziidae, 'Carcinoplacidae', and

Fig. 3. The familial arrangement of the genera known from the fossil record previously assigned to the Xanthoidea sensu lato, based upon our classification, and their stratigraphic distribution. 


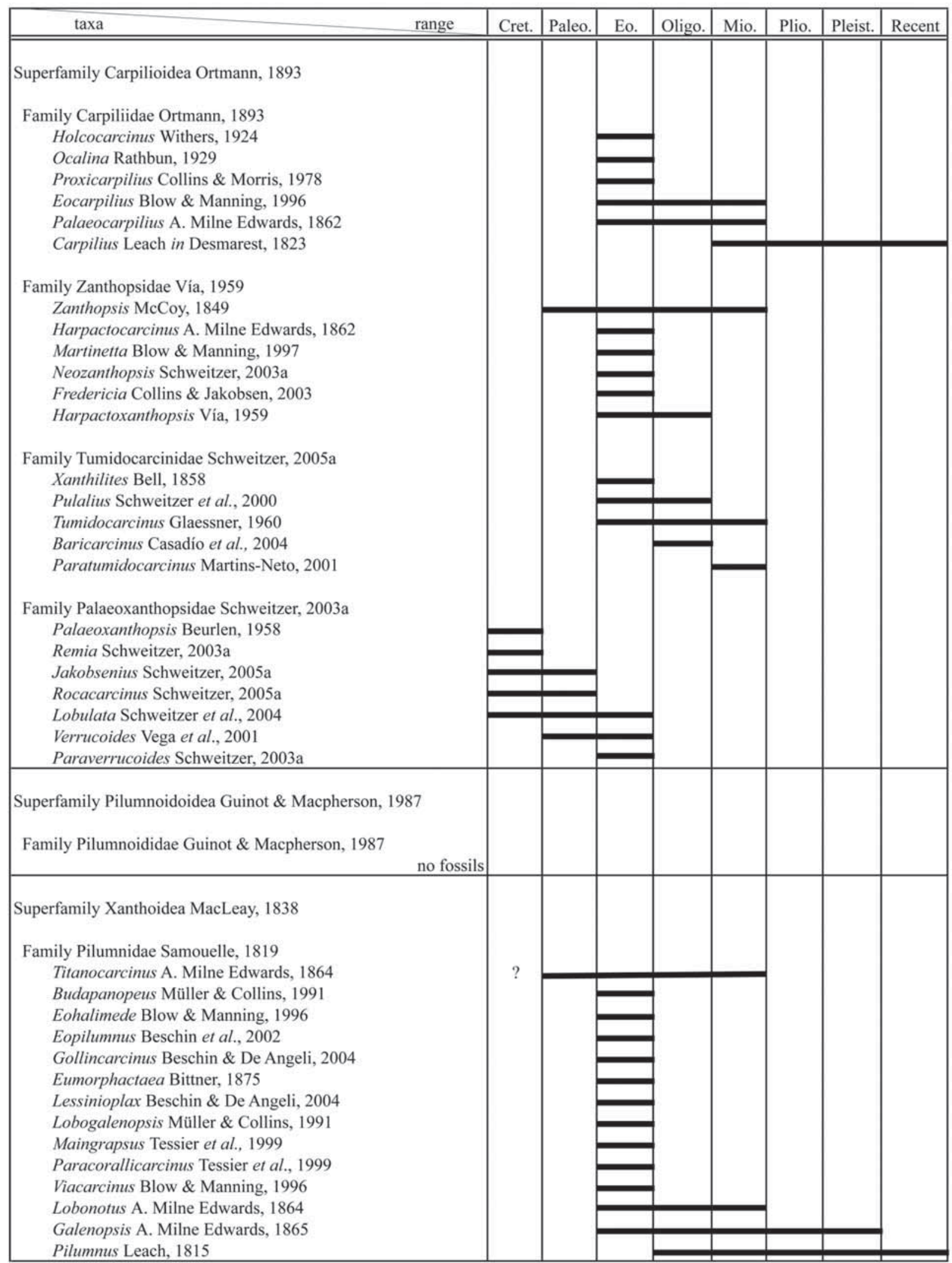




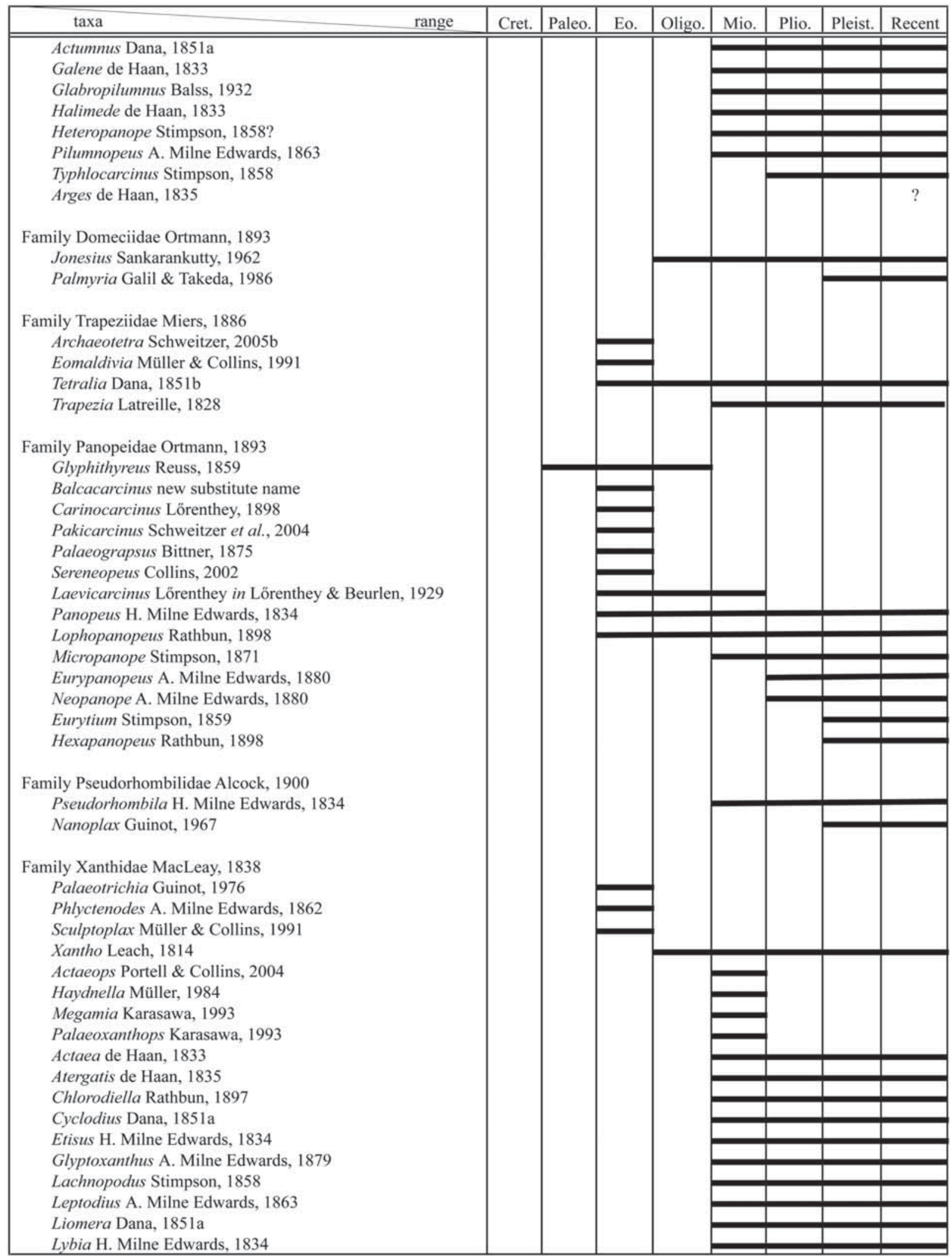




\begin{tabular}{|c|c|c|c|c|c|c|c|c|c|}
\hline taxa & range & Cret. & Paleo. & Eo. & Oligo. & Mio. & Plio. & Pleist. & Recent \\
\hline Medaeops Guinot, 1967 & & & & & & & & & \\
\hline $\begin{array}{l}\text { Medaeus Dana, 1851a } \\
\text { Monodaeus Guinot, } 1967\end{array}$ & & & & & & & & & \\
\hline Neoliomera Odhner, 1925 & & & & & & & & & \\
\hline Paraxanthias Odhner, 1925 & & & & & & & & & \\
\hline Pilodius Dana, 1851a & & & & & & & & & \\
\hline Xanthias Rathbun, 1897 & & & & & & & & & \\
\hline Xanthodius Stimpson, 1859 & & & & & & & & & \\
\hline Zosimus Leach in Desmarest, 1823 & & & & & & & & & \\
\hline Cycloxanthops Rathbun, 1897 & & & & & & & & & \\
\hline Demania Laurie, 1906 & & & & & & & & & \\
\hline Heteractaea Lockington, 1877 & & & & & & & & & \\
\hline Liagore de Haan, 1833 & & & & & & & & & \\
\hline Lipaesthesius Rathbun, 1898 & & & & & & & & & \\
\hline Metopoxantho de Man, 1904 & & & & & & & & & \\
\hline Banareia A. Milne Edwards, 1869 & & & & & & & & & \\
\hline Cymo de Haan, 1833 & & & & & & & & & \\
\hline Forestia Guinot, 1976 & & & & & & & & & \\
\hline Hypocolpus Rathbun, 1897 & & & & & & & & & \\
\hline $\begin{array}{l}\text { Macromedaeus Ward, } 1942 \\
\text { Paraxanthodes Guinot, } 1968\end{array}$ & & & & & & & & & \\
\hline Zalasius Rathbun, 1897 & & & & & & & & & \\
\hline Xanthoidea incertae sedis & & & & & & & & & \\
\hline Cretachlorodius Fraaye, 1996 & & & & & & & & & \\
\hline Creticarcinus Withers, 1922 & & & & & & & & & \\
\hline Megaxantho Vega et al., 2001 & & & & & & & & & \\
\hline Thelecarcinus Böhm, 1891? & & & & & & & & & \\
\hline Carpiliopsis Fischer-Benzon, 1866 & & & & & & & & & \\
\hline Cyclocorystes Bell, 1858 & & & & & & & & & \\
\hline Actaeopsis Carter, 1898 & & & & & & & & & \\
\hline Caprocancer Müller \& Collins, 1991 & & & & & & & & & \\
\hline Colpocaris von Meyer, 1863 & & & & & & & & & \\
\hline Eoplax Müller \& Collins, 1991 & & & & & & & & & \\
\hline Gemmacarcinus Müller \& Collins, 1991 & & & & & & & & & \\
\hline Pilumnomimus Müller \& Collins, 1991 & & & & & & & & & \\
\hline Martinocarcinus Böhm, 1922 & & & & & & & & & \\
\hline Paraxanthosia Müller \& Collins, 1991 & & & & & & & & & \\
\hline Prochlorodius Müller \& Collins, 1991 & & & & & & & & & \\
\hline Santeella Blow \& Manning, 1996 & & & & & & & & & \\
\hline Syphax A. Milne Edwards, 1863 & & & & & & & & & \\
\hline $\begin{array}{l}\text { Thelphusograpsus Lorenthey, } 1902 \\
\text { Pregeryona Hu \& Tao, } 1996\end{array}$ & & & & & & & & & \\
\hline Styrioplax Glaessner, 1969 & & & & & & & & & \\
\hline Wanga $\mathrm{Hu} \& \mathrm{Tao}, 1996 ?$ & & & & & & & & & \\
\hline Eoxanthias Hu \& Tao, 1996 & & & & & & & & & \\
\hline Superfamily Eriphioidea MacLeay, 1838 & & & & & & & & & \\
\hline Family Platyxanthidae Guinot, 1977 & & & & & & & & & \\
\hline Pelaeus Eydoux \& Souleyet, 1842 & & & & & & & & & \\
\hline Platyxanthus A. Milne Edwards, 1863 & & & & & & & & & \\
\hline $\begin{array}{l}\text { Family Hypothalassiidae new family } \\
\text { new genus for Titanocarcinus aculeatus }\end{array}$ & & & & & & & & & \\
\hline
\end{tabular}




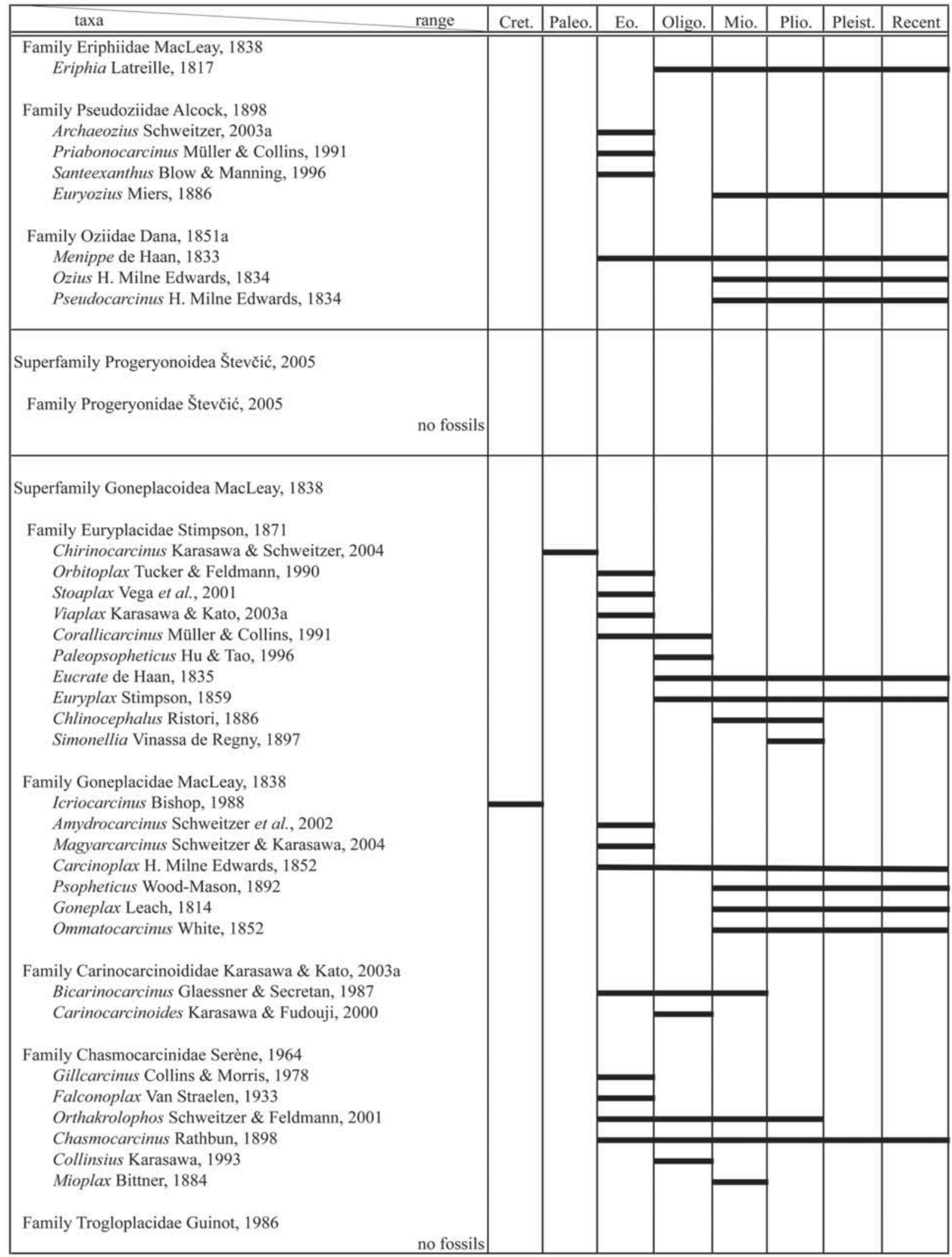




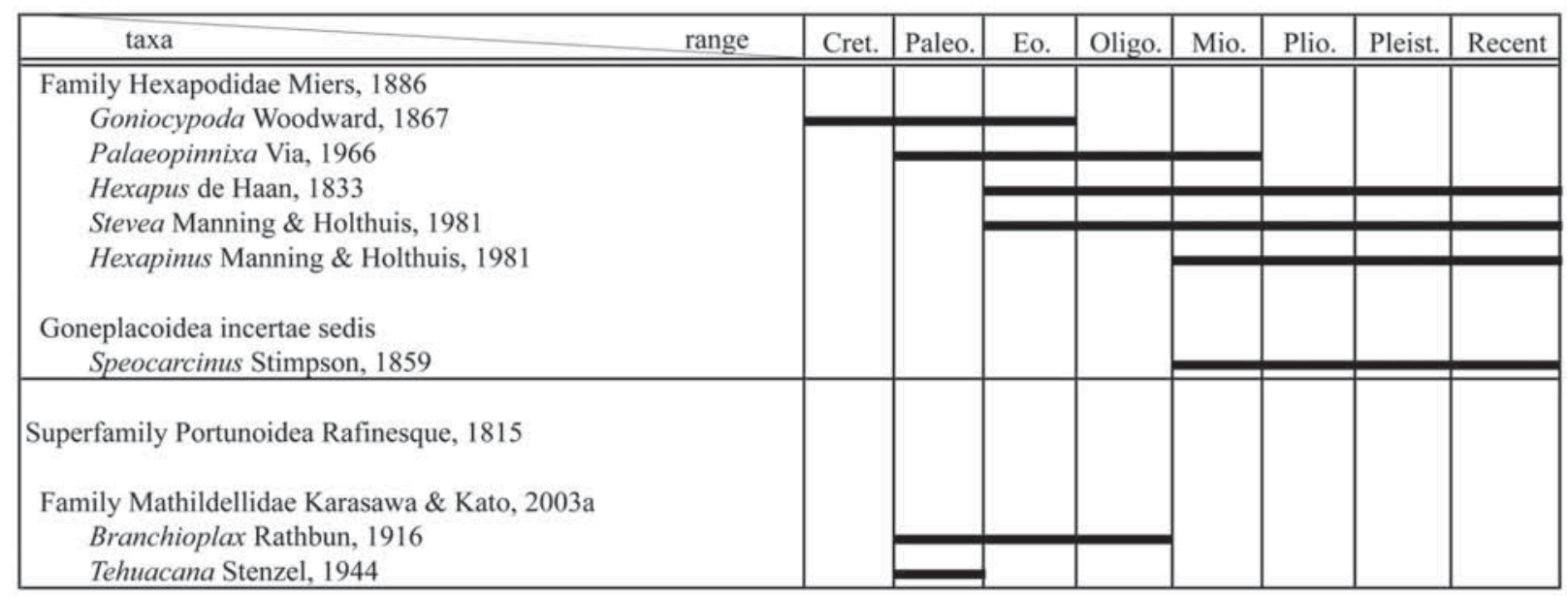

the freshwater Pseudothelphusidae Ortmann, 1893, based upon adult morphology. Tudge et al. (1998) proposed a close relationship between the Bythograeidae and the putative trapeziid genus Calocarcinus Calman, 1909, based upon spermatozoal ultrastructure. Von Sternberg et al. (1999) and Von Sternberg and Cumberlidge (2001) suggested a relationship between the Bythograeidae, the freshwater crab families, and the Thoracotremata. The systematic position of the Bythograeoidea and/or Bythograeidae is interesting but beyond the scope of our study.

\section{Systematic paleontology: superfamilies and families recognized herein}

General. Our diagnoses for each taxon include features of the carapace and other morphologic characters that are not necessarily synapomorphic for the superfamily but that do in fact characterize them. These features are essential to produce an overall diagnosis for the taxon at hand, whether it be a family or superfamily. As has been pointed out in earlier manuscripts (Schweitzer, 2003a, b), it is necessary to use a suite of characters to refer fossil, and often

Table 4. Superfamily and family arrangement of the Xanthoidea sensu lato proposed herein. $†$ indicates a group that is extinct and extant; †† indicates an extinct group.

\footnotetext{
Section Heterotremata Guinot, 1977

Superfamily Carpilioidea Ortmann, 1893 †

Family Carpiliidae Ortmann, $1893 \dagger$

Family Palaeoxanthopsidae Schweitzer, 2003 ††

Family Tumidocarcinidae Schweitzer, 2005 ††

Family Zanthopsidae Vía, 1959 ††

Superfamily Pilumnoidoidea Guinot \& Macpherson, 1987

Family Pilumnoididae Guinot \& Macpherson, 1987

Superfamily Xanthoidea MacLeay, 1838 † sensu stricto

Family Domeciidae Ortmann, 1893 †

Family Panopeidae Ortmann, $1893 \dagger$

Family Pilumnidae Samouelle, 1819 †

Family Pseudorhombilidae Alcock, $1900 \dagger$

Family Trapeziidae Miers, 1886 †

Family Xanthidae MacLeay, 1838 † sensu stricto

Superfamily Eriphioidea MacLeay, 1838 †

Family Eriphiidae MacLeay, $1838 \dagger$
}

Family Hypothalassiidae new family

Family Oziidae Dana, 1851 †

Family Platyxanthidae Guinot, $1977 \dagger$

Family Pseudoziidae Alcock, 1898 †

Superfamily Progeryonoidea Števčić, 2005

Family Progeryonidae Števčić, 2005

Superfamily Goneplacoidea MacLeay, 1838 †

Family Carinocarcinoididae Karasawa \& Kato, 2003 ††

Family Chasmocarcinidae Serène, $1964 \dagger$

Family Euryplacidae Stimpson, 1871 †

Family Goneplacidae MacLeay, 1838 †

Family Hexapodidae Miers, $1886 \dagger$

Family Trogloplacidae Guinot, 1986

Superfamily Portunoidea Rafinesque, $1815 \dagger$

Family Carcineretidae Beurlen, 1930 ††

Family Geryonidae Colosi, 1923 †

Family Mathildellidae Karasawa \& Kato, 2003 †

Family Portunidae Rafinesque, $1815 \dagger$ 
extant, specimens to taxa within the Xanthoidea sensu lato, because of the high degree of homoplasy and convergent evolution within the group. This is especially true for fossil specimens in which gonopods, pleopods, antennae, and other morphological parts with a poor fossilization potential are rarely accessible and in which dorsal carapace characters, termed proxy characters (Schweitzer and Feldmann, 2000a) because they track the diagnostic soft part anatomy typically used by biologists, are especially necessary. They are usually all that is preserved.

Genera discussed below that have been reassigned at the family level are compiled in Table 5.

Notations used. Taxa listed in 'Included families' headings are extant only unless marked otherwise. Genera listed in 'Included fossil genera' headings are extinct unless otherwise noted. Characters synapomorphic and/or diagnostic for the family or superfamily are italicized in the diagnoses; often characters must be used in combination with one another, especially to diagnose fossil specimens.

Infraorder Brachyura Latreille, 1802

Section Heterotremata Guinot, 1977

Superfamily Carpilioidea Ortmann, 1893

Included families. Carpiliidae Ortmann, 1893 (extinct and extant); Palaeoxanthopsidae Schweitzer, 2003a (extinct); Tumidocarcinidae Schweitzer, 2005a (extinct); Zanthopsidae Vía, 1959 (extinct).

Diagnosis. Carapace wider than long, maximum carapace length 70-80 percent maximum carapace width, ovate or hexagonal in shape, position of maximum width between half and three-quarters the distance posteriorly on carapace; dorsal surface generally not densely ornamented but may have large spherical swellings, regions range from well defined to very poorly defined; anterolateral margins entire or with spines or lobes; front with a medial sulcus, bi- or quadrilobed, frontal width between one-quarter to two-thirds maximum carapace width; antenna situated outside the supraorbital angle; orbits entire or rarely with clearly defined upper orbital fissures, fronto-orbital width between half and two-thirds maximum carapace width; medial sulcus on male thoracic sternite 4, male sternum may exhibit distinctive Y-shaped groove pattern (Palaeoxanthopsidae, Tumidocarcinidae, Zanthopsidae; see Schweitzer, 2005a, for illustrations), sternal sutures 4/5 and 5/6 of both sexes complete or incomplete and sometimes parallel, sutures 6/7 and 7/8 complete; male abdomen entirely occupying space between coxae of fifth pereiopods; sternite 8 not visible in ventral view; male abdominal somites free or 3-5 fused with suture between somites $4 / 5$ sometimes visible; chelipeds at least weakly heterochelous, sometimes markedly so in males; occlusal surface of dactylus of major chela with a basal molar tooth; absence of corneous tips of pereiopods 2-4; cylindrical propodi of pereiopods 2-5.

\section{Occurrence. Cretaceous - Recent.}

Discussion. Work on the families referred to the Carpilioidea has largely been conducted in recent years (Vega, Cosma et al., 2001; Schweitzer, 2003a, b; Schweitzer et al., 2004; Schweitzer, 2005a; Schweit-

Table 5. Genera that have been moved herein to a different family.

\begin{tabular}{lll}
\hline Taxon & Previous Family Designation & Current Family Designation \\
\hline Budapanopeus Müller and Collins, 1991 & Xanthidae sensu lato & Pilumnidae \\
Caloxanthus A. Milne-Edwards, 1864 & Xanthidae sensu lato & Etyidae \\
Eumorphactaea Bittner, 1875 & Xanthidae sensu lato & Pilumnidae \\
Fredericia Collins \& Jakobsen, 2003 & Xanthidae sensu lato & Zanthopsidae \\
Gemmacarcinus Müller and Collins, 1991 & Leucosiidae Samouelle, 1819 & Xanthoidea incertae sedis \\
Gollincarcinus Beschin \& De Angeli, 2004 & Goneplacidae & Pilumnidae \\
Hypothalassia Gistel, 1848 & Eriphiidae sensu lato & Hypothalassiidae new family \\
Lessinioplax Beschin \& De Angeli, 2004 & Goneplacidae & Pilumnidae \\
Lobogalenopsis Müller \& Collins, 1991 & Xanthidae sensu lato & Pilumnidae \\
Progeryon Bouvier, 1922 & Xanthidae sensu lato; Goneplacidae sensu lato & Progeryonidae new family \\
Viacarcinus Blow \& Manning, 1996 & Eumedonidae & Pilumnidae \\
Xandaros Bishop, 1988 & Xanthidae sensu lato & Dromiidae
\end{tabular}


zer et al., 2005). The four families referred here to the superfamily each exhibit an excellent fossil record; three are extinct. In spite of some being known only from fossils, a surprisingly detailed diagnosis can be made for these taxa, including features of the sternum and male abdomen which traditionally have been considered to be important for brachyuran classification.

The phylogenetic analysis presented here shows the superfamily to be well supported by six synapomorphies. Further, the excellent fossil record for each family, extending well back into the Paleogene or even the Cretaceous, suggests that this is indeed a closely related lineage. The earliest occurrences of all but one of these families (Carpiliidae [Eocene], Palaeoxanthopsidae [Cretaceous], Zanthopsidae [Paleocene]) is Tethyan, suggesting a possible single area of origin for the superfamily and subsequent radiation to other areas. The families with known paleoecological preferences inhabited somewhat different habitats. The Carpiliidae, in the Eocene and Miocene, as now, are known from tropical warm climates, in at least photic zone depths (Müller, 1984; Feldmann et al., 1998). The Zanthopsidae, on the other hand, preferred off-shore, clear, shelf environments below fair-weather wave base (Schweitzer et al., 2005). The Eocene to Miocene Tumidocarcinidae are typically found in deeper, quiet water, siliciclastic habitats (Glaessner, 1960; Feldmann, 1998; Casadío et al., 2004). Thus, there may have been early differentiation within the superfamily for different environments.

\section{Family Carpiliidae Ortmann, 1893}

Included fossil genera. Carpilius Leach in Desmarest, 1823 (also extant); Eocarpilius Blow and Manning, 1996; Holcocarcinus Withers, 1924; Ocalina Rathbun, 1929; Palaeocarpilius A. Milne-Edwards, 1862; Proxicarpilius Collins and Morris, 1978.

\section{Occurrence. Eocene - Recent.}

Diagnosis. Carapace wider than long, length about 70-80 percent maximum carapace width, widest about two-thirds to three-quarters the distance posteriorly on carapace; may be ornamented with large, flat swellings; regions moderately to poorly defined; grooves not developed except branchiocardiac groove in some cases. Front usually with bilobed medial projection and blunt inner orbital spines, thus appearing quadrilobed, but may be produced into downturned, blunt triangle; notch between frontal margin and supraorbital angle indistinct, frontal width averaging 36 percent maximum carapace width. Orbits circular, entire, rimmed or beaded, directed forward, fronto-orbital width about half to two-thirds maximum carapace width. Anterolateral margin may be entire or with blunt lobes or spines; last spine may be extended onto dorsal carapace as short, low ridge; anterolateral margin long, much longer than posterolateral margin, terminating twothirds to three-quarters the distance posteriorly, concave, tightly curved posteriorly, often very convex posteriorly. Posterolateral margin straight or weakly convex, short, at a very low angle to posterior margin, around 25-30 degrees; posterior margin nearly straight, narrow, averaging about 30 percent maximum carapace width.

Carapace regions may be weakly inflated or not defined. Branchiocardiac groove often defining lateral margins of urogastric region. Buccal frame usually tapering anteriorly. Thoracic sternum narrow, rectangular, with subparallel margins; sternite 3 without medial groove; articulation condyle of pereiopods on sternum; sutures 4/5-7/8 complete, parallel; sternite 8 not visible in ventral view. Male abdominal somites 3-5 fused, abdomen filling entire space between coxae of fifth pereiopods. Chelae large, subequal or heterochelous; outer, upper and lower surfaces generally smooth, upper surface may have blunt nodes; chelipeds much larger than other walking legs; merus fused to basis-ischium; merus and coxa articulating directly. Pereiopods 2-5 narrow, smooth, tubular. Male gonopod 1 weakly curved, stout, with simple apex. Male gonopod 2 long with long, filamentous flagellum (after Schweitzer, 2003a: 1110).

Family Palaeoxanthopsidae Schweitzer, 2003a

Included fossil genera. Jakobsenius Schweitzer, 2005a; Lobulata Schweitzer, Feldmann, and Gingerich, 2004; Palaeoxanthopsis Beurlen, 1958; Paraverrucoides Schweitzer, 2003a; Remia Schweitzer, 2003a; Rocacarcinus Schweitzer, 2005a; Verrucoides Vega et al., 2001.

Occurrence. Cretaceous - Eocene. 
Diagnosis. Carapace wider than long, maximum carapace length about 75 percent maximum carapace width, position of maximum width about half to twothirds the distance posteriorly; regions defined by grooves; moderately or deeply incised, $V$-shaped groove separating gastric regions from hepatic and branchial regions; regions may be moderately or weakly inflated, often with large, spherical swellings. Frontal width about 20 percent maximum carapace width, quadrilobed, medial two lobes may project well beyond orbits. Orbits with two fissures or sutures, rectangular, sometimes rimmed, outer-orbital angle a projected spine, fronto-orbital width about half maximum carapace width. Anterolateral margin with a straight segment followed by three to five spines not including outer-orbital spine; spines wellseparated by notches or fissures; last spine longest, directed laterally or posterolaterally. Posterior margin narrow, concave, about one-quarter maximum carapace width. Branchial regions often with linear, transverse swellings.

Male sternum with no evidence of suture between sternites 2 and 3; may exhibit distinctive Y-shaped groove pattern on sternites 3 and 4; sternal suture $3 / 4$ oriented at steep angle; sternite 4 with large episternal projection; sternite 4 with very clear, longitudinal grooves near lateral margins, which appear to be episternal projections from sternite 3 fused with and prominent on sternite 4; male abdominal somites free.

Female sternum with deep suture between sternite 2/3; groove from sterno-abdominal cavity extending anteriorly onto sternite 4; abdomen reaching level of base of coxae of pereiopods 1 .

Discussion. Schweitzer (2003a) erected the Palaeoxanthopsidae and referred four genera to it. Subsequently, more genera were named and added, resulting in a slight broadening of the diagnosis and addition of details of the sternum of males and females (Schweitzer et al., 2004; Schweitzer, 2005a). The above diagnosis embraces all of the referred genera to date.

Family Tumidocarcinidae Schweitzer, 2005a

Included genera (all fossil). Baricarcinus Casadío et al., 2004; Paratumidocarcinus Martins-Neto, 2001; Pulalius Schweitzer et al., 2000; Tumidocarcinus
Glaessner, 1960; Xanthilites Bell, 1858.

Occurrence. Eocene - Miocene.

Diagnosis. Carapace wider than long, L/W about 0.80 , widest at position of last or penultimate anterolateral spine, about half the distance posteriorly on carapace; carapace markedly vaulted longitudinally, especially in anterior third; front four-lobed including inner-orbital spines, frontal width about onequarter maximum carapace width; fronto-orbital width a little less than half maximum carapace width; orbits rimmed, sometimes with very faint, completely fused fissure, circular, directed forward; antenna situated outside supraorbital angle; carapace regions well defined to poorly defined; anterolateral margins with three or four small, blunt spines excluding outer orbital spine or entire and granular; epibranchial regions usually arcuate.

Male sternites 1 and 2 fused with no evidence of suture; very clear, deep, continuous suture between sternites 2 and 3; sternites 3 and 4 with notch in lateral margins where suture intersects it, suture becoming increasingly shallow, becoming a shallow groove at midlength, completely interrupted axially; left and right sternal sutures between sternites 3 and 4 merge with deep groove extending anteriorly from sternoabdominal cavity, forming prominent, Y-shaped groove pattern; suture between sternites 3 and 4 oriented at high angle; sternite 4 with very clear, longitudinal grooves near lateral margins, which appear to be episternal projections from sternite 3 fused with and prominent on sternite 4; sternal sutures not parallel; sternite 8 not visible in ventral view.

Male abdomen barely reaching or not quite reaching posterior margin of coxae of first pereiopods; all male abdominal somites free; male abdomen completely occupying space between coxae of fifth pereiopods.

Chelae subequal to very unequal; mani stout; fingers with black tips; coxae of first pereiopods articulating with basis-ischium, basis-ischium not fused to merus; other pereiopods slender (after Schweitzer 2005a: 282).

Family Zanthopsidae Vía, 1959

Included genera (all fossil). Fredericia Collins and Jakobsen, 2003; Harpactocarcinus A. Milne-Ed- 
wards, 1862; Harpactoxanthopsis Vía, 1959; Martinetta Blow and Manning, 1997; Neozanthopsis Schweitzer, 2003a; Zanthopsis McCoy, 1849.

Occurrence. Paleocene - Miocene.

Emended Diagnosis. Carapace wider than long, maximum carapace length about 80 percent maximum carapace width, widest about one-half to twothirds the distance posteriorly on carapace; ovate or circular in shape; may be ornamented with large swellings, sometimes arranged on ridges; regions poorly or moderately defined; branchiocardiac groove well-developed; front with four blunt spines including inner orbital spines, frontal width about one-quarter maximum carapace width; orbits circular or rectangular, entire, rimmed, fronto-orbital width about half maximum carapace width; anterolateral margin convex, entire, with three to five blunt spines, or with numerous small spines; last anterolateral spine may extend onto carapace as long, low ridge; anterolateral margin often tightly arched posteriorly; anterolateral margin about as long or slightly longer than posterolateral margin; posterolateral margin sinuous or weakly concave; posterior margin nearly straight, 30-40 percent maximum carapace width.

Sternum narrow, ovate, broadest anteriorly at position of fourth sternite, narrowing posteriorly; sternal suture 4/5 incomplete; sutures 5/6-7/8 complete; sutures 4/5 and 5/6 not parallel; sternite 4 in males and females with swelling just anterior to episternal projection of sternite 4; sternite 4 with clear longitudinal grooves near lateral margins that appear to be episternal projections of sternite 3 fused with sternite 4; sternite 8 not visible in ventral view. Male abdomen with somites 3-5 fused, suture between 4/5 visible; somite 3 with lateral extensions often ornamented with spherical swellings; telson longer than somite 6; male abdomen reaching base or middle of coxa of pereiopod 1; male abdomen covering entire space between coxae of pereiopods 5 . Chelae large, subequal or weakly heterochelous, outer surface smooth or with large swellings, upper and lower margins with numerous small spines; chelipeds much longer than walking legs; ischium of major cheliped articulating with coxa, merus not fused completely to ischium.

Discussion. The emended diagnosis is based upon material examined in the Museu Geològic del
Seminari de Barcelona (Harpactocarcinus punctulatus [Desmarest, 1823], MGSB 10815, 6404, 9935) during the summer of 2004 (CS) and Harpactoxanthopsis lutugini (Likharev, 1917) and Zanthopsis bispinosa Bell, 1858, deposited in the Mizunami Fossil Museum (HK). These specimens have extremely well preserved sterna and abdomina; thus, new observations were made and are herein recorded.

Fredericia Collins and Jakobsen, 2003, is added to the family based upon the carapace shape; projected front with four spines; entire orbits; frontoorbital width about half the maximum carapace width; weak Y-shaped groove on sternum; sternite 4 with clear longitudinal grooves near lateral margins which appear to be episternal projections of sternite 3 fused with sternite 4; sternite 8 not visible in ventral view; fused male abdominal somites 3-5; and male somite 3 with lateral projections. All of these characters are diagnostic for the family and make placement of Fredericia within the Zanthopsidae quite certain.

Superfamily Pilumnoidoidea Guinot and Macpherson, 1987

Included family. Pilumnoididae Guinot and Macpherson, 1987

Occurrence. Recent.

Diagnosis. As for Pilumnoididae.

Family Pilumnoididae Guinot and Macpherson, 1987

Included genus. Pilumnoides Lucas in H. Milne Edwards and Lucas, 1843.

\section{Occurrence. Recent.}

Diagnosis. Carapace ovate or subhexagonal, wider than long, maximum carapace length about 80 percent maximum carapace width, widest about 60 percent the distance posteriorly; regions usually well-defined, usually granular but may be smooth (Pilumnoides inglei Guinot and Macpherson, 1987); front with axial notch, may have weak projection just to orbit, frontal width about one-third maximum 
carapace width; orbits may have two closed fissures, fronto-orbital width about half to two-thirds maximum carapace width; anterolateral margins with four or five spines or lobes excluding outer-orbital spine or with numerous granules or spinelets. Endostomial crests complete. Sternum narrow, long, sutures 4/5, 5/6, 6/7 and 7/8 uninterrupted and subparallel, sternite 8 not visible in ventral view. All male abdominal somites free, male abdomen completely covering space between coxae of fifth pereiopods. Male gonopod 1 long, straight, slightly incurved, with a terminal opening, ornamented with tubercles, rarely with setae; male gonopod 2 medium in length, straight, with a well-developed peduncle, flagellum short. Chelipeds weakly heterochelous, often with rows of tubercles on outer surface of manus; chelipeds much more robust than pereiopods 2-5; merus fused to basis-ischium. (After Guinot and Macpherson, 1987).

Discussion. Guinot and Macpherson (1987) created the subfamily Pilumnoidinae to embrace the unusual genus Pilumnoides, which they considered to be a plesiomorphic genus within the Xanthoidea sensu Guinot, 1977. They considered it to be an evolutionary grade similar to the Carpiliidae (Guinot and Macpherson, 1987: 218), which is interestingly where it appears in our analysis. Guinot and Macpherson (1987) compared their monotypic subfamily to several other families and subfamilies within the Xanthoidea sensu Guinot, 1977, but the unusual suite of characters could not be accommodated by any of them. Other authors have maintained the Pilumnoidinae within the Goneplacidae sensu lato (Davie, 2002). However, Karasawa and Kato (2003b) excluded the Pilumnoidinae within the Goneplacidae based upon cladistic analysis and showed that the subfamily was the sister to the Carpiliidae. All Goneplacoidea as herein defined have all sternal sutures interrupted and indistinct and relatively unornamented regions, which cannot accommodate the Pilumnoidinae. We herein raise the subfamily to family status and create a new superfamily for it.

Superfamily Xanthoidea MacLeay, 1838 sensu stricto

Included families. Pilumnidae Samouelle, 1819; Domeciidae Ortmann, 1893; Trapeziidae Miers, 1886;
Panopeidae Ortmann, 1893; Pseudorhombilidae, Alcock, 1900; Xanthidae MacLeay, 1838 sensu stricto.

\section{Occurrence. Cretaceous - Recent.}

Diagnosis. Carapace hexagonal, ovate, rectangular, or circular, usually wider than long, maximum length from 66 - 100 percent maximum carapace width, usually between 75 - 85 percent, usually widest about 40 - 50 percent the distance posteriorly but two-thirds to three-quarters the distance in most Xanthidae; carapace regions poorly defined to very well defined; front usually bilobed but may be entire or multilobed, frontal width about one-quarter to half maximum carapace width; orbits may have two fissures or notches, fronto-orbital width ranging from half to 90+ percent maximum carapace width; anterolateral margin entire or with between two and six spines or lobes excluding outer-orbital spines, anterolateral and posterolateral margins usually distinct from one another, posterolateral margin straight or concave.

Male gonopod 1 slender. Male gonopod 2 short. Sternum narrow, sternal sutures 4/5 and 5/6 interrupted, sternal sutures 6/7 and 7/8 complete. Male abdominal somites free or somites 3-5 fused, sutures may be visible. Chelipeds subequal or heterochelous, fingers often with black tips.

\section{Family Domeciidae Ortmann, 1893}

Included fossil genera. Jonesius Sankarankutty, 1962 (also extant); Palmyria Galil and Takeda, 1986 (also extant).

\section{Occurrence. Oligocene - Recent.}

Diagnosis. Carapace hexagonal or ovate, wider than long, maximum carapace length averaging about 80 percent maximum carapace width, position of maximum width about 40 percent the distance posteriorly on carapace; regions poorly defined; front bilobed, sometimes granular or spinose, about half maximum carapace width; orbits shallow, semi-circular, directed forward, fronto-orbital width averaging about 80 percent maximum carapace width; anterolateral margin extending obliquely and distally from outer-orbital corner, often spinose. Basal 
article of antenna not reaching front. Merus of third maxilliped short, much wider than long; "second maxilliped with endopod having propodus and dactylus fused into a very large endite" (Davie, 2002: 152). Male gonopod 1 stout, sinuous, with blunt tip; male gonopod 2 about half the length of gonopod one, thick proximally. Male abdomen with somites 3-5 fused, sutures may be visible, third somite in some taxa much wider than other somites. Chelipeds equal or unequal, usually strongly granular or spinose, merus short; pereiopods 2-5 "with dactylopropodal articulation formed by rounded prolongation of propodal lateral margin sliding against and beneath a projecting button situated proximally on lateral margin of dactylus" (Davie, 2002: 152). (After Davie, 2002; Castro et al., 2004; Schweitzer, 2005b: 625).

Family Panopeidae Ortmann, 1893

Included fossil genera. Balcacarcinus new substitute name for Bittneria Schweitzer and Karasawa, 2004 (see below); Carinocarcinus Lórenthey, 1898; Eurypanopeus A. Milne-Edwards, 1880 (also extant); Eurytium Stimpson, 1859 (also extant); Glyphithyreus Reuss, 1859; Hexapanopeus Rathbun, 1898 (also extant); Laevicarcinus Lórenthey in Lórenthey and Beurlen, 1929; Lophopanopeus Rathbun, 1898 (also extant); Micropanope Stimpson, 1871 (also extant); Neopanope A. Milne-Edwards, 1880 (also extant); Pakicarcinus Schweitzer et al., 2004; Palaeograpsus Bittner, 1875; Panopeus H. Milne Edwards, 1834 (also extant); Sereneopeus Collins, 2002.

Occurrence. Paleocene - Recent.

Diagnosis. Carapace hexagonal, transversely ovate, or sometimes circular, wider than long, $L / W$ ranging from 0.70-0.95, point of maximum width about 40-50 percent the distance posteriorly on carapace; carapace flattened, regions moderately well-marked to weakly defined; front bilobed, ranging from 30 to 43 percent maximum carapace width; orbits with two fissures or notches, fronto-orbital width about 60-80 percent maximum carapace width; anterolateral margin entire or with 2 - 4 spines excluding outer-orbital spine; anterolateral margins usually distinct from posterolateral margins. Sternum narrow or wide, triangular in shape, sometimes comparatively large portion of sternite 8 visible in ventral view; male abdominal somites 1, 2, and 3 usually covering entire space between fifth pereiopods; male abdominal somites 3-5 fused, sutures may be evident. Male genital openings coxal or coxo-sternal but penis often lies in a more or less elongate sternal (coxo-sternal) position. Male gonopod 1 slender, curved or straight, sometimes with spines or setae, with several, sometimes complex, apical extensions. Gonopod 2 short, less than 25 percent length of gonopod 1, curved. Chelipeds subequal or heterochelous; with pointed fingers or with spoon-shaped tips, tips may be black; pereiopods 2-5 long, without dactylo-propodal articulation. Diagnosis after Rathbun (1918), Davie (2002), and Schweitzer and Karasawa (2004).

\section{Genus Balcacarcinus new substitute name}

Bittneria Schweitzer and Karasawa, 2004: 80, fig. 1.6 (non Bittneria Broili, 1904, p. 168).

Type species. Palaeograpsus attenuatus Bittner, 1875 , by monotypy.

Description. See Schweitzer and Karasawa (2004).

Etymology. The genus name is derived from the AngloSaxon word balca, meaning ridge, and the Greek word karkinos, meaning crab and a common ending for brachyuran generic names, in reference to the numerous ridges on the dorsal carapace in this taxon.

Discussion. Schweitzer and Karasawa (2004) erected the genus Bittneria to accommodate Palaeograpsus attenuatus in their revision of Palaeograpsus. However, the name Bittneria is preoccupied by a genus of mollusc (Broili, 1904); thus, we herein provide the substitute name, Balcacarcinus, to replace Bittneria Schweitzer and Karasawa, 2004, as per Article 60.3 of the International Code of Zoological Nomenclature (1999).

Family Pilumnidae Samouelle, 1819

Included fossil genera. Actumnus Dana, 1851a (also extant); Arges De Haan, 1835; Budapanopeus Müller 
and Collins, 1991; Eohalimede Blow and Manning, 1996; Eopilumnus Beschin et al., 2002; Eumorphactaea Bittner, 1875; Galene De Haan, 1835 (also extant); Galenopsis A. Milne-Edwards, 1865; Glabropilumnus Balss, 1932 (also extant); Gollincarcinus Beschin and De Angeli, 2004; Halimede De Haan, 1833 (also extant); Lessinioplax Beschin and De Angeli, 2004; Lobogalenopsis Müller and Collins, 1991; Lobonotus A. Milne-Edwards, 1864; Maingrapsus Tessier et al., 1999; Paracorallicarcinus Tessier et al., 1999; Pilumnus Leach, 1815 (also extant); Pilumnopeus A. Milne-Edwards, 1863 (also extant); Titanocarcinus A. Milne-Edwards, 1864; Typhlocarcinus Stimpson, 1858 (also extant); Viacarcinus Blow and Manning, 1996. The presence of Heteropanope Stimpson, 1858 (also extant) in the fossil record must be evaluated by examination of type material of Heteropanope? wylliei Glaessner, 1933, to confirm its placement in the genus.

Occurrence. Cretaceous - Recent. The Cretaceous occurrence is based upon Titanocarcinus serratifrons A. Milne-Edwards, 1864, reported from southern Belgium in rocks of late Maastrichtian age (J. Jagt, personal commun.). Although we have been unable to locate the type of $T$. serratifrons, the species is well described and illustrated and appears at this time to be referrable to the Pilumnidae. Numerous Eocene occurrences of the family are known (A. Milne-Edwards, 1864, 1865; Müller and Collins, 1991; Blow and Manning, 1996; Beschin and De Angeli, 2004).

Diagnosis. Carapace hexagonal (Galeninae A. Milne-Edwards, 1862; Halimedinae Alcock, 1898; Pilumninae Samouelle, 1819), transversely rectangular (Rhizopinae Stimpson, 1858), ovate (Calmaniinae Števčić, 1991), or bizarrely projected (Eumedoninae Dana, 1853), wider than long, maximum carapace length usually about 70 - 80 percent maximum carapace width but may be much higher (90 + percent in Calmaniinae, Eumedoninae, and Halimedinae), position of maximum width variable among and within subfamilies; dorsal surface convex, often markedly so in anterior onethird; regions smooth or granular and setose, sometimes with transverse swellings (Rhizopinae); frontal margin entire, bilobate, with many lobes, or greatly anteriorly projected (Eumedoninae), front usually ranges from one-third to half maximum carapace width but may be much lower (about 20 percent in Galeninae, some Rhizopinae); orbits usually with two orbital notches or fissures, fronto-orbital width two-thirds to three-quarters (Calmaniinae, Eumedoninae, Halimedinae, Pilumninae) or 40 - 60 percent (Galeninae, Rhizopinae) maximum carapace width; anterolateral margins usually with spines, often 1 - 4 (Galeninae, Halimedinae, Pilumninae, some Rhizopinae), but can be entire or indistinctly lobate (Calmaniinae, Eumedoninae, some Rhizopinae); gastric regions often long; usually anterolateral and posterolateral margins distinct from one another. Endostome with crests defining efferent branchial channels at least moderately developed and continuing to anterior margin of buccal cavity (Davie, 2002: 392). Sternal sutures 4/5 and 5/6 interrupted medially; posterolateral prolongation of sternite 7 well marked; sternite 8 not visible ventrally. All male abdominal somites free, narrow, covering most of sternite 4, abdominal locking mechanism ('bouton-presson') present; male genital openings coxal or coxo-sternal. Male gonopod 1 slender or stout, sinuous, tip usually simple and recurved; gonopod 2 very short and sigmoid. Chelae subequal or heterochelous, fingers may have black tips; pereiopods short or moderately long. Subfamilies as defined by Davie (2002) and Poore (2004).

Discussion. The Pilumnidae as currently defined is a diverse group that is acknowledged to be in need of revision at the species, generic, and subfamily levels (Davie, 2002). Števčić (2005) separated the Pilumnidae into numerous subfamilies and tribes. Evaluation of these many subdivisions is beyond the scope of this paper. We follow primarily Davie (2002) in the definition of the family, and have previously discussed the problems attendant with such taxa as Galene and the Galeninae (Schweitzer, 2005a). Schweitzer (2005a) also discussed the fact that the subfamilies are so different from one another that at least in discussions of fossil taxa, it may be necessary to make comparisons to each included subfamily rather than the family as a whole. Davie (2002) and Poore (2004) each provided good subfamily diagnoses which need not be repeated here.

Beschin and De Angeli (2004) described Gollincarcinus and Lessinioplax, both from the Eocene 
of Italy. They placed those two genera within the Goneplacidae, and noted similarities with Magyarcarcinus Schweitzer and Karasawa, 2004, and Palaeograpsus Bittner, 1875, for the former, and Georgeoplax Türkay, 1983, for the latter. There are in fact similarities among the four genera, but those similarities appear to be superficial. We place Gollincarcinus and Lessinioplax within the Pilumnidae, because they are similar morphologically to Georgeoplax. The family placement of Georgeoplax itself has been the subject of much debate, which was recently summarized (Karasawa and Kato, 2003b), and the genus was placed within the Pilumnidae in that same work. We concur. Gollincarcinus and Lessinioplax are placed within the Pilumnidae based upon their possession of a smooth carapace; entire frontal, supraorbital, and anterolateral margins; a highly vaulted carapace, especially anteriorly; broad fronto-orbital width; and hexagonal carapace. Magyarcarcinus and allied members of the Goneplacidae admittedly also exhibit many of these features, but they are ovate and are not as highly vaulted. Description of the sternum and abdomen of Gollincarcinus and Lessinioplax would help to confirm their family placement.

Family Pseudorhombilidae Alcock, 1898

Included fossil genera. Nanoplax Guinot, 1967a (also extant); Pseudorhombila H. Milne Edwards, 1837 (also extant).

\section{Occurrence. Miocene - Recent.}

Diagnosis. Carapace hexagonal, wider than long, $L / W$ ranging from $0.72-0.76$, position of maximum width about 40-55 percent the distance posteriorly on carapace; carapace flattened, regions moderately well-marked to weakly defined; front bilobed, ranging from 26-32 percent maximum carapace width; orbits with two fissures or notches, orbital rim sinuous, convex between fissures, marked protuberance on inner orbital rim; fronto-orbital width about 5359 percent maximum carapace width; anterolateral margin with 3-5 spines including outer-orbital spine; sternum wide, tiny portion of sternite 8 visible adjacent to articulation condyle of coxa of fifth pereiopod, visible in posterior or dorsal view; male abdominal somites 1 and 2 not covering entire space between fifth pereiopods, somite 3 usually touching coxa of fifth pereiopod; male abdominal somites 3-5 fused, often weakly, sutures may be quite obvious. Diagnosis based in part on descriptions and observations from Rathbun (1918), Guinot (1969), Hendrickx (1998) and Schweitzer and Karasawa (2004: 81).

Family Trapeziidae Miers, 1886

Included fossil genera. Archaeotetra Schweitzer, 2005b; Eomaldivia Müller and Collins, 1991; Tetralia Dana, 1851c (also extant); Trapezia Latreille, 1828 (also extant).

\section{Occurrence. Eocene - Recent.}

Diagnosis. Carapace cordate, not much wider than long, length averaging about 86 percent maximum carapace width, position of maximum width about half the distance posteriorly on carapace; carapace regions not defined; front weakly bilobed, four-lobed, serrate, or nearly straight, without median notch, about half maximum carapace width; orbits deeply excavated, positioned at corners of frontal margin of carapace, directed anterolaterally, fronto-orbital width about 90 percent or more maximum carapace width; anterolateral margins short, usually oriented nearly perpendicular to frontal margin of carapace or oriented at very high angle to frontal margin, entire or with one or two spines. Basal antennal article slender; efferent channels defined by well-developed endostomial crests; merus of third maxilliped shorter than ischium, about as wide as long; endopod of second maxilliped composed of four separate segments. Sternites 1 and 2 fused into triangle, sternal suture 2/3 present or absent. Male abdomen with somites 3-5 fused with visible sutures or with all somites free. Male gonopod 1 slender or stout, sinuous or straight, with pointed or rounded tip; male gonopod 2 stout or slender, curved, tip spoon-shaped. Chelae unequal, smooth or weakly granular, merus of cheliped extending beyond carapace margins when folded; pereiopods 2-5 "with dactylo-propodal articulation formed by rounded prolongation of propodal lateral margin sliding against and beneath a projecting button situated proximally on lateral margin of dactylus" (Davie, 2002: 493) (After Schweitzer, 2005b: 627). 
Family Xanthidae MacLeay, 1838 sensu stricto

Included fossil genera. Actaea De Haan, 1833 (also extant); Actaeops Portell and Collins, 2004; Atergatis De Haan, 1833 (also extant); Banareia A. MilneEdwards, 1869 (also extant); Chlorodiella Rathbun, 1897 (also extant); Cyclodius Dana, 1851a (also extant) (=Phymodius A. Milne-Edwards, 1863); Cycloxanthops Rathbun, 1897 (also extant); Cymo De Haan, 1833 (also extant); Demania Laurie, 1906 (also extant); Etisus H. Milne Edwards, 1834 (also extant); Forestia Guinot, 1976 (also extant); Glyptoxanthus A. Milne-Edwards, 1879 (also extant); Haydnella Müller, 1984; Heteractaea Lockington, 1877 (also extant); Hypocolpus Rathbun, 1897 (also extant); Lachnopodus Stimpson, 1858 (also extant); Leptodius A. Milne-Edwards, 1863 (also extant); Liagore De Haan, 1833 (also extant); Liomera Dana, 1851a (also extant); Lipaesthesius Rathbun, 1898 (also extant); Lybia H. Milne Edwards, 1834 (also extant); Macromedaeus Ward, 1942 (also extant); Medaeops Guinot, 1967a (also extant); Medaeus Dana, 1851a (also extant); Megamia Karasawa, 1993; Metopoxantho De Man, 1904; Monodaeus Guinot, 1967a (also extant); Neoliomera Odhner, 1925 (also extant) (=Neomeria Hu and Tao, 1996); Palaeotrichia Guinot, 1976; Palaeoxanthops Karasawa, 1993; Paraxanthias Odhner, 1925 (also extant); Paraxanthodes Guinot, 1967b (also extant); Phlyctenodes A. Milne-Edwards, 1862; Pilodius Dana, 1852 (also extant); Sculptoplax Müller and Collins, 1991; Xanthias Rathbun, 1897 (also extant); Xantho Leach, 1814 (also extant); Xanthodius Stimpson, 1859 (also extant); Zalasius Rathbun, 1897 (also extant); Zosimus Leach in Desmarest, 1823 (also extant).

Occurrence. Eocene - Recent.

Diagnosis. Carapace hexagonal or transversely ovate; carapace length/width falling into two groups, length either about two-thirds to three quarters or 90-100 percent maximum carapace width, widest two-thirds to three quarters the distance posteriorly except in some Xanthinae and Polydectinae in which position of maximum width is before the midlength; regions usually well-defined but dorsal carapace can be smooth; frontal margin bilobed, with axial notch, ranging from one-quarter to about 40 percent maxi- mum carapace width; fronto-orbital width generally about half to two-thirds maximum carapace width; anterolateral margins with between 2 and 6 lobes or spines; anterolateral margin well-differentiated from posterolateral margin, anterolateral margin often tightly convex; posterolateral margin often concave. Epistome with ridges that define efferent branchial canals absent or only on posterior portion of buccal cavity, not intercepting anterior part of buccal frame. Sternum narrow, sternite 8 not visible ventrally. Male abdomen with somites 3-5 fused, sutures may be visible. Male genital openings coxal. Male gonopod 1 slender, curved or sinuous, simple apex without complex lobes or folds, with long setae distally or subdistally; gonopod 2 short, less than 25 percent length of gonopod 1. Cheliped fingers typically black; chelae subequal or heterochelous, may have spoonshaped tips. Chelipeds much stouter than pereiopods 2-5. Modified after Davie (2002).

Discussion. Števčić (2005) separated the Xanthidae sensu stricto into numerous subfamilies and tribes. Evaluation of the validity and composition of these is beyond the scope of this paper; we have considered them simply as members of the family.

Rathbun (1945) referred a species to Carpilodes Dana, 1851a, which has subsequently been made a junior synonym of Atergatis; thus, Carpilodes sublensis Rathbun, 1945, is now referred to Atergatis. Interestingly, the notes of one of us (CES) suggest that the holotype of that species (USNM 498416) possibly could be a damaged specimen of Atergatis laddi Rathbun, 1945, (holotype USNM 498415), named in the same paper.

Neomeria Hu and Tao, 1996, is herein considered as a junior synonym of Liomera based upon its carapace shape and groove pattern.

Superfamily Xanthoidea MacLeay, 1838, incertae sedis

Included fossil genera. Actaeites Müller and Collins, 1991; Actaeopsis Carter, 1898; Caprocancer Müller and Collins, 1991; Carpiliopsis Fischer-Benzon, 1866; Colpocaris Von Meyer, 1863; Creticarcinus Withers, 1928; Cretichlorodius Fraaye, 1996; Cyclocorystes Bell, 1858; Eoplax Müller and Collins, 1991; Eoxanthias Hu and Tao, 1996; Gemmacarcinus Müller and Collins, 1991; Martinocarcinus Böhm, 
1922; Megaxantho Vega, Feldmann et al., 2001; Paraxanthosia Müller and Collins, 1991; Pilumnomimus Müller and Collins, 1991; Pregeryona Hu and Tao, 1996; Prochlorodius Müller and Collins, 1991; Santeella Blow and Manning, 1996; Styrioplax Glaessner, 1969; Syphax A. Milne-Edwards, 1864; Thelecarcinus Böhm, 1891; Thelphusograpsus Lőrenthey, 1902; Wanga Hu and Tao, 1996.

Discussion. The description of Actaeopsis contains similarities to members of the Tumidocarcinidae or the Palaeoxanthopsidae; however, examination of type material will be necessary to confirm its identity. The various taxa described by Müller and Collins (1991) are poorly preserved but retain features characteristic of the Xanthoidea sensu stricto. Actaeites appears to be most similar to Titanocarcinus, and Pilumnomimus and Prochlorodius may be most similar to Glabropilumus sensu lato (see Galil and Takeda, 1988). However, both of the latter fossil genera also have similarities with members of the Panopeidae and Euryplacidae. Thus, examination of more complete specimens will be necessary to confirm their family-level placement. The dorsal carapace of Martinocarcinus is quite damaged although the sternum is preserved; examination of type material will be necessary to confirm its identity. Megaxantho was originally placed within the Xanthidae; it was later suggested that it more closely resembled the Cancridae based upon the conformation of the anterolateral spines (D. Guinot, personal commun.). Most recently, Števčić (2005) erected a new family Megaxanthidae of the Goneplacoidea incertae sedis for it. Better preserved material would help clarify the familial placement of Megaxantho. Placement of Styrioplax, Syphax, Thelphusograpsus, and the genera erected by $\mathrm{Hu}$ and Tao (1996) must await examination of type material.

Thelecarcinus may well be referrable to the Hepatidae, based on the shape of the carapace, ornamentation, and the conformation of the anterolateral margins (Böhm, 1891, pl. 1, fig. 3); however, formal placement must await examination of type material. Creticarcinus and Carpiliopsis may be junior synonyms of Caloxanthus, referred below to the Etyidae Guinot and Tavares, 2001; however, Creticarcinus has better defined and more tumid dorsal carapace regions (Withers, 1928, pl. XIII, fig. 4), and Carpiliopsis lacks a distinct cervical furrow and granular ornamentation (Fischer-Benzon, 1866, pl. II, fig. 1) as seen in Caloxanthus. Type material needs to be examined to formally place these two genera within a family.

Superfamily Eriphioidea MacLeay, 1838

Included families. Platyxanthidae Guinot, 1977; Hypothalassiidae Karasawa and Schweitzer new family; Pseudoziidae Alcock, 1898; Eriphiidae MacLeay, 1838; Oziidae Dana, 1851a (= Menippidae Ortmann, 1893; see Schweitzer, 2003a, for discussion of synonymy).

\section{Occurrence. Eocene - Recent.}

Diagnosis. Carapace hexagonal or ovate, wider than long, maximum carapace length 60-75 percent maximum carapace width, widest about half to twothirds the distance posteriorly on carapace; dorsal carapace regions moderately or weakly defined; frontal margin bilobed or quadrilobed excluding inner-orbital spines, frontal margin about 20-30 percent maximum carapace width except in Eriphiidae (50 percent) and Dacryopilumninae of Oziidae (70 percent); fronto-orbital width about one-third to half maximum carapace width except in Eriphiidae (70 percent) and Dacryopilumninae of Oziidae (90 percent); anterolateral margins with four spines or lobes, or entire, or with a variable number of spines; anterolateral margin distinct from posterolateral margin. Buccal frame anteriorly tapered, trapezoidal. Sternum narrow; sternal sutures 4/5 and 5/6 interrupted but uninterrupted in female of Menippinae; sternal sutures 6/7 and 7/8 complete; all male abdominal somites free, movable; male abdomen fills space between coxae of fifth pereiopods. Male gonopod 1 stout, straight or weakly curved or long and slender; gonopod 2 as long as or longer than gonopod 1, with a short, developed, long, or very long flagellum. Chelipeds at least weakly heterochelous, sometimes markedly so. (In part modified after Ng and Wang, 1994; Davie, 2002).

Discussion. Rice (1981, 1983) suggested that the platyxanthid Homalaspis and two eriphiids, Eriphia and Ozius, had the most primitive zoeal features within the xanthoids and that the other xanthoids, the cancroids, and the portunoids may have evolved from 
them. Števčić (1998) considered that the Eriphiidae had the most primitive characters in terms of adult morphology within the Xanthoidea. However, in the present analysis, the Eriphiidae is a rather derived group within the Xanthoidea.

The Platyxanthidae is the sister to the remainder of the clade. The Eriphiidae sensu lato is polyphyletic. The polyphyly of the Eriphiidae sensu lato was previously suggested by Coelho and Coelho Filho (1993), and they included the Menippinae with Menippe within the Xanthidae and placed Eriphia in its own family Eriphiidae. More recently, Ng et al. (2001) recognized four eriphiid subfamilies, Eriphiinae including only Eriphia; Oziinae including Ozius, Epixanthus, Epixanthoides Balss, 1935, Lydia Gistel, 1848, Baptozius Alcock, 1898, Bountiana Davie and Ng, 2000, and Eupilumnus Kossmann, 1877 = Globopilumnus Balss, 1933; Menippinae including Hypothalassia, Menippe, Myomenippe, Sphaerozius, and Pseudocarcinus H. Milne Edwards, 1834; and Dacryopilumninae including only Dacryopilumnus, based upon characters of the carapace, antennae, orbits, and gonopod 2. Davie (2002) added Ruppellioides A. Milne-Edwards, 1867, to the Menippinae. Sakai (2004) synonymized the Menippinae with the Oziinae and placed Eupilumnus and Hypothalassia under the Eriphiinae. Poore (2004) considered Eupilumnus as a member of the Oziinae and placed Hypothalassia within the Menippinae. Števčić (2005) recognized three subfamilies, Eriphiinae, Platyxanthinae, and Dacryopilumninae within the Eriphiidae. Thus, the classification of the Eriphiidae sensu lato has been problematic. We follow Ng et al. (2001) in the arrangement of genera within subfamilies and families, with the exception that Hypothalassia is herein placed within a monotypic family.

Family Platyxanthidae Guinot, 1977

Included fossil genera. Pelaeus Eydoux and Souleyet, 1842 (fossil and extant); Platyxanthus A. Milne Edwards, 1863 (fossil and extant).

\section{Occurrence. Eocene - Recent.}

Diagnosis. Carapace hexagonal, wider than long, length about two-thirds maximum carapace width, ranging from 0.63 to 0.70 ; front with four spines excluding inner-orbital projection or nearly straight with central notch, frontal width about 0.2 maximum carapace width, ranging from 0.13 to 0.24 ; orbits with fissures, usually two, fronto-orbital width about 0.36 maximum carapace width, ranging from 0.33 to 0.38. Anterolateral margins moderately convex; many possible configurations, either with numerous blunt spines, or with broad, bluntly spinose lobes separated by fissures, or with broad, entire lobes separated by fissures; last anterolateral spine extending posteriorly and axially onto dorsal carapace; angle of posterolateral to posterior margin about 38 degrees; posterior width about 0.38 maximum carapace width, ranging from 0.36 to 0.41 . Carapace regions poorly defined, protogastric and hepatic regions weakly inflated. Endostomial ridges absent. Chelae stout, smooth, coxa of first pereiopod articulating with merus, merus not fused to basis-ischium. Sternum relatively straight and narrow or rather wide, sternal sutures 4/5 and 5/6 not continuous, 6/7 and 7/8 continuous; suture between sternites 2 and 3 complete; suture between sternites 3 and 4 deep, well developed laterally but becoming a shallow groove axially, merging with long groove extending anteriorly from sterno-abdominal cavity to form deep, $Y$ shaped groove pattern; sternite 8 not visible in ventral view. All male abdominal somites free, male abdomen barely reaching or not reaching level of posterior margin of coxae of first pereiopods, covering entire space between coxae of fifth pereiopods. Male gonopod 1 stout; male gonopod 2 long, with an elongated proximal article and a developed flagellum (after Schweitzer, 2005a: 287).

Family Hypothalassiidae new family

Type and sole included genus. Hypothalassia Gistel, 1848.

\section{Occurrence. Recent.}

Diagnosis. Carapace hexagonal, wider than long, maximum carapace length about 85 percent maximum carapace width; front bilobed, medially notched, projecting anteriorly, with numerous supplementary spines; orbit not closed; inner-orbital spine well developed; frontal width about one-quarter maximum carapace width; orbits spinose, with two fissures; fronto-orbital width about half maximum carapace width. Basal article of antenna not reaching to front. 
Endostomial ridges present. Anterolateral margins moderately convex, spinose. Posterolateral margin nearly straight, tuberculate. Posterior margin about half maximum carapace width. Carapace regions well defined, ornamented with spines anteriorly and posterolaterally. Chelipeds heterochelous, spinose, fingers black. Pereiopods 2-5 spinose, with corneous dactyl tips. Thoracic sternum moderate in width; sternal sutures 4/5 and 5/6 not continuous; sternite 8 not visible in ventral view. Male abdomen reaching to posterior end of coxa of pereiopod 1; all male abdominal somites free, movable, filling entire space between coxae of fifth pereiopods. Male gonopod 1 stout, gently curved; male gonopod 2 longer than 1 , with long flagellum.

Discussion. Hypothalassia previously had been placed in the subfamily Menippinae (Ng et al., 2001; Davie, 2002), the Eriphiinae (Sakai, 2004), or simply within the Eriphiidae sensu lato (Koh and Ng, 2000). Our analysis shows that Hypothalassia belongs to an independent lineage within the Eriphioidea. The Hypothalassiidae lack a weakly protruded front (5-1) and the absence of upper orbital fissures (7-1), which are diagnostic characters of the Pseudoziidae, Eriphiidae, and Oziidae. The Pseudoziidae have a short male gonopod 2 with a short flagellum, while the Hypothalassiidae have a long gonopod 2 with a long flagellum. The Hypothalassiidae, Eriphiidae, Oziidae, and Platyxanthidae have a long male gonopod 2 with a long flagellum. However, the Oziidae are characterized by having a filamentous flagellum. In the Eriphiidae, the fronto-orbital width is about $70 \%$ of the maximum carapace width and the orbit is completely closed, but in the Hypothalassiidae, the fronto-orbital width is about $50 \%$ of the maximum carapace width and the orbit is open. The Hypothalassiidae differ from the Platyxanthidae because in the Hypothalassiidae, the carapace and all pereiopods are ornamented with spines and tubercles, the carapace regions are well defined, a Y-shaped sternal groove pattern is absent, the suture between the thoracic sternites 3 and 4 is shallow and indistinct, and episternal markings on thoracic sternite 4 are absent. Thus, at this time the Hypothalassiidae is an independent, monotypic lineage for which there is no recognized fossil record; however, ongoing investigation of Titanocarcinus aculeatus Busulini et al., 1984, may result in its placement within the family.
Family Pseudoziidae Alcock, 1898

Included fossil genera. Archaeozius Schweitzer, 2003a; Euryozius Miers, 1886 (also extant); Priabonocarcinus Müller and Collins, 1991; Santeexanthus Blow and Manning, 1996.

\section{Occurrence. Eocene - Recent.}

Diagnosis. Carapace usually ovate, wider than long, flattened, maximum carapace length about 65-75 percent maximum carapace width; regions moderately, poorly or not defined, grooves defining cardiac and other gastric regions weakly developed, epigastric regions may be weakly developed but often indistinct. Front nearly straight, bilobed, or weakly quadri-lobed, axially notched, can be markedly deflexed, all lobes extending the same distance anteriorly, front about 30 percent maximum carapace width in most taxa but 60 percent in Planopilumnus Balss, 1933; orbits shallow, ovoid, weakly rimmed; frontoorbital width about half maximum carapace width in most taxa but up to 80 percent in Planopilumnus. Anterolateral margin entire, with small spines at anterolateral corner, or lobed with shallow notches or fissures separating lobes; extending to about midlength or just anterior to it. Posterolateral margin sinuous or nearly straight, angle of posterolateral to posterior margin 40-45 degrees. Posterior margins 30 percent to half maximum carapace width except much wider in Planopilumnus. All male abdominal somites free; male abdomen sometimes not entirely occupying space between coxae of fifth pereiopods; sternite 8 sometimes visible ventrally. Fusion of the basis-ischium with merus of major cheliped sometimes present, incomplete, remnants of suture visible; coxa appearing to articulate directly with merus; fingers of chelae black (modified from Crosnier and Guinot, 1969; Schweitzer, 2003a: 1112). Sternites 1/2 fused, suture not visible; sternal suture 2/3 relatively deep; sternal suture $3 / 4$ medially interrupted; sternal sutures 4/5 and 5/6 incomplete, 6/7 and 7/8 complete. Antenna not lodged in orbital hiatus, instead, second and third segments placed in rounded cleft formed by front and supraorbital spine. Male gonopod 1 long, slender or moderately stout, with numerous short spines; male gonopod 2 short, straight, about 30 to 50 percent the length of gonopod 1, flagellum short to very short. (After Ng and Wang, 1994; Davie, 2002; Ng and Liao, 2002). 
Family Eriphiidae MacLeay, 1838

Included genus. Eriphia Latreille, 1817 (also extant).

Occurrence. Oligocene - Recent.

Diagnosis. Carapace hexagonal, wider than long; regions distinct, with ridges and granules especially on anterior regions; front axially notched, bordered on either side of notch by straight segment, notch just proximal to each orbit, front about half maximum carapace width; orbits closed, strongly rimmed, directed anterolaterally, fronto-orbital margin about 70 percent maximum carapace width; antennae placed at some distance from orbits and antennules; anterolateral margin with variable number of spines. Sternum narrow; sternal sutures $4 / 5$ and $5 / 6$ incomplete, 6/7 and 7/8 complete; male sternite 8 not visible (USNM 48565) or barely visible (RO 3976, specimen figured in Glaessner, 1969, fig. 326.7); male abdomen covers space between coxae of fifth pereiopods. Chelipeds heterochelous, fingers of chelipeds black. Male gonopod 1 stout; male gonopod 2 long with long flagellum. (In part after Davie, 2002).

Family Oziidae Dana, 1851a

Included subfamilies. Dacryopilumninae Serène, 1984; Menippinae Ortmann, 1893; Oziinae Dana, 1851a. The latter two have a known fossil record.

Included fossil genera. Menippe De Haan, 1833 (also extant) (Menippinae); Ozius H. Milne Edwards, 1834 (also extant) (Oziinae); Pseudocarcinus H. Milne Edwards, 1834 (also extant) (Menippinae).

Diagnosis. Carapace hexagonal or ovate, wider than long, maximum length 60-75 percent maximum carapace width, widest about half to two-thirds the distance posteriorly on carapace; dorsal carapace regions moderately or weakly defined; frontal margin bilobed or quadri-lobed excluding inner-orbital spines, frontal margin about 20-30 percent maximum carapace width except in Dacryopilumninae (70 percent); orbits opened medially or incompletely closed (Menippinae and Oziinae) or completely closed (Dacryopilumninae); fronto-orbital width about onethird to half maximum carapace width except in
Dacryopilumninae (90 percent); anterolateral margins with four or five spines or lobes, or entire, or with a variable number of spines; anterolateral margin distinct from posterolateral margin.

Antennae positioned close to antennules and orbits (Menippinae and Oziinae) or at a great distance from them (Dacryopilumninae). Buccal frame anteriorly tapered, trapezoidal; sternum narrow; female sternal sutures 4/5 and 5/6 interrupted medially (Oziinae) or complete and nearly parallel (Dacryopilumninae and Menippinae); all male abdominal somites free, movable; male abdomen fills space between coxae of fifth pereiopods. Male gonopod 1 stout, straight or weakly curved; male gonopod 2 as long as or longer than 1, with long, filamentous flagellum. Chelipeds usually heterochelous; large molariform tooth on fixed finger of major cheliped (Menippinae and Oziinae). (In part modified after Davie, 2002; Ng and Wang, 1994).

Superfamily Progeryonoidea Števčić, 2005

Included family. Progeryonidae Števčić, 2005.

Diagnosis. As for the family.

Family Progeryonidae Števčić, 2005

Type and sole included genus. Progeryon Bouvier, 1922.

Occurrence. Recent.

Diagnosis. Carapace subquadrate, about as long as wide or slightly wider than long, widest about twothirds the distance posteriorly on carapace, flattened transversely and longitudinally; dorsal carapace regions moderately defined. Front nearly straight or bilobed, medially notched, about 25-35 percent maximum carapace width; fronto-orbital width about half maximum carapace width; upper orbital margin rimmed, sometimes with weak fissure. Anterolateral margin arcuate, entire or lobate, with short lateral spine; posterolateral margin straight or weakly sinuous, much longer than anterolateral margin; posterior margin about half maximum carapace width, medially concave.

Endostomial ridges present, strong. Thoracic sternum wide. Anterior end of the sterno-abdominal 
cavity not reaching to anterior of thoracic sternite 4; sternite 1 and 2 completely fused; suture between 2 and 3 complete; suture between 3 and 4 deep, complete; anterior of sternite 4 with median sulcus, together with suture 3/4 forming Y-shaped groove pattern on sternum; sutures $4 / 5,5 / 6$, and $6 / 7$ medially interrupted; suture between 7/8 complete; sternite 8 not visible in ventral or posterior view; all male abdominal somites free; male abdomen filling entire space between coxae of pereiopods 5 .

Chelipeds heterochelous, with dark-colored fingers; major cheliped with large, molar basal tooth on occlusal surface of dactylus; pereiopods 2-5 long; dactylus with corneous tips. Male gonopod 1 stout, nearly straight, with a simple apex; gonopod 2 longer than 1 with long flagellum.

Discussion. Števčić (2005) erected a new tribe Progeryonini for Progeryon and placed it within the Geryonidae. In the present analysis, Progeryon cannot be accommodated in any known families of the Goneplacoidea and Portunoidea; thus, the Progeryonini is treated as a separate family which belongs within a monophyletic group together with the known families of the Goneplacoidea and Portunoidea. However, the sister-group relationships among the Progeryonidae, Goneplacoidea, and Portunoidea cannot be resolved. Therefore, the Progeryonidae is here given superfamily status.

The Progeryonidae differs from the families of the Goneplacoidea, as defined here, by the possession of a Y-shaped groove pattern on the male thoracic sternum, the male sterno-abdominal cavity not reaching to the anterior of thoracic sternite 4 in males, absence of a posterolateral prolongation of male episternite 7 , and the possession of a complete sternal suture 7/8. The Progeryonidae is readily distinguished from the families of the Portunoidea because the Progeryonidae possess a Y-shaped groove pattern on the male thoracic sternum, all male abdominal somites are free, and the male gonopod 1 is nearly straight.

Manning and Holthuis (1989) suggested that Progeryon and Paragalene, previously assigned to the Geryonidae, might well belong to a new family. However, Paragalene differs from Progeryon because Paragalene has a carapace that is much wider than long and has frontal spines and well separated anterolateral lobes, and the male gonopod 1 is rather slender and is curved. Therefore, Paragalene might be assigned to the Mathildellidae, but the known members of the Mathildellidae lack frontal spines as seen in Paragalene. Detailed examination of the thoracic sternal characters of Paragalene will be necessary to confirm its familial placement.

Superfamily Goneplacoidea MacLeay, 1838

Included families. Carinocarcinoididae Karasawa and Kato, 2003a; Chasmocarcinidae Serène, 1964; Euryplacidae Stimpson, 1871; Goneplacidae MacLeay, 1838; Hexapodidae Miers, 1886; Trogloplacidae Guinot, 1986.

Diagnosis. Carapace transversely rectangular, ovate, or trapezoidal; generally flattened transversely and longitudinally; dorsal carapace regions weakly defined or indistinct; front weakly protruded, straight, sometimes with median notch or projection; upper orbital margin with or without fissures, fronto-orbital width often very broad; buccal frame quadrangular; anterolateral margin may be entire or spined, sometimes merging with and indistinct from posterolateral margin.

Anterior end of the sterno-abdominal cavity reaching to the anterior of thoracic sternite 4; sternite 4 without medial sulcus; all thoracic sutures interrupted; well-developed posterolateral prolongation of male episternite 7 , sternite 8 visible in ventral or posterior view; male abdominal somites free or 3-5 fused and immovable; male abdomen may or may not fill entire space between coxae of fifth pereiopods; fifth pereiopod and sternite 8 may be much reduced so as to be absent in ventral view (Hexapodidae).

Chelipeds usually heterochelous, usually without dark-colored fingers; absence of corneous tips on pereiopods 2-5, pereiopods 2-5 generally much less robust than cheliped. Male gonopod 1 stout, sinuous, or curved, usually with a simple apex; gonopod 2 long or short (after Karasawa and Kato, 2003a).

\section{Occurrence. Cretaceous - Recent.}

Discussion. The Goneplacoidea as herein constituted is a heterogeneous group, composed of mostly flattened crabs with weakly protruded fronts and ovate sterna. Within the group, however, there is considerable variation and there is a history of treatment of the various subfamilies as family-level taxa. Guinot 
(1977) first treated the Hexapodinae, previously placed under the Goneplacidae Balss (1957), as a distinct family and assigned the family to its own superfamily Hexapodoidea within the section Thoracotremata. Manning and Holthuis (1981) treated the Hexapodidae as a family closely related to the Goneplacidae. Following the work of Bowman and Abele (1982), most workers placed the Hexapodidae within the Xanthoidea sensu lato. Guinot and Richer de Forges (1997) supported the placement of the Hexapodidae within the Heterotremata based upon the larval evidence of Pereyra Lago (1988).

D'Udekem d'Acoz (1999) raised the Euryplacinae and Carcinoplacinae to full family status and included both families in the superfamily Goneplacoidea. Števčić (in Martin and Davis, 2001) suggested that the Euryplacinae be elevated to family status, and Glaessner and Secretan (1987) and Guinot et al. (2002) gave the Carcinoplacinae full family status. Davie (2002) elevated the Trogloplacinae to full family status, although Davie and Guinot (1996) and Karasawa and Kato (2003a, b) pointed out that the Trogloplacinae has close affinities with the Chasmocarcininae. Thus, our recognition of these subfamilies as families has clear precedent.

Števčić (2005) erected two new families and one new subfamily for extinct genera within the Goneplacoidea sensu Števčić (2005). The Amydrocarcinidae Števčić, 2005, embraces Amydrocarcinus Schweitzer et al., 2002, which we herein consider to be a member of the Goneplacidae within the Goneplacoidae. The Megaxanthidae Števčić, 2005, was erected to embrace the poorly preserved Megaxantho Vega et al., 2001. The sole specimen of the genus is too poorly preserved to form the basis of a new family, and we regard it herein as Xanthoidea incertae sedis until better preserved, more complete material can be collected. Števčić (2005) also erected a separate subfamily to embrace Icriocarcinus Bishop, 1988, the Icriocarcininae Števčić, 2005. We regard that genus as a member of the Goneplacidae based upon its wellpreserved sternal, abdominal, and dorsal carapace features.

Family Carinocarcinoididae Karasawa and Kato, 2003a

Included fossil genera. Bicarinocarcinus Glaessner and Secretan, 1987; Carinocarcinoides Karasawa and Fudouji, 2000.

\section{Occurrence. Eocene - Miocene.}

Diagnosis. Carapace wider than long, length ranging from 70 to 90 percent maximum carapace width, widest at position of last anterolateral spine or just anterior to it, 40-50 percent the distance posteriorly on carapace; dorsal carapace with more or less defined dorsal regions, epibranchial regions and sometimes other regions transversely inflated to form carinae; front straight, without median notch, between onequarter and one-third maximum carapace width; notch between frontal margin and supraorbital angle indistinct; upper orbital margin without fissures, frontoorbital width between two-thirds and three-quarters maximum carapace width; anterolateral margin with two spines excluding outer-orbital spine; merus of maxilliped 3 subquadrate, much longer than ischium; male abdomen filling entire space between coxae of pereiopods 5, with somites 3-5 fused; thoracic sternum wide; sternal sutures 4/5, 5/6, and 6/7 apparently interrupted; sternite 7 with posterolateral prolongation; sternite 8 visible in ventral view, overlying posterior portion of sternite 7; sterno-abdominal cavity reaching anterior of sternite 4; fingers of chelipeds long, elongate, not dark in color (after Glaessner and Secretan, 1987: 7; Karasawa and Kato, 2003a: 142).

Family Chasmocarcinidae Serène, 1964

Included fossil genera. Chasmocarcinus Rathbun, 1898 (also extant); Collinsius Karasawa, 1993; Falconoplax Van Straelen, 1933; Gillcarcinus Collins and Morris, 1978; Mioplax Bittner, 1884; Orthakrolophos Schweitzer and Feldmann, 2001.

\section{Occurrence. Eocene - Recent.}

Diagnosis. Carapace rectangular or trapezoidal, wider than long, length about 70-85 percent maximum carapace width; carapace regions poorly defined but may have swellings or ridges; front straight or weakly flared, with medial notch, about 40 percent maximum carapace width, notch between frontal margin and supraorbital margin indistinct; orbits usually small, orbital margins entire, fronto-orbital width about half maximum carapace width, eyestalk short; anterolateral margin entire or spined. Basal antennular segment very swollen, completely filling antennular fossa, excluding flagellum which thus 
cannot be folded and is unprotected (Davie, 2002: 196, 503). Buccal frame narrowing anteriorly; third maxillipeds not closing the buccal cavity; merus of third maxilliped suboval, about as long as ischium, palp more or less distal. Sternum wide, all sutures interrupted; sterno-abdominal cavity reaching anterior of sternite 4; sternite 8 visible in ventral view, overlying posterior part of sternite 7; open groove between sternites 7 and 8 may be covered with supplementary plate. Male abdomen not entirely filling space between coxae of fifth pereiopods; male abdominal somites 3-5 fused. Male gonopod 1 stout, sinuous, with simple apex; gonopod 2 noticeably shorter than gonopod 1, flagellum much shorter than peduncle. Dactyli of pereiopods 2-5 sickle-shaped with setae (after Schweitzer and Feldmann, 2001; Davie, 2002: 196, 503; Karasawa and Kato, 2003a).

Family Euryplacidae Stimpson, 1871

Included fossil genera. Chirinocarcinus Karasawa and Schweitzer, 2004; Chlinocephalus Ristori, 1886; Corallicarcinus Müller and Collins, 1991; Eucrate De Haan, 1835 (also extant); Euryplax Stimpson, 1859 (also extant); Orbitoplax Tucker and Feldmann, 1990; Paleopsopheticus Hu and Tao, 1996; Simonellia Vinassa de Regny, 1897; Stoaplax Vega, Cosma et al., 2001; Viaplax Karasawa and Kato, 2003a.

\section{Occurrence. Paleocene - Recent.}

Diagnosis. Carapace subquadrilateral, rectangular, or trapezoidal, wider than long, length usually about 80 percent maximum width; regions moderately to poorly defined; front generally straight with axial notch, from one-quarter to one half maximum carapace width but usually about one-third; orbits generally large, with orbital fissures, orbits open or closed due to a variety of possible morphologies (Davie, 2002: 198); fronto-orbital margin at least two-thirds maximum carapace width, usually about 80 percent but can be as much as 100 percent; eye-stalk can be short or long, apparently well-calcified as it can be fossilized; basal article of antenna reaching front; merus of third maxilliped subquadrate, much longer than ischium; anterolateral margin with three or so spines, not well-differentiated from posterolateral margin; posterolateral reentrant well-developed.
Sternum wide; sterno-abdominal cavity reaching anterior of sternite 4; all sternal sutures interrupted, sternite 8 barely visible in ventral view or quite obvious. Male abdomen with all somites free and movable, somites 4-6 much narrower than somite 3, telson usually longer than wide, male abdomen filling entire space between coxae of fifth pereiopods. Male gonopod 1 long and thin, narrow apically, ornamented with small tubercles; gonopod 2 very short. Chelipeds isochelous or weakly heterochelous; dactyli of pereiopods 2-5 usually styliform, with or without setae. (In part after Davie, 2002, and Karasawa and Kato, 2003a).

Discussion. Simonellia was described as being very similar to Chlinocephalus, differing from it only in minor aspects of the carapace shape and ornamentation. Simonellia differs from some other members of the family in having a front that is not produced. However, we ally it with Chlinocephalus in the Euryplacidae until type material can be examined. Karasawa and Kato (2003a) synonymised Paleopsopheticus with Psopheticus. However, herein Paleopsopheticus is a distinct genus and is placed within the Euryplacidae based upon its broad, straight front with small medial notch; broad orbits; broad fronto-orbital width, and anterolateral margins with few spines.

Family Goneplacidae MacLeay, 1838 (= Carcinoplacinae H. Milne Edwards, 1852; see Karasawa and Kato, 2003a)

Included fossil genera. Amydrocarcinus Schweitzer et al., 2002; Carcinoplax H. Milne Edwards, 1852 (also extant); Goneplax Leach, 1814 (also extant); Icriocarcinus Bishop, 1988; Magyarcarcinus Schweitzer and Karasawa, 2004; Ommatocarcinus White, 1852 (also extant); Psopheticus Wood-Mason, 1892 (also extant).

Occurrence. Late Cretaceous - Recent.

Diagnosis. Carapace hexagonal, transversely ovate, or subquadrate; wider than long, sometimes markedly so, position of maximum width well in advance of midlength; front straight, without median notch, sometimes with medial projection; upper orbital margins entire; notch between frontal margin and 
orbits indistinct; fronto-orbital width variable, ranging from two-thirds to 100 percent maximum carapace width; anterolateral margin with one to three spines excluding outer-orbital spines or entire. Eyestalks short or long, sometimes extremely long; merus of third maxilliped subquadrate, longer than ischium. Male abdomen filling entire space between coxae of fifth pereiopods; all male abdominal somites free. Sternum broad, ovate; sternite 8 not visible in ventral view; sterno-abdominal cavity reaching anterior of sternite 4 . Chelipeds robust compared to other pereiopods, without black tips on fingers, usually with lateral spine on carpus; dactyli of pereiopods 2-4 styliform or spatulate, with or without setae. Male gonopod 1 stout, sinuous, usually with truncated apex; male gonopod 2 long, usually with long flagellum (after Karasawa and Kato, 2003a).

Family Hexapodidae Miers, 1886

Included fossil genera. Goniocypoda Woodward, 1867; Hexapinus Manning and Holthuis, 1981 (also extant); Hexapus De Haan, 1833 (also extant); Palaeopinnixa Vía, 1966; Stevea Manning and Holthuis, 1981 (also extant).

Occurrence. Late Cretaceous - Recent.

Diagnosis. Carapace rectangular or rarely trapezoidal; wider than long, length averages about 70 percent maximum carapace width; anterolateral and posterolateral margins confluent, often with ridge paralleling anterolateral portion, posterolateral reentrant well-defined; regions poorly or not defined; lateral margins steep. Front narrow and widest distally, axially sulcate, usually extending at least weakly beyond orbits, not deflexed; orbits usually rimmed, upper margin sinuous, entire; straight anterior margin of carapace only partially occupied by orbits except in Goniocypoda; fronto-orbital width about half maximum carapace width but ranges from about 30 - 60 percent; fronto-orbital width to posterior width ratio averages 60 percent, ranging from 30 to 80 percent; posterior width 70-90 percent maximum carapace width; antennules folded transversely, antennae small; eyes small, usually movable but can be fixed. Third maxilliped ranging from broad to slender; propodus slender or widened distally; exo- pod either with or without flagellum. Sternite 4 with rounded anterior projections; sternite 8 reduced, obscured, all sternal sutures interrupted. Male abdominal somites fused, usually 3-5 but may be other combination of somites. Chelipeds well-developed; pereiopod 5 absent. (After Schweitzer and Feldmann, 2001).

Family Trogloplacidae Guinot, 1986

Type genus. Trogloplax Guinot, 1986.

Included fossil genera. None; known only from freshwater environments from which the fossil record of Brachyura is poor.

Diagnosis. Carapace rounded, regions poorly defined; front straight with shallow medial notch, notch between front and supraorbital angle not apparent; upper orbital margin entire; anterolateral margin cristate, entire, or with spines; eyestalks short, eyes small; antennules folded completely into fosset; antenna placed in orbital hiatus. Buccal frame quadrate, merus of third maxilliped suboval, about as long as ischium.

Sternum very wide, all sternal sutures interrupted, sternite 8 clearly visible in ventral view; supplementary plate between sternites 7 and 8 covering penis; sterno-abdominal cavity deep; male abdominal somites 3-5 fused. Vulvae of females large, on extremity of sternal suture 5/6. Male gonopod 1 stout, sinuous, with simple apex; male gonopod 2 as long as or longer than gonopod 1, flagellum half as long as or slightly more than half its length. Fingers of chelae sometimes elongate and deflexed; dactyls of pereiopods 2-5 styliform with setae. (After Davie, 2002; Karasawa and Kato, 2003a).

Superfamily Goneplacoidea MacLeay, 1838, Incertae Sedis

Included fossil genus. Speocarcinus Stimpson, 1859 (also extant).

Discussion. The systematic position of Speocarcinus is uncertain. The genus was placed within the 'goneplacid' Pseudorhombilinae (Balss, 1957; Williams, 1984), whereas Hendrickx (1998) excluded it from his Pseudorhombilidae, maintained as a family by Martin and Davis (2001) and Schweitzer and 
Karasawa (2004). Števčić (2005) placed it within its own family Speocarcinidae Števčić, 2005. We are unable herein to resolve its placement but note that its fossil record extends into the Miocene (Tucker et al., 1994).

Superfamily Portunoidea Rafinesque, 1815

Included families. Carcineretidae Beurlen, 1930 (extinct); Geryonidae Colosi, 1923; Mathildellidae Karasawa and Kato, 2003a; Portunidae Rafinesque, 1815.

Occurrence. Cretaceous - Recent.

Diagnosis. Carapace hexagonal, subhexagonal, rectangular, or transversely ovate; carapace usually wider than long, usually widest at position of last anterolateral spine; flattened or weakly vaulted; regions poorly or moderately defined; anterolateral margins entire or with up to nine spines including outer orbital spine; front entire or spined; lobe on endopod of first maxilliped ('portunid lobe') sometimes present; chelipeds usually robust; last pair of pereiopods may have ovate dactyls; sternal sutures $4 / 5,5 / 6,6 / 7$, and 7/8 usually incomplete; sternite 8 usually visible in ventral view, with penial groove (Portunidae); male abdominal somites all free or 3-5 fused, if 3-5 fused, sutures may be visible; gonopod 1 strongly curved, with inflated, strongly hooked base.

Discussion. Glaessner (1969) and Guinot (1978) placed the Geryonidae within the Xanthoidea sensu lato. Since Manning and Holthuis (1981) suggested a Geryonidae and Portunidae relationship, several authors, Bowman and Abele (1982); Schweitzer and Feldmann (2000b); Martin and Davis (2001), have included the family within the Portunoidea. Števčić (in Martin and Davis, 2001) felt that the Geryonidae was closely related to the Goneplacidae sensu stricto and later placed both families within the Goneplacoidea (Števčić, 2005). Recently, Sakai (2004) placed the Geryonidae into the Xanthoidea sensu lato. Our analysis strongly supports the position of the Geryonidae within the Portunoidea.

The Portunoidea is traditionally arranged as less derived than the Xanthoidea sensu lato (Guinot, 1978; Williams, 1984; Martin and Davis, 2001). In some previous phylogenetic works, the Portunoidea were shown to be early-derived heterotremes, more so than the Xanthoidea sensu lato (Jamieson, 1991, 1993; Von Sternberg et al., 1999; Brösing, 2002; Wetzer et al., 2003), whereas Rice (1981, 1983), Števčić (1998), and Von Sternberg and Cumberlidge (2001) considered that the Portunoidea was a more advanced group than the Xanthoidea sensu lato. The present analysis suggests that the Portunidae together with Progeryon and Goneplacoidea is a more derived group than at least some of the xanthoid families. The fossil record supports this view with regard to the Portunidae and the Geryonidae, but it must be remembered that the Portunoidea as currently defined also embraces the extinct, Cretaceous Carcineretidae Beurlen, 1930. The Carcineretidae were not included in this analysis because they are known only from Cretaceous, Central and North American occurrences that are not sufficiently preserved to permit them to be useful within this analysis. The earliest known portunids are Danian in age (Schweitzer and Feldmann, 2000b), but their record does not become robust until the Eocene and later. The earliest known mathildellid is also Paleocene (Stenzel, 1944). The earliest record of the Geryonidae is from the Oligocene of Argentina or Europe (Glaessner, 1969; Schweitzer and Feldmann, 2000b). Thus, the Portunoidea in general is a lineage with later occurrences than the Xanthoidea sensu lato.

\section{Family Carcineretidae Beurlen, 1930}

Included fossil genera. Branchiocarcinus Vega et al., 1995; Carcineretes Withers, 1922; Longusorbis Richards, 1975; Mascaranada Vega and Feldmann, 1991; Ophthalmoplax Rathbun, 1935; Woodbinax Stenzel, 1952; questionably Cancrixantho Van Straelen, 1934, and Lithophylax A. Milne-Edwards and Brocchi, 1879.

Occurrence. Lower - Upper Cretaceous (Maastrichtian).

Diagnosis. Carapace quadrate or ovate, wider than long, with one or more transverse ridges; transverse ridges located on protogastric, hepatic, or branchial regions; front narrow, may be entire or with blunt spines; supraorbital margin long, with spines and notches; fronto-orbital width nearly equal to maxi- 
mum carapace width; posterior margin narrow; epibranchial region inflated, arcuate. Male sternum ovate, sternites 1-2 fused with no evidence of suture; sternal suture 2/3 a deep groove; sternal suture 3/4 incomplete; sternite 8 not visible in ventral view. Male abdomen narrow, somites apparently all free, entirely filling space between coxae of fifth pereiopods, reaching to about middle of somite 4 . Chelipeds more robust than pereiopods 2-5, manus may have keels on outer surface; propodi and dactyli of fourth and/or fifth pereiopods flattened into paddle-like shape (after Vega et al., 1997, fig. 4; Feldmann and Villamil, 2002; Schweitzer et al., 2003, fig. 15).

Discussion. The Carcineretidae traditionally has been placed within the Portunoidea based upon its possession of paddle-like dactyls on the fifth and sometimes fourth pereiopods. Members of the family also possess arcuate epibranchial regions and long orbits which are typical of many portunoids. However, many aspects of the Carcineretidae are quite abberrant as compared to other portunoids, such as the overall carapace shape, the extremely narrow front, and the ornate orbital margins. It is possible that the possession of paddle-like appendages, broad orbits, and arcuate epibranchial regions are examples of convergent evolution and that the Carcineretidae warrant their own superfamily. For example, members of the Matutidae De Haan, 1841, also possess paddle-like dactyls of the fifth pereiopods and are not portunoids, and some of the goneplacids have extremely broad orbits and are not portunoids. Testing this hypothesis, however, is beyond the scope of this paper and currently in preparation.

Family Geryonidae Colosi, 1923

Included fossil genera. Archaeogeryon Colosi, 1923; Archaeoplax Stimpson, 1863 (non Archaeoplax Alcock and Anderson 1894); Chaceon Manning and Holthuis, 1989 (also extant); questionably Coeloma A. Milne-Edwards, 1865 sensu lato.

\section{Occurrence. Oligocene - Recent}

Diagnosis. Carapace hexagonal, smooth or granular, wider than long, length about 80-85 percent maximum width; front spined, about 20 percent maximum carapace width; orbits directed forward, with or without orbital fissures, orbital hiatus completely closed, fronto-orbital width about half maximum carapace width in adults, may be considerably higher in juveniles; anterolateral margins with three to five spines; branchial regions with arcuate swelling anteriorly. Sternal sutures 4/5, 5/6, and 6/7 medially interrupted, 7/8 continuous or nearly so. Male abdominal somites 3-5 fused and immovable but with obvious sutures. Chelipeds heterochelous, much more robust than pereiopods 2-5; pereiopods 2-5 with long, pointed dactyli. Male gonopod 1 stout, curved, inflated basally, with simple apex; gonopod 2 long with long flagellum. (After Guinot, 1978; Schweitzer and Feldmann, 2000b; Davie, 2002).

Discussion. Geryon latifrons Van Straelen, 1936, is the only fossil species to have been referred to Geryon. Examination of a specimen of that species, R03977, by one of us (CES) in the Muséum National d'Histoire Naturelle in Paris suggests that it is probably the figured holotype (Van Straelen, 1936, pl. XXXIII, fig. 4), based upon the published description and measurements. However, the label did not designate the specimen as the type, and Van Straelen was often remiss about mentioning the repository of type material in his papers. In the introduction of the 1936 paper in which G. latifrons was described, he did mention the Muséum National d'Histoire Naturelle in Paris; thus, we believe that R03977 probably is the holotype.

Geryon latifrons is not a member of the Geryonidae based upon its extremely broad front (one-third maximum carapace width); broad fronto-orbital width (three-quarters maximum carapace width); and front and anterolateral margins with no or few spines, respectively. The species is similar is many respects to species of Chlinocephalus Ristori, 1886, including possession of a straight front with median notch; wide frontal width; fronto-orbital width about three-quarters maximum carapace width; anterolateral margin with two spines; arcuate epibranchial region; and depressed intestinal and posterior-most branchial regions. Geryon latifrons lacks the arcuate ridges on the dorsal carapace evident on Chlinocephalus (Garassino et al., 2004, fig. 16). Thus, we place G. latifrons in Chlinocephalus provisionally until type material can be reexamined to confirm placement.

Coeloma as currently defined embraces a broad range of dorsal carapace morphologies. Investigation 
of the genus is underway, which will resolve its status.

Family Mathildellidae Karasawa and Kato, 2003a

Included fossil genera. Branchioplax Rathbun, 1916; Tehuacana Stenzel, 1944.

\section{Occurrence. Paleocene - Recent.}

Diagnosis. Carapace wider than long, maximum carapace length about 80 percent maximum carapace width, widest about 45 percent the distance posteriorly, flattened, regions weakly defined; front straight with axial notch, frontal width about one-third maximum carapace width; supraorbital angle separated from frontal margin; orbit relatively small, with upper orbital fissures, fronto-orbital width about 60 percent maximum carapace width; anterolateral margins short, with five spines or lobes; posterolateral margins longer than anterolateral margins. Eyestalks short, antennular fossae broad laterally; merus of third maxilliped subquadrate, much longer than ischium. Sternum wide, usually with interrupted sutures except 7/8 which is continuous; sternite 7 without posterolateral prolongation, sternite 8 not visible in ventral view. Male abdominal somites usually all free, abdomen entirely filling space between coxae of fifth pereiopods. Chelipeds with dark fingers; dactyli of pereiopods 2-5 with corneous tips; dactyli of fifth pereiopods spatulate and with setae. Male gonopod 1 stout, curved, inflated basally, with simple apex; gonopod 2 long with long flagellum. (After Karasawa and Kato, 2003a).

Discussion. Števčić (2005) considered the Mathildellidae to be a tribe within the Geryonidae. Whereas our results show that the family is indeed related to the Geryonidae, and in fact, the Portunoidea, we retain it as a separate family due to the many distinctive differences between its members and the other portunoid families.

Family Portunidae Rafinesque, 1815

Included fossil genera. Acanthoportunus Schweitzer and Feldmann, 2002; Boschettia Busulini et al., 2003; Callinectes Stimpson, 1860 (also extant); Carcinus Leach, 1814 (also extant); Carupa Dana, 1851a (also extant); Charybdis De Haan, 1833 (also extant); Cicarnus Karasawa and Fudouji, 2000; Colneptunus Lőrenthey in Lőrenthey and Beurlen, 1929; Enoplonotus A. Milne-Edwards, 1860; Eocharybdis Beschin et al., 2002; Euphylax Stimpson, 1860 (also extant); Falsiportunites Collins and Jakobsen, 2003; Liocarcinus Stimpson, 1871 (also extant); Libystes A. MilneEdwards, 1867; Lissocarcinus Adams and White, 1848 (also extant); Lupocyclus Adams and White, 1848 (also extant); Macropipus Prestandrea, 1833 (also extant); Maeandricampus Schweitzer and Feldmann, 2002; Megokkos Schweitzer and Feldmann, 2000b; Minohellenus Karasawa, 1990; Miopipus Müller, 1984; Mioxaiva Müller, 1979; Necronectes A. Milne-Edwards, 1881; Neptocarcinus Lórenthey, 1898; Nogarolia Beschin et al., 1994; Ovalipes Rathbun, 1898 (also extant); Parathranites Miers, 1886 (also extant); Pleolobites Remy, 1960; Podophthalmus Lamarck, 1801 (also extant); Pororaria Glaessner, 1980; Portufuria Collins et al., 2005; Portumnus Leach, 1814 (also extant); Portunites Bell, 1858; Portunus Weber, 1795 (also extant); Proterocarcinus Feldmann et al., 1995; Psammocarcinus A. MilneEdwards, 1860; Psygmophthalmus Schweitzer et al., 2006; Rakosia Müller, 1984; Rhachiosoma Woodward, 1871; Scylla De Haan, 1833 (also extant); Sandomingia Rathbun, 1919; Saratunus Collins, Lee and Noad, 2003; Thalamita Latreille, 1829 (also extant).

\section{Occurrence. Paleocene - Recent.}

Diagnosis. Carapace hexagonal, transversely ovate, or subrectangular, usually wider than long; dorsoventrally flattened; regions usually poorly defined, epibranchial region arcuate, arching anteriorly (except Caphyrinae Paul'son, 1875 and Carupinae Paul'son, 1875); front straight and without spines (Carupinae) or lobate (Caphyrinae) or T-shaped (Podophthalminae Dana, 1851a) or with spines (Carcininae MacLeay, 1838; Polybiinae Ortmann, 1893; Portuninae Rafinesque, 1815; Psammocarcininae Beurlen, 1930; Thalamitinae Paul'son, 1875); orbits very wide (Podophthalminae) or small to moderate-sized (all other subfamilies), usually with fissures; anterolateral margin usually spined, with as many as nine spines, or entire (some Carupinae). Lobe on endopod of first maxilliped (so-called portunid lobe) usually present; chelipeds usually 
large, chelae often with keels and spines; fifth pereiopod usually with paddle-like dactylus (Caphyrinae; Polybiinae; Portuninae; Podophthalminae; Psammocarcininae; Thalamitinae) but may be styliform (Carcininae; Carupinae). Sternum broad, ovate; male thoracic sternite 8 visible ventrally; episternite 7 with well-developed posterolateral prolongation, penial groove present on male thoracic sternite 8; all sternal sutures incomplete except in some Carcininae. Male abdominal somites 3-5 usually fused.

Discussion. No attempt has been made to place the fossil genera within appropriate subfamilies; the Carcininae and the Polybiinae, for example, have been suggested to be polyphyletic (Von Sternberg and Cumberlidge, 2001; Schubart and Reuschel, 2005), and evaluation and revision of the Portunidae is beyond the scope of this paper.

\section{The fossil record and diversity of the Xanthoidea sensu lato}

At least 172 genera known in the fossil record within the Xanthoidea sensu lato are now assigned to the four superfamilies Carpilioidea, Xanthoidea sensu stricto, Eriphioidea, and Goneplacoidea. The familial arrangement of these genera is shown in Fig. 3 based upon the present new classification of the Xanthoidea sensu lato. Twenty-two extinct genera which were originally assigned to the Xanthidae sensu lato cannot be placed within any family.

The geologic ranges of the Palaeoxanthopsidae, Pilumnidae, Goneplacidae, and Hexapodidae all extend into the Late Cretaceous (Schweitzer et al., 2002; Schweitzer, 2003a, b; 2005a) (Figs. 3 and 4). The occurrences of these families suggest that the Carpilioidea (Clade A), Pilumnoidoidea (Clade B), Xanthoidea (Clade C), Eriphioidea (Clade D), Prog-

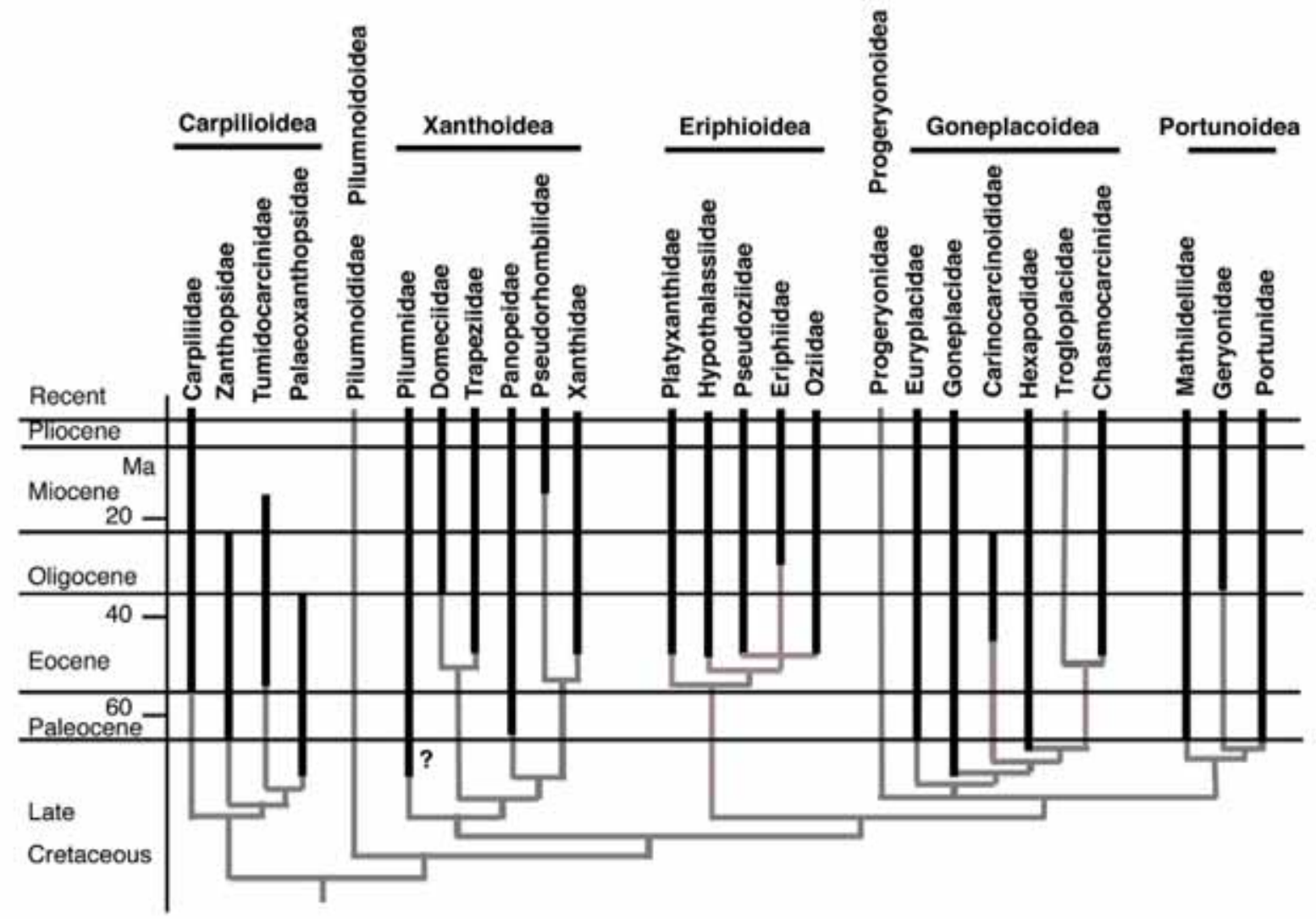

Fig. 4. Inferred cladogram, arranged to reflect occurrences of the families in the fossil record. Stratigraphic ranges are based on the oldest confirmed occurrence in each family. Ghost ranges are indicated as gray lines. 
eryonoidea (Clade E), Goneplacoidea (Clade F), and Portunoidea had diverged by the Late Cretaceous, although some of the other families have ghost ranges. The Pilumnoidoidea (Clade B), Progeryonoidea (Clade E), and the Trogloplacidae, lack fossil records and thus have very long ghost ranges.

Within the Carpilioidea (Clade A), the earliestknown family Palaeoxanthopsidae was well-established during the late Cretaceous and became extinct during the Eocene (Schweitzer, 2003a). The Tumidocarcinidae and Zanthopsidae each have rich Eocene fossil records, and both have last records during the Miocene (Schweitzer, 2003a; 2005a). The Carpiliidae was well established by Eocene time. Eocarpilius and Palaeocarpilius, both extinct genera, occurred in the Eocene and survived into the Miocene, and the only extant genus of the Carpiliidae Carpilius, appeared by the Miocene (Schweitzer, 2003a; 2005a).

Within the Xanthoidea (Clade C), the extant Pilumnidae and Panopeidae had first occurrences in the Cretaceous and Paleocene respectively and were well established by the Eocene, and both families are represented by numerous extinct genera at that time (Schweitzer, 2000; Schweitzer and Karasawa, 2004). The Trapeziidae and Xanthidae sensu stricto had appeared by the Eocene, the Domeciidae first appeared during the Oligocene, and the Pseudorhombilidae has its first record during the Miocene (Schweitzer, 2005b; Schweitzer and Karasawa, 2004). Most extinct genera within the Pilumnidae, Trapeziidae, Panopeidae, and Xanthidae did not survive beyond the Oligocene, but two pilumnids, Titanocarcinus and Lobonotus, and a panopeid, Laevicarcinus, survived into the Miocene (Schweitzer et al., 2002). A few extant genera, including the two panopeids Panopeus and Lophopanopeus and the trapeziid Tetralia, appeared during the Eocene. However, most extant genera of each family appeared during the Miocene, a pattern observed by Schweitzer (2001). The Xanthidae sensu stricto, with very few pre-Miocene records, has rich Miocene-Pleistocene fossil records, composed mostly of extant genera (Müller, 1984; Karasawa, 1993, 2000; Donovan et al., 2003); the family seems to have diversified during the Miocene (Fig. 3).

Within the Eriphioidea (Clade D), the Platyxanthidae, Pseudoziidae, and Oziidae each have Eocene fossil records. The Pseudoziidae embraces Eocene extinct genera, and the Platyxanthidae and Oziidae are represented in the Eocene by extant genera (Schweitzer, 2003a; 2005a). Eriphia, the sole genus of the Eriphiidae, makes its first occurrence in Oligocene rocks and is extant. The Hypothalassiidae contains only one extant genus, Hypothalassia, and has no fossil record; however, Titanocarcinus aculeatus Busulini et al., 1983, from the Eocene of Italy is quite similar to Hypothalassia and may represent a new monotypic genus within the family.

The Goneplacoidea first appeared during the Late Cretaceous, with representatives of the Hexapodidae and the Goneplacidae sensu stricto; both families are extant (Schweitzer and Feldmann, 2001; Schweitzer et al., 2002). The fossil record of both of these families became quite robust in the Eocene and remained so until the Recent (Schweitzer and Feldmann, 2001; Karasawa and Kato, 2003a). The Chasmocarcinidae made its first known appearance in the Eocene and is extant (Feldmann and Zinsmeister, 1984; Schweitzer and Feldmann, 2001). The Euryplacidae has had a robust fossil record since the Eocene and is extant; however, the Carinocarcinoididae, with only Eocene to Miocene records, has never been a robust family (Karasawa and Kato, 2003a). The Trogloplacidae has no fossil record; it is possible that the invasion of freshwater habitats in this lineage was an evolutionarily late event.

Guinot and Tavares (2001) restricted the genus Xanthosia Bell, 1863, and placed it and Etyus Leach in Mantell (1822), which had previously been assigned to the Xanthidae sensu lato by Schweitzer Hopkins et al. (1999), in a new podotreme family Etyidae Guinot and Tavares, 2001. However, they did not indicate the generic status of the remainder of the species that have been assigned to Xanthosia sensu lato. Caloxanthus A. Milne-Edwards, 1864, from the late Albian to Danian of U.S.A. and the North Atlantic traditionally has been placed within the Xanthidae sensu lato (Glaessner, 1969; Schweitzer et al., 2002). Wright and Collins (1972) and Jakobsen and Collins (1997) considered it as a member of the Carpiliidae; however, Guinot (1978) excluded Caloxanthus from that family. Sterna and abdomina preserved on specimens of C. americanus Rathbun, 1935, from the Cretaceous of Texas, housed in the collections at Kent State University, indicate that Caloxanthus should be referred to the Etyidae. Caloxanthus possesses the small size; hexagonal carapace; granular ornamentation; well-developed, complete orbits; 
narrow sternum that is completely covered by the female abdomen and nearly completely covered by the male abdomen; and free male and female abdominal somites that are diagnostic for the family. In addition, the abdominal somites of male and female Caloxanthus exhibit the distinctive feature of bearing marginal outlines so as to 'fit in' like puzzle pieces with the coxae of the pereiopods as seen in taxa of the Etyidae.

Bishop (1988) erected Xandaros to embrace Zanthopsis sternbergi Rathbun, 1926, and the genus has since been placed within the Xanthidae sensu lato. Xandaros is best placed within the Dromiidae De Haan, 1833, based upon its possession of a sulcate, triangular, bifid, front; orbits directed anterolaterally and with a swelling on the inner-orbital margin; and deep cervical and moderately defined branchio-cardiac grooves (Schweitzer et al., 2003).

Palaeoplax A. Milne-Edwards and Brocchi, 1879, from sub-Recent deposits of the Indo-Pacific, was referred to the Goneplacidae by Glaessner (1929) and later to Brachyura of uncertain systematic position (Glaessner, 1969). Examination of the illustration of the sole specimen (Desmarest, 1822, pl. XIII, fig. 9), strongly suggests that it is an eroded specimen of Macrophthalmus Latreille in Desmarest (1822). Pleistocene and Sub-Recent occurrences of Macrophthalmus are common in the Indo-Pacific and $\mathrm{Pa}-$ cific Ocean (Kesling, 1958; Idris, 1989; Karasawa and Mutsuoka, 1991; Morris and Collins, 1991; Karasawa et al., 1995; Schweitzer, Scott-Smith, and Ng, 2002); thus, synonymy of Palaeoplax with Macrophthalmus expands neither the geologic nor geographic range of the genus.

The extinct genera which are herein assigned to the Xanthoidea and Goneplacoidea incertae sedis, together with the remaining species of Xanthosia sensu lato, need to be evaluated in terms of familylevel placement based upon proxy characters of the carapace and examination of newly obtained material. Then, the ghost ranges of each family might become better resolved as will the timing of appearance of each lineage.

\section{Acknowledgements}

D. Guinot (Muséum national d’Histoire naturelle, Paris); R.B. Manning (late of Smithsonian Institution,
U.S. National Museum of Natural History, Washington, D.C.); J. Martin (Los Angeles County Museum, California); and P.K.L. Ng (National University of Singapore) each have provided helpful comments about the groups under discussion here; our thanks to them. We thank C. Beschin and A. De Angeli (Museo Civico 'G. Zannato', Italy); S. Calzada and P. Artal (Museo Geológico del Seminario de Barcelona, Spain); A. Kollar (Carnegie Museum of Natural History, Pittsburgh, Pennsylvania); T. Komai and H. Kato (Natural History Museum and Institute, Chiba, Japan); R. Lemaitre and W.C. Blow (Smithsonian Institution, U.S. National Museum of Natural History, Washington, D.C.); P. Müller (Hungarian Geological Survey, Hungary); T. Naruse (University of Ryukyus, Japan); A. Rage (Muséum national d'Histoire naturelle, Paris); and T. Sato (Kanagawa Prefectural Museum of Natural History, Japan) for loans from or access to collections in their institutions. J. Jagt, Natuurhistorisch Museum Maastricht, the Netherlands, provided important information about Titanocarcinus; our thanks to him. Sasagawa Scientific Research Grant from the Japan Science Society (no. 10-396M and 11-397M) and a Grant-in-Aid for Scientific Research from the Ministry of Education, Science, Sports and Culture (no. 10916027) supported fieldwork in the Ryukyus Islands to Karasawa. Travel for examination of Hungarian fossils was provided by a special fund from the Mizunami Municipal Government to Karasawa. Travel for collection of fossils in Croatia and Austria and to examine material deposited in museums in Budapest and Spain was provided by the Department of Research and Graduate Studies, Kent State University, to Schweitzer. Travel for examination of material in museums in Japan and in the United Kingdom was funded by National Geographic Society Grant 6265-98 to Schweitzer and Feldmann. NSF Grant INT 0003058 to Feldmann and Schweitzer funded collection of relevant material in Baja California Sur, México. Feldmann read an earlier draft of the manuscript; his suggestions are much appreciated. Very constructive reviews were provided by F.R. Schram, Langley, Washington, USA, and an anonymous reviewer; our thanks to them. M. Keatts, LAN Technician, Department of Geology, Kent State University, assisted with computer-related issues. The Inter-Library Loan service at Kent State University provided invaluable assistance in helping to locate old and obscure literature relevant to this study. 


\section{References}

Adams A, White A. 1848. Crustacea. In: Adams A. The Zoology of the Voyage of H. M. S. Samarang, 1843-1846: i-viii+1-66. London.

Alcock A. 1894. Natural history notes from the Indian Marine Survey Steamer 'Investigator'. Ser. II, No. 1. On the result of deep-sea dredging during the season of 1890-1891. Ann. Mag. Nat. Hist. (7) 13: 400-411.

Alcock A. 1898. The family Xanthidae: the Brachyura Cyclometopa, Part I: Materials for a carcinological fauna of India, No. 3. J. Asiatic Soc. Bengal 67: 67-233.

Alcock A. 1899. Natural history notes from the Royal Indian marine survey ship Investigator. Ser. III, No. 3. On some notable new or rare species of Crustacea. J. Asiatic Soc. Bengal 68: $111-119$.

Alcock A. 1900. Brachyura Catometopa or Grapsoidea: Materials for a carcinological fauna of India, No. 6. J. Asiatic Soc. Bengal 69: 279-456.

Alcock A, Anderson ARS. 1894. Natural History Notes from H. M. Indian Survey Steamer 'Investigator' Commander C.F. Oldham, R.N. Commanding. Ser. II, No. 14. An account of Recent Collections of Deep Sea Crustacea from the Bay of Bengal and Laccadive Sea. J. Asiatic Soc. Bengal 63: 141185.

Alcock A, Anderson ARS. 1899. Natural history notes from H. M. Royal Indian Marine Survey Ship 'Investigator', Commander T.H. Heming, R.N., commanding. Ser. III, No. 2, An account of the Deep-sea Crustacea dredged during the survey season of 1897-1898. Ann. Mag. Nat. Hist. (7) 3: 1-27, 278-292.

Balss H. 1932. Über einige systematisch interessante Xanthidae (Crustacea, Decapoda, Brachyura) der Harmsschen Reisen nach dem Sundaarchipel. Zeit. Wissensch. Zool. 142 (2): 510-519.

Balss H. 1933. Beiträge zur Kenntnis der Gattung Pilumnus (Crustacea, Dekapoda) und verwandter Gattungen. Capita Zool. 4 (3): 1-47.

Balss H. 1935. Die brachyuren Dekapoden der Reise MichaelsenHartmeyer nach Südwestaustralien 1905. Eine geographische Übersicht nebst Beschreibung einiger neuer Formen. Zool. Anz. 111 (1-2): 35-42.

Balss H. 1957. Decapoda. In: Dr. Bronns HG. Klassen und Ordnungen des Tierreichs Funfter Band 5, Abteilung 1, Buch 7: 1505-1672. Lieferung.

Bell T. 1858. A monograph of the fossil malacostracous Crustacea of Great Britain. Part I. Crustacea of the London Clay. London: Palaeontographical Society, 1-44.

Bell T. 1863. A monograph of the fossil malacostracous Crustacea of Great Britain. Part II. Of those found in the Greensand and Gault. London: Palaeontographical Society, 1-40.

Beschin C, De Angeli A. 2004. Nuovi Brachiuri Eocenici del Monti Lessini Vicentini (Italia Nordorientale). Studi e Ricerche Associazione Amici del Museo Civico 'G. Zannato', Montecchio Maggiore (Vicenza) 2004: 13-22.

Beschin C, Busulini A, De Angeli A, Tessier G. 1994. I crostacei Eocenici della Cava 'Boschetto' di Nogarole Vicentino (Vicenza B Italia settentrionale). Lavori Soc. Veneziana Sci. Nat. 19: 159-215.

Beschin C, Busulini A, De Angeli A, Tessier G. 2002. Aggiornamento ai crostacei eocenici di cava 'Main' di Arzignano.
Studi e Ricerche Associazione Amici del Museo Civico 'G. Zannato', Montecchio Maggiore (Vicenza) 2002: 7-28.

Beurlen K. 1930. Vergleichende Stammesgeschichte Grundlagen, Methoden, Probleme unter Besonderer Beruchsichtingung der hoheren Krebse. Fort. Geol. Palao. 8: 317-586.

Beurlen K. 1958. Contribução a paleontologia do Estado do Pará, Crostaceos decápodos da Formação Pirabas. Bol. Mus. Paraense Emilio Goeldi, n.s. (geol.) 5: 2-48.

Bishop GA. 1988. Two crabs, Xandaros sternbergi (Rathbun, 1926) n. gen., and Icriocarcinus xestos n. gen., n. sp., from the Late Cretaceous of San Diego County, California, USA, and Baja California Norte, Mexico. Trans. San Diego Soc. Nat. Hist. 21: 245-257.

Bittner A. 1875. Die brachyuren des Vicentinischen Tertiärgebirges. Denk. kais. Akad. Wiss. Wien 34: 63-103.

Bittner A. 1884. Beiträge zur Kenntnis tertiärer Brachyurenfaunen. Denk. kais. Akad. Wiss. Wien 48: 15-30.

Blow WC, Manning RB. 1996. Preliminary descriptions of 25 new decapod crustaceans from the middle Eocene of the Carolinas, U.S.A. Tulane Studies in Geol. Paleontol. 29: $1-26$.

Blow WC, Manning RB. 1997. A new genus, Martinetta, and two new species of xanthoid crabs from the Middle Eocene Santee Limestone of South Carolina. Tulane Stud. in Geol. Paleontol. 30: 171-180.

Böhm J. 1891. Die Kreidebildungen des Fürbergs und Sulzbergs bei Siegsdorf in Oberbayern. Palaeontographica 38: 1-106.

Böhm J. 1922. Arthropoda, Crustacea. In: Martin, K (ed). Die Fossilien von Java. I. Bd., 2. Abt. Samml. Geolog. Reichsmuseums Leiden, N.F. 2: 521-535.

Bouvier EL. 1922. Observations complémentaires sur les Crustacés décapodes (Abstraction faite les Carides) provenant des Campagnes de S.A.S. le Prince de Monaco. Résultats des Campagnes Scientifiques accomplies sur son yacht par Albert 1er Prince Souverain de Monaco 62: 1-106.

Bowman TE, Abele LG. 1982. Classification of the Recent Crustacea. In: Abele LG, ed. Systematics, the fossil record, and biogeography. The Biology of Crustacea Volume 1, Academic Press, New York, 1-27.

Bremer K. 1994. Branch support and tree stability. Cladistics 10: 295-304.

Broili F. 1904. Die Fauna Pachycardientuffe der Seiser Alp (mit Ausschluss der Gastropoden und Cephalopoden). Palaeontographica 50 (4-5): 145-227.

Brösing A. 2002. Die Megenstrukturen der Brachyura (Crustacea, Decapoda): Morphologie und phylogenetische Bedeutung (Unpublished doctoral thesis). Humboldt-Universität zu Berlin.

Busulini A, Tessier G, Visentin M. 1984. Titanocarcinus aculeatus nuova specie di Brachiuro dell'Eocene del Veneto (Crustacea, Decapoda). Lavori Soc. Veneziana Sci. Nat. 29: 107-117.

Busulini A, Tessier G, Beschin C, De Angeli A. 2003. Boschettia giampietroi, nouvo genere e specie di Portunidae (Crustacea, Decapoda) dell'Eocene medio della Valle del Chiampo (Vicenza, Italia settentrionale). Studi e Ricerche Associazione Amici del Museo Civico 'G. Zannato', Montecchio Maggiore (Vicenza) 2003: 13-18. 
Calman WT. 1909. On Decapod Crustacea from Christmas Island, collected by Dr. C.W. Andrews F.R.S., F.Z.S. Proc. Zool. Soc. London 1909: 703-713.

Carter J. 1898. A Contribution to the Palaeontology of the Decapod Crustacea of England. Quar. J. Geol. Soc. London 54: 15-44.

Casadío S, De Angeli A, Feldmann RM, Garassino A, Hetler JL, Parras A, Schweitzer CE. 2004. New decapod crustaceans (Thalassinidea, Brachyura) from the late Oligocene of Patagonia, Argentina. Ann. Carnegie Mus. 73: 85-107.

Castro P, Ng PKL, Ahyong ST. 2004. Phylogeny and systematics of the Trapeziidae Miers, 1886 (Crustacea: Brachyura), with the description of a new family. Zootaxa 643: 1-70.

Coelho PA, Coelho Filho PA. 1993. Proposta de classificação da família Xanthidae (Crustacea, Decapoda, Brachyura) através da taxonomia numérica. Rev. Brasiliera Zool. 10 (4): 559-580.

Collins JSH. 2002. A taxonomic review of British decapod Crustacea. Bull. Mizunami Fossil Mus. 29: 81-92.

Collins JSH, Jakobsen SL. 2003. New crabs (Crustacea, Decapoda) from the Eocene (Ypresian/Lutetian) Lillebælt Clay Formation of Jutland, Denmark. Bull. Mizunami Fossil Mus. 30: 63-96.

Collins JSH, Morris SF. 1978. New lower Tertiary crabs from Pakistan. Palaeontology 21: 957-981.

Collins JSH, Lee C, Noad J. 2003. Miocene and Pleistocene crabs (Crustacea, Decapoda) from Sabah and Sarawak. J. Syst. Palaeontol. 1: 187-226.

Collins JSH, Schulz BP, Jakobsen SL. 2005. First record of brachyuran decapods (Crustacea, Decapoda) from Fur Formation (early Eocene) of Murs and Fur Island. Bull. Mizunami Fossil Mus. 32: 17-22.

Colosi G. 1923. Una specie fossile de Gerionide (Decapodi Brachiuri). Bol. Soc. Natur. Napoli 37: 248-255.

Crosnier A. 1976. Données sur les Crustacés Décapodes capturés par M. Paul Guézé a l'île de La Réunion lors d'essais de pêche en eau profonde. In: Biologie marine et exploitation des resources de l'océan Indien occidental. Travaux et Documents ORSTOM 47: 225-254.

Crosnier A, Guinot D. 1969. Un nouveau crabe ouest-africain, Platychelonion planissimum gen. nov., sp. nov. Bull. Mus. Nat. Hist. Nat. Deuxieme Séries 41 (3): 725-730.

Dana JD. 1851a. On the classification of the Cancroidea. Am. J. Sci. Arts (2) 12: 121-131.

Dana JD. 1851b. Conspectus Crustaceorum quae in Orbis Terrarum Circumnavigatione, Carolo Wilkes e Classe Republicae Foederatae duce, lexit et descripsit. Pars VI. Am. J. Sci. Arts (2) 11: 268-274.

Dana JD. 1851c. On a new genus of Crustacea in the collection of the U.S. Exploring Expedition. Am. J. Sci. Arts 11: 223224.

Dana JD. 1851d. Crustacea Grapsoidea (Cyclometopa, Edwardsii): Conspectus Crustaceorum quae in Orbis Terrarum Circumnavigatione, Carolo Wilkes e Classe Republicae Foederatae duce, 8. Proc. Acad. Nat. Sci. Philadelphia 5: 247-254.

Dana JD. 1852. Crustacea Part I. In: United States Exploring Expedition during the Years 1838, 1839, 1840, 1841, 1842
Under the Command of Charles Wilkes, U.S.N. 13: 1-685. Philadelphia: C. Sherman.

Dana JD. 1853. A review of the classification of Crustacea, with reference to certain principles of classification. In: United States Exploring Expedition during the Years 1838, 1839, 1840, 1841, 1842 Under the Command of Charles Wilkes, U.S.N. 13: 1395-1592. Philadelphia: C. Sherman.

Davie PJF. 2002. Crustacea: Malacostraca: Eucarida (Part 2): Decapoda Anomura, Brachyura. In: Wells A, Houston WWK, eds. Zoological Catalogue of Australia 19.3B. Melbourne: CSIRO Publishing, 1-641.

Davie PJF, Ng PKL. 2000. Bountiana, a new genus for Eriphia norfolcensis Grant and McCulloch, 1907 (Crustacea: Brachyura: Eriphiidae). Mem. Queensland Mus. 45 (2): 267272.

Davie PJF, Guinot D. 1996. Two new freshwater crabs in Australocarcinus Davie, with remarks on Trogloplacinae Guinot and Goneplacidae MacLeay (Crustacea: Decapoda: Brachyura). Mem. Queensland Mus. 39 (2): 277-287.

De Haan W. 1833-1850. Crustacea. In: Von Siebold PF. Fauna Japonica sive descriptio animalium, quae in Itinere per Japoniam, Jussu et auspiciis superiorum, qui Summun in India Batava Imperium tenent, suscepto, annis 1823-1830 collegit, notis, observationibus et adumbrationibus illustravit. J. Müller: Lugduni-Batavorum (= Leiden), i-xvii + i-xxxi + ixxvi + 1-243.

De Man JG. 1904. Beschreibung einiger Brachyuren Krebse aus post-tertiären Schichten der Minahassa, Celebes. Samml. Geol. Reichsmus. Leiden (1) 7: 254-277.

Desmarest AG. 1822. Histoire Naturelle des Crustacés Fossiles. Les Crustacés Proprement Dits. F.G. Levrault: Paris, 67-154.

Desmarest AG. 1823. Crustacés Malacostracés. In: Dictionnaire des Sciences naturelles 28. F.G. Levrault et Le Normant: Strasbourg and Paris, 138-425.

Desmarest AG. 1825. Considérations génerales sur la Classe des Crustacés. Paris: F.G. Levrault, 1-446.

Doflein F. 1904. Brachyura. In: Wissenschaftliche Ergebnisse der Deutschen Tiefsee-Expedition auf dem Dampfer 'Valdivia' 1898-1899. Verlag von Gustav Fischer: Jena, : i-xiv, 1-314 + atlas.

Donovan SK, Portell RW, Collins JSH. 2003. Cretaceous and Cenozoic decapod crustaceans of Jamaica. Contr. Zool. 72 (2-3): 105-109.

D’Orbigny A. 1842. Voyage dans l'Amérique méridional,18261833 (III). Géologie et Paléontologie. Paris: Pitois-Levrault; Strasbourg: Levrault, 1-561.

D’Udekem d'Acoz C. 1999. Inventaire et distribution des crustacés décapodes de l'Atlantique nord-oriental, de la Méditerranée et des eaux continentales adjacentes au nord de $25^{\circ} \mathrm{N}$. Patrimoines naturels (M.N.H.N./S.P.N.) 40: 1-383.

Eydoux F, Souleyet LFA. 1842. Crustacés. In: Voyage autour du monde exécuté pendant les années 1836 et 1837 sur la corvette la Bonite, commandée par M. Vaillant, etc., Zoologie. Paris, 219-272.

Fabricius JC. 1793. Entomologia Systematica Emendata et Aucta. Secundum Classes, Ordines, Genera, Species, Adjectis Synonimis, Lois, Observationibus, Descriptionibus 2. Hafniae, i-viii + 1-519. 
Felder DL, Rabalais NN. 1986. The genera Chasmocarcinus Rathbun and Speocarcinus Stimpson on the Continental shelf of the Gulf of Mexico, with descriptions of two new species (Decapoda: Brachyura: Goneplacidae). J. Crust. Biol. 6: 547-575.

Feldmann RM. 1998. Parasitic castration of the crab, Tumidocarcinus giganteus Glaessner, from the Miocene of New Zealand: coevolution within the Crustacea. J. Paleontol. 72: 493-498.

Feldmann RM, Villamil T. 2002. A new carcineretid crab (Upper Turonian, Cretaceous) of Columbia. J. Paleontol. 76: 718-724.

Feldmann RM, Zinsmeister WJ. 1984. New fossil crabs (Decapoda: Brachyura) from the La Meseta Formation (Eocene) of Antarctica: paleogeographic and biogeographic implications. J. Paleontol. 58: 1046-1061.

Feldmann RM, Casadío, S, Chirino-Gálvez L, Aguirre-Urreta M. 1995. Fossil decapod crustaceans from the Jaguel and Roca Formations (Maastrichtian-Danian) of the Neuquén basin, Argentina. Paleontol. Soc. Mem. 43: 22 p.

Feldmann RM, Bice KL, Schweitzer-Hopkins C, Salva EW, Pickford K. 1998. Decapod crustaceans from the Eocene Castle Hayne Limestone, North Carolina: Paleoceanographic implications. Paleontol. Soc. Mem. 48: 28 p.

Fischer-Benzon $\mathbf{R}$ von. 1866. Über das relative Alter des FaxoeKalkes und über die in demselben vorkommenden Anomuren und Brachyuren. Kiel.

Forskål P. 1775. Descriptiones Animalium, Avium, Amphibiorum, Piscium, Insectorum, Vermium, quae in itinere orientali observavit Petrus Forskål Mölleri: Hauniae (= Copenhagen), 1-19+ i-xxxiv + 1-164.

Fraaye RHB. 1996. A new Tethyan migrant: Cretachlorodius enciensis n. gen., n. sp. (Crustacea, Decapoda), from the Maastrichtian type area. J. Paleontol. 70: 463-465.

Galil B, Takeda M. 1986. Resurrection of the genus Jonesius and the establishment of a new genus: Commensal crabs associated with corals from the Indo-Pacific Ocean. Bull. Nat. Sci. Mus. Tokyo, Ser. A 12: 163-171.

Galil B, Takeda M. 1988. A revision of the genus Glabropilumnus (Crustacea, Decapoda, Brachyura). Bull. Nat. Sci. Mus., Tokyo, Ser. A 14: 67-90.

Garassino A, De Angeli A, Gallo LM, Pasini G. 2004. Brachyuran and anomuran fauna from the Cenozoic of Piedmont (NW Italy). Atti Soc. Italiana di Sci. Nat., Mus. Civ. Storia Nat. Milano 145 (II): 251-281.

Gistel J. 1848. Naturgeschichte des Thierreiches für höhere Schulen bearbeitet. Stuttgart, i-xvi + 1-210.

Glaessner MF. 1929. Crustacea Decapoda. In: Pompeckj JF, ed. Fossilium Catalogus I: Animalia Pt. 41. Berlin: W. Junk, 1-464.

Glaessner MF. 1933. New Tertiary crabs in the collection of the British Museum. Ann. Mag. Nat. Hist., ser. 10 12: 128.

Glaessner MF. 1960. The fossil decapod Crustacea of New Zealand and the evolution of the order Decapoda. New Zealand Geol. Survey Palaeontol. Bull. 31: 63 p.

Glaessner MF. 1969. Decapoda, In: Moore RC, ed. Treatise on Invertebrate Paleontology, Part R, Arthropoda 4. Geological
Society of America and University of Kansas Press, Lawrence, R399-R533, R626-R628.

Glaessner MF. 1980. New Cretaceous and Tertiary crabs (Crustacea: Brachyura) from Australia and New Zealand. Trans. Royal Soc. of South Australia 104: 171-192.

Glaessner MF, Secretan S. 1987. Crabes (Crustacea Brachyura) de l'Éocène du Sulaiman Range (Pakistan). Ann. de Paléo. (Vert.-Invert.) 73: 273-288.

Gray JE. 1831. Description of a New Genus, and Some Undescribed Species of Crustacea. In: Gray JE. The Zoological Miscellany: 39-40. London.

Guinot D. 1967a. Recherches préliminaires sur les groupements naturels chez les Crustacés Décapodes Brachyoures. II. Les anciens genres Micropanope Stimpson et Medaeus Dana. Bull. Mus. Nat. Hist. Nat. Paris, Deuxieme Série, 39 (2): 345374.

Guinot D. 1967b. Recherches préliminaires sur les groupements naturels chez les Crustacés Décapodes Brachyoures. IV. Observations sur quelques genres de Xanthidae. Bull. Mus. Nat. Hist. Nat. Paris, Deuxieme Série, 39 (4): 695-727.

Guinot D. 1969. Recherches préliminaries sur les groupements naturels chez les Crustacés, Décapodes, Brachyoures. VII. Les Goneplacidae (suite et fin). Bull. Mus. Nat. Hist. Nat. Paris, Deuxieme Série, 41 (3): 688-724.

Guinot D. 1970 [1971]. Recherches préliminaries sur les groupements naturels chez les Crustacés, Décapodes, Brachyoures. VIII. Synthèse et bibliographie. Bull. Mus. Nat. Hist. Nat. Paris, Deuxieme Série, 42 (5): 1063-1090.

Guinot D. 1976. Constitution de quelques groupes naturels chez les Crustacés Décapodes Brachyoures. I. La superfamille des Bellioidea Dana et trois sous-familles de Xanthidae (Polydectinae Dana, Trichiinae De Haan, Actaeinae Alcock). Mém. Mus. Nat. Hist. Nat. Paris (A) 97: 1-308.

Guinot D. 1977. Propositions pour une nouvelle classification des Crustacés Décapodes Brachyoures. Comptes Rendus hebd. séances Acad. Sci. (Paris) (D) 285: 1049-1052.

Guinot D. 1978. Principes d'une classification évolutive des Crustacés Décapodes Brachyoures. Bull. Biol. France Belgique 112 (3): 209-292.

Guinot D. 1986. Description d'un Crabe cavernicole aveugle de Nouvelle-Bretagne (Papouasie Nouvelle-Guinée), Trogloplax joliverti gen. nov. sp. nov., et éstablissement d'une sous-famille nouvelle, Trogloplacinae subfam. nov. Comptes Rendus hebd. séances Acad. Sci. (Paris) (3) 303: 307-312.

Guinot D. 1988. Les crabes des sources hydrothermales de la dorsale du Pacifique oriental (campagne Biocyarise, 1984). Oceanologica Acta, 1988. Actes du Coll. Hydrothermalisme, Biol. Écol., Paris, 4-7 Novembre 1985: 109-118.

Guinot D, Macpherson E. 1987. Révision du genre Pilumnoides Lucas, 1844, avec description de quatre espèces nouvelles et création de Pilumnoidinae subfam. nov. (Crustacea Decapoda Brachyura). Bull. Mus. Nat. Hist. Nat. Paris, Quatrieme Série 9 (A, no. 1): 211-247.

Guinot D, Richer de Forges B. 1981. Crabes de profondeur, nouveaux ou rares, de Indo-Pacifique (Crustacea, Decapoda, Brachyura) (Deuxième partie). Bull. Mus. Nat. Hist. Nat. Paris (4A) 4: 227-260. 
Guinot D, Tavares M. 2001. Une nouvelle famille de crabes du Crustacés et al notion de Podotremata Guinot, 1977 (Crustacea, Decapoda, Brachyura). Zoosytema 23: 507-546.

Guinot D, Hurtado LA, Vrijenhoek R. 2002. New genus and species of brachyuran crab from the southern East Pacific Rise (Crustacea Decapoda Brachyura Bythograeidae). Comptes Rendus Biol. 325 (11): 1143-1152.

Heller C. 1861. Beiträge zur Crustaceen-Fauna des rothen Meeres. Sitz. Math.-Physik. Klasse Bay. Akad. Wiss. München 43: 297-374.

Hendrickx ME. 1998. A new genus and species of Goneplacidlike brachyuran crab (Crustacea: Decapoda) from the Gulf of California, Mexico, and a proposal for the use of the family Pseudorhombilidae Alcock, 1900. Proc. Biol. Soc. Washington 111: 634-644.

Herbst JFW. 1782-1804. Versuch einer Naturgeschichte der Krabben und Krebse. Berlin and Stralsund, 1-515.

Hilgendorf F. 1879. Die von Herrn W. Peters in Mozambique gesammelten Crustaceen, bearbeitet von Herrn Dr. F. Hilgendorf. Monatsbericht. dt. Akad. Wiss. Berlin 1878: 782-851.

Holthuis LB. 1987. Necora, a new genus of European swimming crabs (Crustacea Decapoda, Portunidae) and its type species, Cancer puber L., 1767. Zool. Meded. Leiden 61: 1-14.

Hu C-H, Tao H-J. 1996. Crustacean fossils of Taiwan. Taipei, Taiwan, 1-228.

Idris MB. 1989. Fossil crabs of Sabah. Warta Geologi (= Newsletter of the Geological Society of Malaysia) 15 (5): 207-213.

International Commission on Zoological Nomenclature. 1999. International Code of Zoological Nomenclature. International Trust for Zoological Nomenclature.

Jakobsen SL, Collins JSH. 1997. New middle Danian species of anomurans and brachyuran crabs from Fakse, Denmark. Bull. Geol. Soc. Denmark 44: 89-100.

Jamieson BGM. 1991. Ultrastructure and phylogeny of crustacean spermatozoa. Mem. Queensland Mus. 31: 225-234.

Jamieson BGM. 1993. Spermatological evidence for the Taxonomic status of Trapezia (Crustacea: Brachyura: Heterotremata). Mem. Queensland Mus. 33: 225-234.

Karasawa H. 1990. Decapod crustaceans from the Miocene Mizunami Group, central Japan, Part 2 Section Oxyrhyncha, Cancridea and Brachyrhyncha. Bull. Mizunami Fossil Mus. 17: 1-33.

Karasawa H. 1993. Cenozoic decapod Crustacea from southwest Japan. Bull. Mizunami Fossil Mus. 20: 1-92.

Karasawa H. 2000. Coral-associated decapod Crustacea from the Pliocene Daito Limestone Formation and Pleistocene Ryukyu Group, Ryukyu Islands, Japan. Bull. Mizunami Fossil Mus. 27: 167-189.

Karasawa H, Fudouji Y. 2000. Palaeogene decapod Crustacea from the Kishima and Okinoshima Groups, Kyushu, Japan. Paleontol. Res. 4 (4): 239-253.

Karasawa H, Kato H. 2001. The systematic status of the genus Miosesarma Karasawa, 1989 with a phylogenetic analysis within the family Grapsidae and a review of fossil records (Crustacea: Decapoda: Brachyura). Paleontol. Res. 5 (4): 259-275.

Karasawa H, Kato H. 2003a. The family Goneplacidae MacLeay, 1838 (Crustacea: Decapoda: Brachyura): systematics, phylogeny, and fossil records. Paleontol. Res. 7 (2): 129151.

Karasawa H, Kato H. 2003b. The phylogeny, systematics and fossil record of the Goneplacidae MacLeay (Crustacea, Decapoda, Brachyura) revisited. Contr. Zool. Mesozoic and Cenozoic Decapod Crustaceans 72 (2-3): 147-152.

Karasawa H, Mutsuoka K. 1991. Fossil decapod crustaceans from the Holocene deposits of Katahama, Tahara-cho, Aichi Peninsula, central Japan. Sci. Rep. Toyohashi Mus. Nat. Hist. 1: $1-12$.

Karasawa H, Schweitzer CE. 2004. Revision of the genus Glyphithyreus Reuss, 1859 (Crustacea, Decapoda, Brachyura: Xanthoidea) and recognition of a new genus. Paleontol. Res. 8 (3): 143-154.

Karasawa H, Nohara T, Shimoji K. 1995. Decapod Crustacea from the Ryukyu Group (Pleistocene) of Okinawa-jima, Japan. Bull. Mizunami Fossil Mus. 22: 127-132.

Kesling RV. 1958. Fossil crabs from Guam. Contr. Mus. Paleontol., University of Michigan XIV (14): 207-263.

Koh SK, Ng PKL. 2000. A revision of the spiny crabs of the genus Hypothalassia Gistel, 1848 (Crustacea: Decapoda: Brachyura: Eriphiidae). Raffles Bull. Zool. 48 (1): 123-141.

Kossmann R. 1877. Malacostraca (1: Theil Brachyura). In: Kossmann R. Zool. Ergebnisse einer Reise in die Küstengebiete des Roten Meeres: 1-66. Leipzig.

Kossmann R. 1878. Kurze Notizen über einige neue Crustaceen sowie über neue Fundorte einiger bereits beschriebenen. Arch. Naturgesch. 44 (1): 251-258.

Krøyer H. 1837. Geryon tridens, en ny Krabbe. Naturhistorisk Tidsskrift 1: 10-21.

Lamarck JBPA. 1801. Systême des animaux sans vertèbres, ou tableau général des classes, des ordres et des genres de ces animaux; présentant leurs caractères essentiels et leur distribution, d'après la considération de leurs rapports naturels et de leur organisation, et suivant l'arrangement établi dans les galeries du Muséum d'Hist. Naturelle, parmi leurs dépouilles conservées; précédé du discours d'ouverture du cours de zoologie, donné dans le Muséum national d'Histoire naturelle l'an 8 de la République. Paris, i-viii +432.

Latreille PA. 1802-1803. Histoire naturelle, générale et particulière, des crustacés et des insectes 3. Dufart: Paris, 1-468.

Latreille PA. 1817. Nouveau dictionnaire d'histoire naturelle, appliquée aux arts, à l'agriculture,à l'economie rurale et domestique,à la médecine, etc. 10. Déterville: Paris, 1-404.

Latreille PA. 1828. Encyclopédie Méthodique: Histoire Naturelle, Entomologie, ou Histoire Naturelle des Crustacés, des Arachnides, et des Insectes 10: 345-832.

Latreille PA. 1829. Les Crustacés, les Arachnides et les insectes, distributes en familles naturelles. Le Règne Animal, distribué d'après son organization, pour servir de base à l'histoire naturelle des animaux et d'introduction à l'anatomie comparee. $2^{\text {nd }}$ ed. 4. Paris, 1-584.

Laurie RD. 1906. Report on the Brachyura collected by Professor Herdman, at Ceylon, in 1902. In: Herdman WA. Report to the Government of Ceylon on the Pearl Oyster Fisheries of the Gulf of Manaar with supplementary reports upon the Marine Biology of Ceylon by other Naturalists, part 5, suppl. Rep. 40: 349-432. 
Leach WE. 1814. Crustaceology. In: Brewster D. The Edinburgh Encyclopaedia 7: 383-437.

Leach WE. 1815. A tabular view of the external characters of four classes of animals, which Linnée arranged under Insecta, with the distribution of the genera composing three of these classes into orders, and description of several new genera and species. Trans. Linnean Soc. London 11: 306-400.

Likharev B. 1917. The remains of crabs from the lower-Tertiary deposits of Donetz-Basin. Jahrb. der Russischen Paläontol. Gesellsch. (Petrograd) 1: 13-24.

Linnaeus C. 1758: Systema Naturae per Regna Tria Naturae, Secundum Classes, Ordines, Genera, Species, cum Characteribus, Differentiis, Synonymis, Locis, Tomus 1. Laurentii Salvii, Stockholm, i-iii + 1-823.

Linnaeus C. 1767. Systema Naturae per Regna tria Naturae, secundum classes, ordines, genera, species, cum characteribus, differentiis, synonymis, locis. (edit. 12), 1 (2): 5331327.

Lockington WN. 1877. Remarks on the Crustacea of the Pacific coast, with descriptions of some new species. Proc. Cal. Acad. Sci. 7: 28-36.

Lőrenthey E. 1898. Über die Brachyuren der paläontologischen Sammulung des bayerischen Staates. Természetrajzi Füzetek 21: 134-152.

Lőrenthey E. 1902. Neue Beiträge zur tertiären Decapodenfauna Ungarns. Math. Natur. Bericht. Ungarn 18: 98-120.

Lőrenthey E, Beurlen K. 1929. Die Fossilen Dekapoden der Länder der ungarischen Krone. Geologica Hungarica, Series Palaeontologica 3: 1-420.

MacLeay WS. 1838. On the brachyurous decapod Crustacea brought from the Cape by Dr. Smith. In: Illustrations of the Annulosa of South Africa; being a Portion of the Objects of Natural History Chiefly Collected during an Expedition into the Interior of South Africa, under the Direction of Dr. Andrew Smith, in the Years 1834, 1835, and 1836; Fitted out by 'The Cape of Good Hope Association for Exploring Central Africa'. Smith, Elder, and Company: London, 53-71.

Maddison WP, Maddison DL. 2001. MacClade version 4.06. Sunderland, Massachusetts: Sinauer Associates.

Manning RB, Holthuis LB. 1981. West African Brachyuran crabs. Smithson. Contr. Zool. 306: 379 p.

Manning RB, Holthuis LB. 1989. Two new genera and nine new species of geryonid crabs (Crustacea, Decapoda, Geryonidae). Proc. Biol. Soc. Washington 102: 50-77.

Mantell GA. 1822. The Fossils of the South Downs; or Illustrations of the Geology of Sussex. London, England, 1-327.

Martin JW, Abele LG. 1986. Notes on male gonopod morphology in the brachyuran crab family Panopeidae Ortmann, 1893, sensu Guinot (1978) (Decapoda). Crustaceana 50: 182-198.

Martin JW, Davis GB. 2001. An updated classification of the recent Crustacea. Nat. Hist. Mus. Los Angeles Co., Sci. Series 39: $1-124$.

Martin K. 1879-1880. Die Tertiärschichten auf Java. Nach den Entdeckungen von Junghuhn bearbeitet: 127-132.

Martins-Neto RG. 2001. Review of some Crustacea (Isopoda and Decapoda) from Brazilian deposits (Paleozoic, Mesozoic, and Cenozoic) with descriptions of new taxa. Acta Geol. Leopoldensia XXXIV (52/53): 237-254.
McCoy F. 1849. On the classification of some British fossil Crustacea, with notices on the new forms in the University collection at Cambridge. Ann. Mag. Nat. Hist., series 2, 4 (21): 161-179.

Meyer $\mathbf{H}$ von. 1863. Tertiaere Decapoden aus den Alpen, von Oeningen und dem Taunus. Palaeontographica 10: 147-178.

Miers EJ. 1879. On a collection of Crustacea made by Capt. H.C. St. John, R.N., in the Corean and Japanese Seas. Part. 1. Podophthalmia. With an Appendix By Capt. H.C. St. John. Proc. Zool. Soc. London 1879: 18-61.

Miers EJ. 1886. Report on the Brachyura collected H.M.S. Challenger during the Years 1873-1876. Reports of the Scientific Results of the Voyage of H.M.S. Challenger during the Years 1873-1876, Zool. 17: 1-362.

Milne-Edwards A. 1860. Historie des Crustacés podophthalmaires fossiles. Ann. Sci. Nat., Zool. (4) 13: 129-293.

Milne-Edwards A. 1862-65. Monographie des Crustacés fossiles de la famille Cancériens. Ann. Sci. Nat., Zool. (4) 18 [1862]: 31-85; 20 [1863]: 273-324; (5) 1 [1864]: 31-88; 3 [1865]: 297-351.

Milne-Edwards A. 1867. Descriptions de quelques espèces nouvelles de Crustacés Brachyures. Ann. Soc. Entomol. France 4: 263-288.

Milne-Edwards A. 1869. Description d'un nouveau genre de Crustacé Cancérien. Ann. Soc. Entomol. France 9: 167-169.

Milne-Edwards A. 1879. Études sur les Xiphosures et les Crustacés de la région mexicaine. In: Missions scientifiques au Mexique et dans l'Amérique Centrale. Recherches Zoologique de la Faunae Amérique Centrale et Mexique, part 5 1: 1-368.

Milne-Edwards A. 1880. Études preliminaries sur les Crustacés, liére Partie. In: Reports on the Results of Dredging under the Supervision of Alexander Agassiz, in the Gulf of Mexico, and in the Caribbean Sea, 1877, 1878, 1879, by the U. S. Coast Survey Steamer Blake Lieut.-Commander C.D. Sigsbee, U.S.N., and Commander J.R. Bartlett, U.S.N., Commanding. Bull. Mus. Comparative Zool. Harvard College 8 : 1-68.

Milne-Edwards A. 1881. Note sur quelques Cruscacés fossiles des environs de Biarritz. Ann. Sci. Géol. France 11 (2): pls. 21-22.

Milne-Edwards A, Brocchi P. 1879. Note sur quelques Crustacés fossiles appartenant au groupe des Macrophthalmiens. Bull. Soc. Philomathique Paris 3: 113-117.

Milne-Edwards H. 1834-1840. Histoire naturelle des Crustacés, comprenant l'anatomie, la physiologie et la classification de ces animaux 1 (1834): i-xxxv + 1-468; 2 (1837): 1-532; 3 (1840): 1-638, Atlas: 1-32. Paris.

Milne-Edwards H. 1852. De la famille des ocypodides (Ocypodidae). Second Mémoire. Observations sur les affinités zoologiques et la classification naturelle des crustacés. Ann. Sci. Nat., Zool., Série 3 18: 109-166.

Milne-Edwards H, Lucas H. 1843. Crustacés. In: D’Orbigny A. Voyage dans l'Amerique méridionale (le Brésil, la république orientale de l'Uruguay, la république Argentine, la Patagonie, la république du Chili, la république de Bolivia, la république du Pérou), ex ut pendant les années 1826, 1827, 1828, 1829, 1830, 1831, 1832 et 1833, 6 (1): 1-37. P. Bertrand, Paris. 
Morris SF, Collins JSH. 1991. Neogene crabs from Brunei, Sabah and Sarawak. Bull. British Mus. Nat. Hist. (Geol.) 47: 1-33.

Müller P. 1979. Decapoda (Crustacea) fauna a budapesti miocénbol (5). Földtani Közlöny 108: 272-312.

Müller P. 1984. Decapod Crustacea from the Badenian. Geologica Hungarica, Series Palaeontographica 42: 317 p.

Müller P, Collins JSH. 1991. Late Eocene coral-associated decapods (Crustacea) from Hungary. Contr. Tertiary Quaternary Geol. 28: 47-92.

Ng PKL. 1998. Crabs. In: Carpenter KE, Niem VH, eds., The living marine resources of the western Central Pacific. Volume 2. Cephalopods, crustaceans, holothurians, and sharks. Rome: Food and Agriculture Organization of the United Nations, 1046-1155.

Ng PKL. 2000. The deep-water swimming crabs of the genus Benthochascon (Decapoda: Brachyura: Portunidae), with description of a new genus for the American B. schmitti. $J$. Crust. Biol., special number 2: 310-324.

Ng PKL, Clark PF. 2000. The Indo-Pacific Pilumnidae XII. On the familial placement of Chlorodiella bidentata (Nobili, 1901) and Tanaocheles stenochilus Kropp, 1984 using adult and larval characters with the establishment of a new subfamily, Tanaochelinae (Crustacea: Decapoda: Brachyura). J. Nat. Hist. 34: 207-245.

Ng PKL, Guinot D. 1999. On a new species of deep-water crab of the genus Progeryon (Decapoda, Brachyura, Geryonidae) from Hawaii. Crustaceana 72: 685-692.

Ng PKL, Liao LM. 2002. On a new species of Euryozius Miers, 1886 (Crustacea: Decapoda: Brachyura: Pseudoziidae) from the Philippines, with notes on the taxonomy of the genus. Proc. Biol. Soc. Washington 115: 585-593.

Ng PKL, Rodriguez G. 1986. New records of Mimilambrus wileyi Williams, 1979 (Crustacea: Decapoda: Brachyura), with notes on the systematics of the Mimilambridae Williams, 1979 and Parthenopoidea MacLeay, 1838 sensu Guinot, 1978. Proc. Biol. Soc. Washington 99: 88-99.

Ng PKL, Wang C-H. 1994. Notes on the enigmatic genus Pseudozius Dana, 1851 (Crustacea, Decapoda, Brachyura). J. Taiwan Mus. 47 (1): 83-99.

Ng PKL, Wang C-H, Ho P-H, Shih H-T. 2001. An annotated checklist of brachyuran crabs from Taiwan (Crustacea: Decapoda). Nat. Taiwan Mus. Sp. Pub. Ser. 11: 86 p.

Nobili MG. 1906. Diagnoses preliminaires de 34 especes et variés nouvelles et de 2 genres nouveaux de Decapodes de la Mer Rouge. Bull. Mus. Nat. Hist. Nat., Paris, Premiere Séries 11 (6): 393-411.

Odhner T. 1925. Monographierte Gattungen der Krabben-familie Xanthidae. I. Göteborgs Kungliga Vetenskaps-och Vitterhets-Samhalles Handlingar 29 (1): 1-92.

Ortmann A. 1893. Die Decapoden-Krebse des Strassburger Museums, VII. Theil. Abtheilung: Brachyura (Brachyura genuina Boas). II. Unterabtheilung: Cancroidea, 1. Gruppe: Cyclometopa. Zool. Jahr., Abt. Syst., Geog., Biol. Thiere 7: 411-495.

Ortmann A. 1896. Das System der Decapoden-Krebse. Zool. Jahr., Abt. Syst., Geog., Biol. Thiere 9: 409-453.

Paul'son OM. 1875. Podophthlmata I Edriophthalmata (Cumacea) Part I. In: Izledovaniya Rakoobraznykh Krasnago Morya s Zamekami Otnositel'no Rakoobraznykh Drugikhv Morie, i-xiv, 1-144 p., pls. 1-21. Kul'zhenko: Kiev. [Reprinted 1961. Studies on Crustacea of the Red Sea with notes regarding other seas. Part I. Podophthalmata and Edriophthalmata (Cumacea). The Israel Program for Scientific Translations, Jerusalem, 1-164.

Pennant T. 1777. Decapoda. In: The British Zoology 4: 1-20. London.

Pereyra Lago R. 1988. Larval development of Spiroplax spiralis (Barnard, 1950) (Brachyura: Hexapodidae) in the Laboratory; the systematic position of the family on the basis of larval morphology. J. Crust. Biol. 8: 576-596.

Poeppig E. 1836. Crustacea Chilensia nova aut minus nota descripsit. Arch. Natur. 2 (1): 133-145.

Poore GCB. 2004. Marine Decapod Crustacea of Southern Australia. A Guide to Identification. Melbourne: Museum Victoria, i-ix, 1-574.

Portell RW, Collins JSH. 2004. Decapod crustaceans of the lower Miocene Montpelier Formation, White Limestone Group of Jamaica. Cain. Res. 3: 109-126.

Poupin J. 1996. Crustacea Decapoda of French Polynesia (Astacidea, Palinura, Anomura, Brachyura). Atoll Res. Bull. 442: $1-114$.

Poupin J. 2003. Crustacea Decapoda and Stomatopoda of Easter Island and Surrounding Areas. A documented checklist with historical overview and biogeographic comments. Atoll Res. Bull. 500: 1-50.

Prestandrea N. 1833. Su di alcumi nuovi crustacei dei mari di Messina. Effemeridi Scientifiche e Letterarie per La Sicilia 1833: 3-14.

Prestandrea N. 1839. Descrizione di due nuovi Crustacei dei Mari di Messina. Atti Accad. Gioenia Sci. Nat. Catania (1) 14: 131-136.

Rafinesque SCS. 1815. Analyse de la nature, ou tableau de l'univers et des corps organisés. L'Imprimerie de Jean Barravecchia: Palermo, Italy, 1-224.

Rathbun MJ. 1897. A revision of the nomenclature of the Brachyura. Proc. Biol. Soc. Washington 11: 153-167.

Rathbun MJ. 1898. The Brachyura of the biological expedition to the Florida Keys and the Bahamas in 1893. Bull. Lab. Nat. Hist. State Univ. Iowa 4: 250-294.

Rathbun MJ. 1914. A new genus and some new species of crabs of the family Goneplacidae. Proc. US Nat. Mus. 48: 137-154.

Rathbun MJ. 1916. Description of a new genus and species of fossil crab from Port Townsend, Washington. Am. J. Sci. 41: 344-346.

Rathbun MJ. 1918. The grapsoid crabs of America. Bull. US Nat. Mus. 97: 1-461.

Rathbun MJ. 1919. West Indian Tertiary decapod crustaceans. Carnegie Inst. Washington Pub. 291: 159-184.

Rathbun MJ. 1926. The fossil stalk-eyed Crustacea of the Pacific slope of North America. Bull. US Nat. Mus. 138: 155 p.

Rathbun MJ. 1929. A new crab from the Eocene of Florida. Proc. US Nat. Mus. 75 (15): 4 p.

Rathbun MJ. 1931. New crabs from the Gulf of Mexico. J. Washington Acad. Sci. 21: 125-128.

Rathbun MJ. 1935. Fossil Crustacea of the Atlantic and Gulf Coastal Plain. GSA. Sp. Paper 2: 160 p. 
Rathbun MJ. 1945. Decapod Crustacea. In: Ladd HS and Hoffmeister JE (eds). Geology of Lau, Fiji, Bernice Pauahi Bishop Mus. Bull. 181: 373-383.

Remy J-M. 1960. Études paléontologiques et géologiques sur les Falaises de Fresco (Côte d'Ivoire) 2. Crustacés. Ann. Fac. Sci., Univ. de Dakar 5: 55-64.

Remy J-M, Tessier F. 1954. Décapodes nouveaux de la partie ouest de Sénégal. Bull. Soc. Géol. France (6) 4: 185-191.

Reuss R. 1859. Zur Kenntnis fossiler Krabben. Denks. Kais. Akad. Wiss. Wien, Math.-Natur. Classe 17: 1-59.

Rice AL. 1981. Crab zoeae and brachyuran classification: a re-appraisal. Bull. British Mus. Nat. Hist. (Zool.) 40 (5): $287-$ 296.

Rice AL. 1983. Zoeal evidence for brachyuran phylogeny. In: Schram FR (ed). Crustacean Phylogeny, Crustacean Issues 1. Rotterdam: A.A. Balkema, 313-329.

Richards BC. 1975. Longusorbis cuniculosus: a new genus and species of Upper Cretaceous crab with comments on the Spray Formation at Shelter Point, Vancouver Island, British Columbia. Can. J. Earth Sci. 12: 1850-1863.

Ristori, G. 1886. I Crostacei Brachyiuri e Anomuri del Pliocene Italiano. Boll. Soc. Geol. Italiana 5: 93-119.

Rodriguez G. 1992. The freshwater crabs of America. Family Trichodactylidae and supplement to the family Psudothelphusidae. Faune Tropicale 31: 1-192.

Say T. 1817-1818. An account of the Crustacea of the United States. J. Acad. Nat. Sc. Philadelphia 1 (1-2) 1817: 57-63, 97-101, 155-160, 161-169, pl. 4; 1818: 235-253, 313-316, 317-319, 374-380, 381-401, 423-441.

Sakai K. (editor) 2004. Crabs of Japan. World Biodiversity Database CD-ROM Series. Paris: Biodiversity Center of ETI, Amsterdam and UNESCO-Publishing.

Sakai T. 1974. Notes from the carcinological fauna of Japan (V). Res. Crust. 6: 86-012.

Sakai T. 1978. Decapod Crustacea from the Emperor Seamount Chain. Res. Crust. (Supplement) 8: 1-39.

Samouelle G. 1819. The entomologist's useful compendium, or an introduction to the knowledge of British insects. London, 1-486.

Sankarankutty C. 1962. On Decapoda Brachyura from the Andaman and Nicobar Islands. 2. Family Xanthidae. J. Mar. Biol. Assoc. India 4 (1): 121-150.

Schubart CD, Reuschel S. 2005. Molecular phylogenetic relationships of cancroid and portunoid crabs (Decapoda: Brachyura) do not reflect current taxonomy. Book of Abstracts, Sixth International Crustacean Congress, Glasgow, Scotland, UK, 18-22 July, 2005: 7.

Schubart CD, Neigle JE, Felder DL. 2000. Use of the mitochondrial 16S rDNA gene for phylogenetic and population studies of Crustacea. Crust. Issues 12: 817-830.

Schweitzer CE. 2000. Tertiary Xanthoidea (Crustacea: Decapoda: Brachyura) from the west coast of North America. J. Crust. Biol. 20: 715-742.

Schweitzer CE. 2001. Paleobiogeography of Cretaceous and Tertiary decapod crustaceans of the North Pacific Ocean. $J$. Paleontol. 75: 808-826.

Schweitzer CE. 2003a. Utility of proxy characters for classification of fossils: an example from the fossil Xanthoidea
(Crustacea: Decapoda: Brachyura). J. Paleontol. 77: 911932.

Schweitzer CE. 2003b. Progress on the fossil Xanthoidea MacLeay, 1838 (Decapoda, Brachyura). Contr. Zool. 72 (2-3): 181-186.

Schweitzer CE. 2005a. The genus Xanthilites Bell, 1858 and a new xanthoid family (Crustacea: Decapoda: Brachyura: Xanthoidea): new hypotheses on the origin of the Xanthoidea MacLeay, 1838. J. Paleontol. 79: 277-295.

Schweitzer CE. 2005b. The Trapeziidae and Domeciidae (Decapoda: Brachyura: Xanthoidea) in the fossil record and a new Eocene genus from Baja California Sur, Mexico. J. Crust. Biol. 25 (4): 625-636.

Schweitzer CE, Feldmann RM. 2000a. New species of calappid crabs from western North America and reconsideration of the Calappidae sensu lato. J. Paleontol. 74: 230-246.

Schweitzer CE, Feldmann RM. 2000b. New fossil portunids from Washington, USA, and Argentina, and a re-evaluation of generic and family relationships within the Portunoidea Rafinesque, 1815 (Decapoda: Brachyura). J. Paleontol. 74: 636-653.

Schweitzer CE, Feldmann RM. 2001. Differentiation of the fossil Hexapodidae Miers, 1886 (Decapoda: Brachyura) from similar forms. J. Paleontol. 75: 330-345.

Schweitzer CE, Feldmann RM. 2002. New Eocene decapods (Thalassinidea and Brachyura) from Southern California. $J$. Crust. Biol. 22: 938-967.

Schweitzer CE, Karasawa H. 2004. Revision of Amydrocarcinus and Palaeograpsus (Decapoda: Brachyura: Xanthoidea) with definition of three new genera. Paleontol. Res. 8 (1): 71-86.

Schweitzer CE, Ćosović V, Feldmann RM. 2005. Harpactocarcinus from the Eocene of Istria, Croatia, and the paleoecology of the Zanthopsidae Via, 1959 (Crustacea: Decapoda: Brachyura). J. Paleontol. 79 (4): 663-669.

Schweitzer CE, Feldmann RM, Gingerich PD. 2004. New Decapoda (Crustacea) from the middle and late Eocene of Pakistan and a revision of Lobonotus A. Milne Edwards, 1864. Contr. Mus. Paleontol., University of Michigan 31 (4): 89-118.

Schweitzer CE, Scott-Smith PR, Ng PKL. 2002. New occurrences of fossil decapod crustaceans (Thalassinidea, Brachyura) from late Pleistocene deposits of Guam, United States Territory. Bul. Mizunami Fossil Mus. 29: 25-49.

Schweitzer CE, Feldmann RM, Gonzáles-Barba G, Vega FJ. 2002. New crabs from the Eocene and Oligocene of Baja California Sur, Mexico and an assessment of the evolutionary and paleobiogeographic implications of Mexican fossil decapods. Paleontol. Soc. Mem. 76: 43 p.

Schweitzer CE, Iturralde-Vinent M, Hetler JL, Velez-Juarbe J. 2006. Oligocene and Miocene decapods (Thalassinidea and Brachyura) from the Caribbean. Ann. Carnegie Mus. 75: 111-136.

Schweitzer CE, Feldmann RM, Tucker AB, Berglund RE. 2000. Eocene decapod crustaceans from Pulali Point, Washington. Ann. Carnegie Mus. 69: 27-67.

Schweitzer CE, Feldmann RM, Fam JM, Hessin WA, Hetrick SW, Nyborg TG, Ross RLM. 2003. Cretaceous and Eocene 
decapod crustaceans from southern Vancouver Island, British Columbia, Canada. NRC Research Press: Ottawa, Ontario, 1-66.

Schweitzer-Hopkins CE, Salva EW, Feldmann RM. 1999. Reevaluation of the genus Xanthosia Bell, 1863 (Decapoda: Brachyura: Xanthidae) and description of two new species from the Cretaceous of Texas. J. Paleontol. 73: 77-90.

Serène R. 1964. Redescription du genre Magasthesius Rathbun et definition des Chasmocarcininae, nouvelle sous-famille des Goneplacidae (Decapoda, Brachyura). Crustaceana 7: 175-187.

Serène R. 1984. Crustacés Décapodes Brachyoures de l'Ocean Indien occidental et de la Mer Rouge. Xanthoidea: Xanthidae et Trapeziidae. Addendum: Carpiliidae et Menippidae by Alain Crosnier. Faune Tropicale 24: 1-399.

Shaw G, Nodder FP. 1803. Vivarium Naturae, sive rerum naturalium, variae et vividae icons, ad ipsam naturam depictae et descriptae. Crustacea. The Naturalist's Miscellany, or Coloured Figures of Natural Objects, Drawn and Described Immediately from Nature 15: pls. 589-612. London.

Smith AI. 1869. Notice of the Crustacea collected by Prof. C.F. Hartt on the coast of Brazil in 1867, list of the described species of Brazilian Podophthalmia. Trans. Connecticut Acad. Arts Sci. 2: 1-41.

Smith AI. 1879. The stalk-eyed crustaceans of the Atlantic coast of North America north of Cape Cod. Trans. Connecticut Acad. Arts Sci. 5 (1): 27-136.

Spears T, Abele LG, Kim W. 1992. The monophyly of brachyuran crabs: a phylogenetic study based on 18S rRNA. Syst. Biol. 41 (4): 446-461.

Stenzel HB. 1944. A new Paleogene catometope crab from Texas, Tehuacana tehuacana. J. Paleontol. 18: 546-549.

Stenzel HB. 1952. Decapod crustaceans from the Woodbine Formation of Texas. USGS Prof. Paper 242: 212-217.

Števčić Z. 1991. Note on some rare and aberrant Australian crabs. Beagle, Rec. Northern Territory Mus. Arts Sci. 8: 121-134.

Števčić Z. 1995. Brachyuran systematics and the position of the family Raninidae reconsidered. Arthropoda Selecta 4 (3/4): 27-36.

Števčić Z. 1998. Evolutionary arrangement of the brachyuran families together with a checklist. Periodicum Biologorum 100 (1): 101-104.

Števčić Z. 2005. The reclassification of brachyuran crabs (Crustacea: Decapoda: Brachyura). Fauna Croatica 14, supplement 1: 159 pp.

Stimpson W. 1858. Prodromus descriptionis animalium evertebratorum, quae in Expeditione ad Oceanum Pacificum Septentrionalem, a Republica Federata missa, Cadwaladaro Ringgold et Johanne Rodgers Ducibus, observavit et descripsit W. Stimpson. Pars. V. Crustacea Ocypodoidea. Proc. Acad. Nat. Sci., Philadelphia 10: 93-110.

Stimpson W. 1859. Notes on North American Crustacea. No. I. Ann. Lyceum Nat. Hist. New York 7: 49-93.

Stimpson W. 1860. Notes on North American Crustacea, in the Museum of the Smithsonian Institution. No. II. Ann. Lyceum Nat. Hist. New York 7: 177-246.

Stimpson W. 1863. On the fossil Crab of Gay Head. Boston J. Nat. Hist. 7 (1859-63): 583-589.
Stimpson W. 1871. Preliminary report on the Crustacea dredged in the Gulf Stream in the Straits of Florida, by L.F. de Pourtales, Assist. U.S. Coast Survey. Bull. Mus. Comparative Zool. Harvard College 2: 109-160.

Swofford DL. 1999. PAUP*: Phylogenetic Analysis Using Parsimony, Version $4 b$. Champaign, Illinois: Illinois Natural History Survey.

Takeda M, Miyake S. 1969. A small collection of crabs from New Zealand. OHMU 2: 157-193.

Tessier G, Beschin C, Busuluni A, De Angeli A. 1999. Nuovi Brachiuri Eocenici nella cava 'Main' di Arzignano (Vicenza - Italia settentrionale). Lavori Soc. Veneziana Sci. Nat. 24: 93-105.

Todd JA, Collins JSH. 2005. Neogene and Quaternary crabs (Crustacea, Decapoda) collected from Costa Rica and Panama by members of the Panama Paleontology Project. Bull. Mizunami Fossil Mus. 32: 53-85.

Tucker AB, Feldmann RM. 1990. Fossil decapod crustaceans from the lower Tertiary of the Prince William Sound region, Gulf of Alaska. J. Paleontol. 64: 409-427.

Tucker AB, Feldmann RM, Powell CL, II. 1994. Speocarcinus berglundi n. sp. (Decapoda: Brachyura), a new crab from the Imperial Formation (Late Miocene-Late Pliocene) of southern California. J. Paleontol. 68: 800-807.

Tudge CC, Jamieson BGM, Segonzac M, Guinot D. 1998. Spermatozoal ultrastructure in three species of hydrothermal vent crab, in the genera Bythograea, Austinograea and Segonzacia (Decapoda, Brachyura, Bythograeidae). Inv. Reproduct. Dev. 34 (1): 13-23.

Türkay M. 1983. Georgeoplax, new genus for Litocheira glabra Baker, 1906 (Crustacea: Decapoda: Brachyura). Australian Mus. Mem. 18: 101-105.

Van Straelen V. 1933. Sur des Crustacés Décapodes Cénozoiques du Venezuela. Bull. Mus. Royal Hist. Nat. Belgique 9: 1-14.

Van Straelen V. 1934. Contribution à l'étude des crustacés décapodes fossiles de la Catalogne. Géol. Pays Catalans 3: 1-6.

Van Straelen V. 1936. Sur quelques crabes du Sahélien moyen des environs d’Oran (Algérie). Bull. Soc. Geol. France 6: 473-480.

Vázquez-Bader AR, Gracia A. 1991. Euphrosynoplax campechiensis, new species (Crustacea, Decapoda, Brachyura, Goneplacidae) from the continental shelf of southwestern Gulf of Mexico. Bull. Mus. Nat. Hist. Nat., Paris, série 4 13: 433-438.

Vega FJ, Feldmann RM. 1991. Fossil crabs (Crustacea: Decapoda) from the Maastrichtian Difunta Group, northeastern Mexico. Ann. Carnegie Mus. 60: 163-177.

Vega FJ, Feldmann RM, Sour-Tovar F. 1995. Fossil crabs (Crustacea: Decapoda) from the Late Cretaceous Cárdenas Formation, East-Central Mexico. J. Paleontol. 69: 340350.

Vega FJ, Feldmann RM, Ocampo AC, Pope KO. 1997. A new species of Late Cretaceous crab (Brachyura: Carcineretidae) from Albion Island, Belize. J. Paleontol. 71: 615-620.

Vega FJ, Feldmann RM, García-Barrera P, Filkorn H, Pimentel F, Avendaño J. 2001. Maastrichtian Crustacea 
(Brachyura: Decapoda) from the Ocozocuautla Formation in Chiapas, southeast México. J. Paleontol. 75: 319-329.

Vega FJ, Cosma T, Coutiño MA, Feldmann RM, Nyborg TG, Schweitzer CE, Waugh DA. 2001. New middle Eocene decapods (Crustacea) from Chiapas, México. J. Paleontol. 75: 929-946.

Vía L. 1959. Décapodos fósiles del Eoceno español. Bol. Inst. Geol. Min. de España 70: 331-402.

Vía L. 1966. Pinnixa (Palaeopinnixa) mytilicola, nuevo braquiuro fósil, en el mioceno marino del Vallé (Barcelona). Acta Geol. Hispanica 1: 1-4.

Vinassa de Regny II, P. 1897. Contribuzioni alla conoscenza dei Crostacei fossili italiani. Simoniellia quiricensis n.g.n.sp. del Pliocene di San Quirico d’Orcia. Rivista Italiana di Paleontologia 3 (5-6): 19-24.

Von Sternberg R, Cumberlidge N. 2001. Notes on the position of the freshwater crabs within the brachyrhynchan Eubrachyura (Crustacea: Decapoda: Brachyura). Hydrobiologia 449: 21-39.

Von Sternberg R, Cumberlidge N, Rodriquez G. 1999. On the marine sister groups of the freshwater crabs (Crustacea: Decapoda: Brachyura). J. Zool. Syst. Evol. Res. 37: 19-38.

Ward M. 1942. Notes on the Crustacea of the Desjardins Museum, Mauritius Institute, with descriptions of new genera and species. Bull. Mauritius Inst., Port Louis 2 (2): 49-113.

Weber F. 1795. Nomenclator entomologicus secundum Entomologiam Systematicam ill. Fabricii adjectis speciebus recens detectis et varietatibus. Kiel and Hamburg, 1-171.

Wetzer R, Martin JW, Trautwein SE. 2003. Phylogenetic relationships within the coral crab genus Carpilius (Brachyura, Xanthoidea, Carpiliidae) and of the Carpiliidae to other xanthoid crab families based on molecular sequence data. Mol. Phylogenet. Evol. 27: 410-421.
White A. 1852. Descriptions of some new species of Annulosa. In: Macgillivray J. Narrative of the voyage of H.M.S. Rattlesnake during the years 1846-1850 2: 387-395. London.

Williams A. 1980. A new crab family from the vicinity of submarine thermal vents on the Galapagos Rift (Crustacea: Decapoda: Brachyura). Proc. Biol. Soc. Washington 93: 443-472.

Williams A. 1984. Shrimps, Lobsters, and Crabs of the Atlantic Coast of the Eastern United States, Maine to Florida. Smithsonian Institution Press, Washington, D.C., 1-550.

Withers TH. 1922. Eocene brachyurous decapod Crustacea from Nigeria. Ann. Mag. Nat. Hist. 9 (10): 467-472.

Withers T. H. 1924. Eocene brachyurous decapod Crustacea from Nigeria. Ann. Mag. Nat. Hist. series 9 13: 94-97.

Withers TH. 1928. New Cretaceous crabs from England and Syria. Ann. Mag. Nat. Hist. 10 (2): 457-461.

Wood-Mason J. 1892. Crustacea. Part I. In: Illustrations of the Zoology of the Royal Indian marine Surveying Steamer 'Investigator' pls. 1-5. Calcutta.

Woodward H. 1867. On a new genus of shore-crab, Goniocypoda Edwardsi, from the lower Eocene of Hampshire. Geol. Mag. 4: 529-531.

Woodward H. 1871. Notes on some new crustaceans from the lower Eocene of Portsmouth. Q. J. Geol. Soc. London Pt 1 27: 90-92.

Wright CW, Collins JSH. 1972. British Cretaceous Crabs. Palaeont. Soc. Monograph 126 (533): 1-113.

Received: 29 August 2005

Accepted: 8 May 2006 
